Historic, Archive Document

Do not assume content reflects current scientific knowledge, policies, or practices. 
I! 


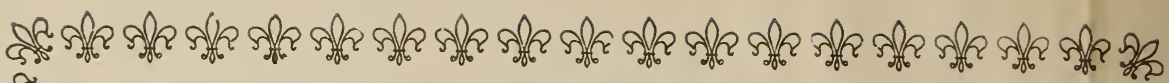

爱

हैं

造

爱

हैं

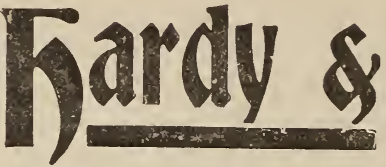

Bucchanan,

है

跣

岳

WHOLESALE AND RETAIL

GROCHRS AND

PROVISION MERCHANTS.

急

犗

हैं

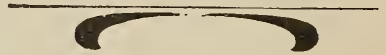

爱

害

IT isn't the big profits, on small sales we're after, Wut small profits on big sales. Now, this is the policy of our business, and if it works well for us है it surely must for the consumer. That has been our past है 17 years' experience in Winnipeg.

है Therefore we can save you money in anything you \& want in the grocery or provision line, either in large cr है small quantities, as well as pay the farmers the highest fo prices for their products at

爱

$\frac{8}{6}$

要

趋

है

223 MARKET SQUARE, TELEPHONE 593.

483, 485 NOTRE DAME AVE., TELEPHONE 266.

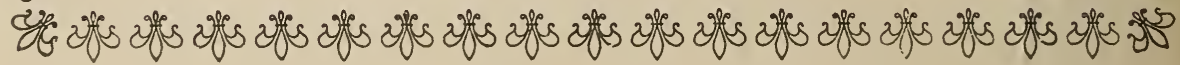




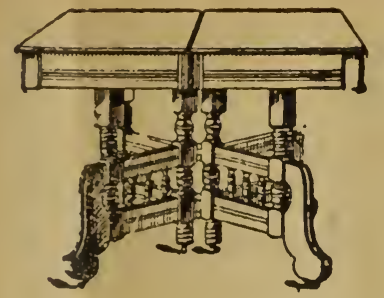

FREE * * *

OUR BIG ILLUSTRATED FURNITURE CAT. ALOGUE-mailed to your address. Send us yous name.

\section{DON'T BUY * * *}

Any Furniture till you get a copy. You will then know what good honest Furniture can be bought for.

MAIL ORDERS HAVE OUR BEET ATTENTION.

Scott Furniture Company, THE wIDE ATAKR house, Scott Furniture Company, 276 Main Street, WINNIPEG, MAN

The Old Reliable Clothing Man-

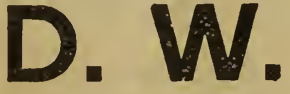

564 MAIN STREET,

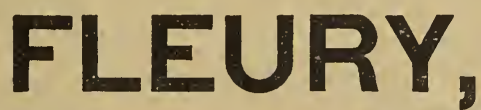

MINNIPEG, MAN.

Is where you can get the BEST VAI, OES in

Men's and Boys' Clothing, Gents Furnishings, HATS, CAPS, FUR COATS, EtC.

Opposite Hotel Brunswick,

(Next door to my old stand of 1882.)

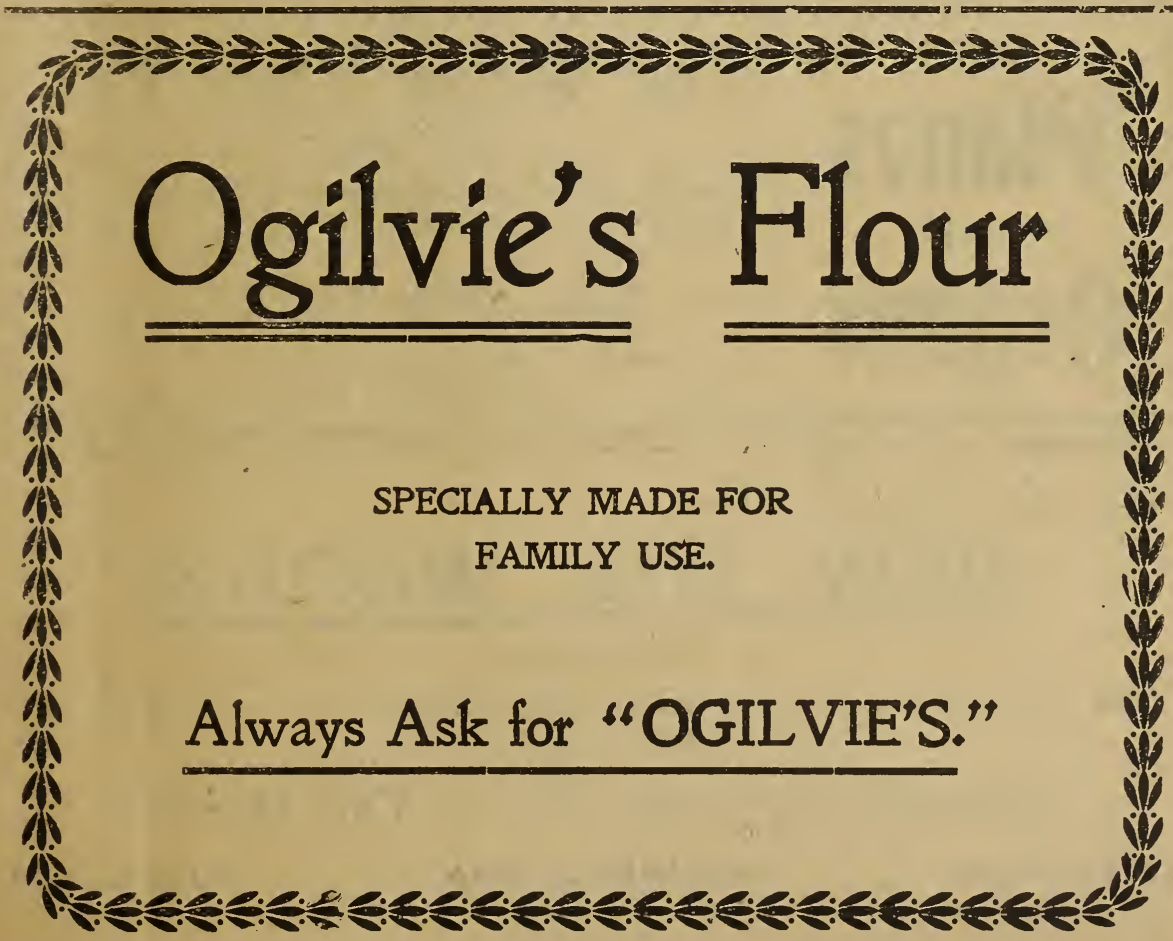




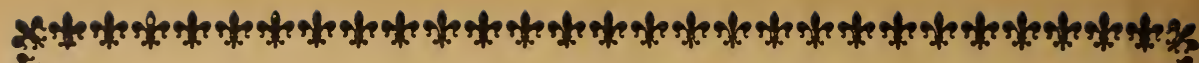

है

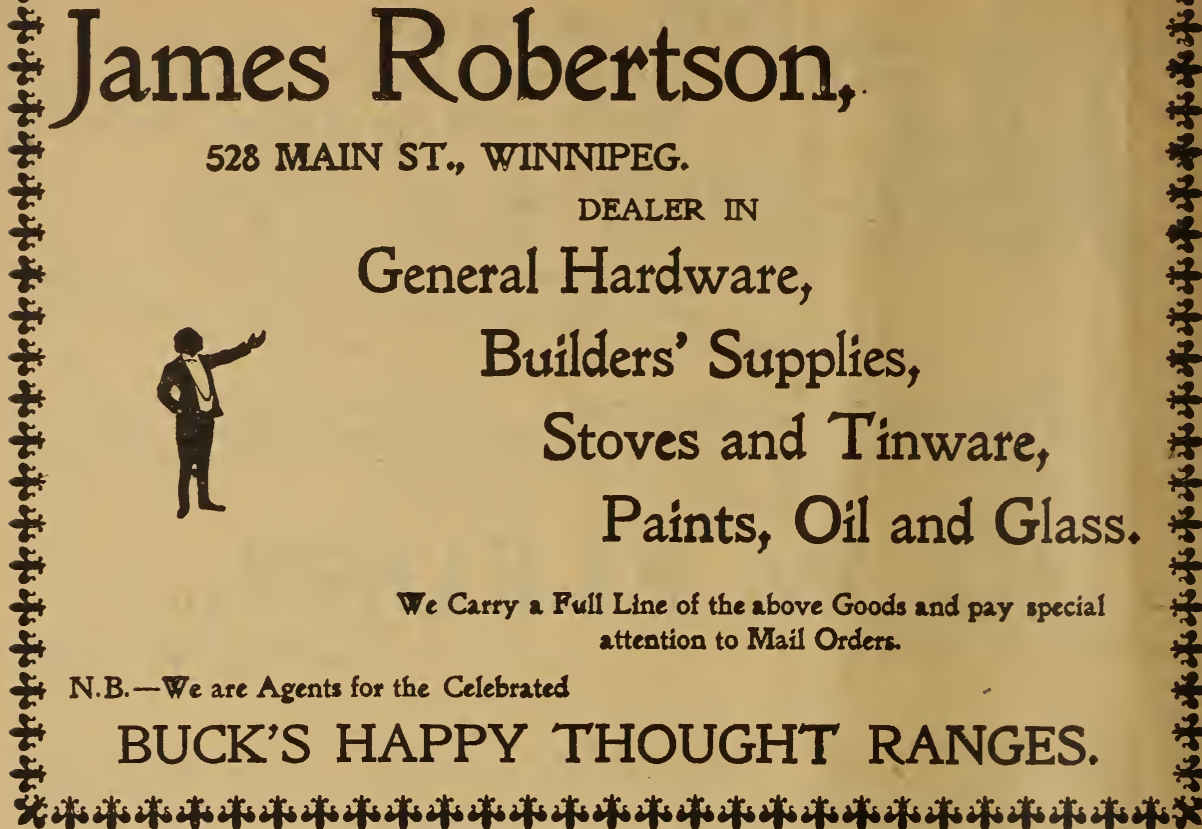

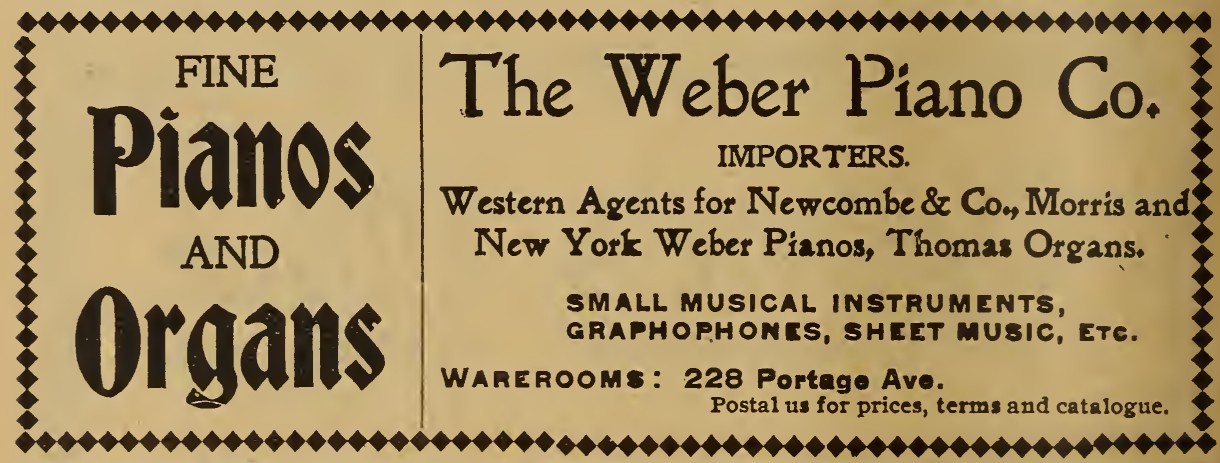

Have You Heard of the

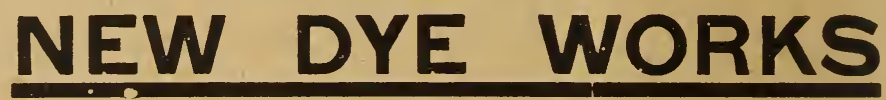

The most up-to-date Dyeing and Cleaning establishment west of Toronto. Country orders promptly attended to.

The Great Eastern Steam Dye Works, 


\section{Established} 1885 . Our Terms are Strictly
Cash with Order.
As the seed season is only of a few months' duration, we would impress on you the advantage of sending in your orders early. By so doing you will greatly facilitate their execution, and also insure greater accuracy and attention.

Remember, we send Free of Postage all Packets, Ounces and $\frac{1}{1}$-lbs., but for anything over that the purchaser MUST send at the rate of $4 \mathrm{c}$. per $\mathrm{lb}$. for postage, otherwise we will be compelled to deduct that amount from the seed ordered.

Pounds.-When ordered at pound rates, FOUR CENTS per $1 \mathrm{~b}$. must be added for postage, otherwise it will be deducted from the amount, by reducing the quantity ordered.

Bags.-To every order for one quarter bushel or upwards, to the amount of two bushels, 25 cents must be added for a new bag in which to ship.

How to Send Money.-All orders or communications should be mailed to our address, Winnipeg, Manitoba. The money must always accompany the order, and can be sent at our risk by P.O. Money Order or Registered Letter. The cost of a registered letter to our address is only 5 cents; money orders for $\$ 4$ or less, 2 cents; $\$ 1$ up to $\$ 10,5$ cents; $\$ 10$ up to $\$ 20$, 10 cents; $\$ 20$ up to $\$ 40,15$ cents. It it unsaie to send currency in ordinary letters. If currency is sent by express, the charges should be prepaid, and if local checks are used, 25 cents must be added to cover cost of collection.
Sign Your Name.-It frequently occurs that we receive letters containing money and orders, which we cannot fill, because the sender has failed to sign his name. Again, the P. O. address is frequently omitted, and the postmark being blurred, we are unable to fill the order, no matter how much we may desire to do so. Use our Order Sheet and Envelope in all cases where you can, fill out the blank and sign your name and you will have no cause to censure us.

Guarantee:- Complaints made that seeds are not good should quite as often be attributed to other causes as to the quality of the seeds. There are hundreds of contingencies continually arising to prevent the best seeds always giving satisfaction, such as sowing too deep, too shallow, in too wet or dry soil, insects of every description destroying the plants as scor. as, or before, they appear; wet weather, cold weather, frosts, chemical changes in the seeds induced by temperature, et:. For the above reasons it is impracticable to guarantee seeds under all circumstances, and while we exercise the greatest care to supply every article true to name, and of the very best quality, and believe our seeds to be the purest and best to be found, we wish it to be distinctly uncierstood that we sell no seeds with any warranty, express or implied, and we will not be in any way responsible for the crop.

\section{VALUABLE TABLE.
Quantity of Seed Requisite to Produce a Given Number of Plants and Sow an Acre.} Quantity Beans, dwarf, $1 \frac{1}{2}$ pints to 100 foot row....13 bus. Beet, garden, 1 oz. to $100 \mathrm{ft}$. of drill ....10 lbs. Beet, mangel, $1 \mathrm{oz}$. to $100 \mathrm{ft}$. of drill..... 5 lbs.

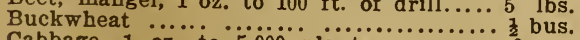
Cabbage, 1 oz. to 5,000 plants $\ldots \ldots \ldots \ldots \ldots .2$ oz. Carrot, $1 \mathrm{oz}$. to $100 \mathrm{ft}$. of drill $\ldots \ldots \ldots \ldots \ldots 2 \mathrm{l}$ lbs. Cauliflower, 1 oz. to 5,000 plants $\ldots \ldots \ldots 2 \frac{2}{2}$ ozs. Celery, 1 oz. to 15,000 plants $\ldots \ldots \ldots \ldots .2$ ozs. Clover, Alsike and White Dutch .........6 lbs. Clover, Lucerne, Large Red and Crimson 8 lbs. Clover, medium ......................... 8 lbs. Corn, Sweet, $\frac{1}{3}$ pint to 100 hills $\ldots \ldots \ldots \ldots . . . \ldots$ pts. Corn, North Dakota Flint, about $\ldots \ldots \ldots . \cdots 35$ lbs. Cucumber, 1 oz. to 100 hills ................ I lbs.

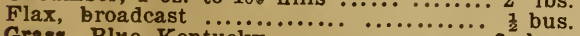
Grass, Blue Kentucky $\ldots \ldots \ldots \ldots \ldots \ldots \ldots . \ldots \ldots \ldots$

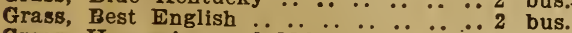

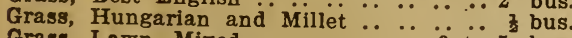
Grass, Lawn, Mixed .......... Grass, Orchard, Perennial Rye, Red Top,

Fowl Meadow and Wood Meadow ...2 2 bus.

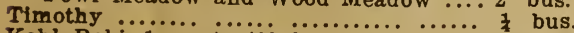

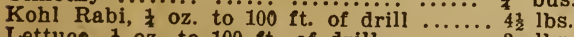
Lettuce, $\frac{1}{2}$ oz. to $100 \mathrm{ft}$. of drill .......... Melon, Musk, 1 oz. to 100 hills ............... 1 lb. Melon, Water, $4 \mathrm{oz}$. to 100 hills $\ldots \ldots \ldots \ldots .2$ lbs. Nasturtium, 2 oz. to $100 \mathrm{ft}$. of driil .......... Onion Seed, $\frac{1}{2}$. to $100 \mathrm{ft}$. of drill $\ldots 4$ to 5 lbs.

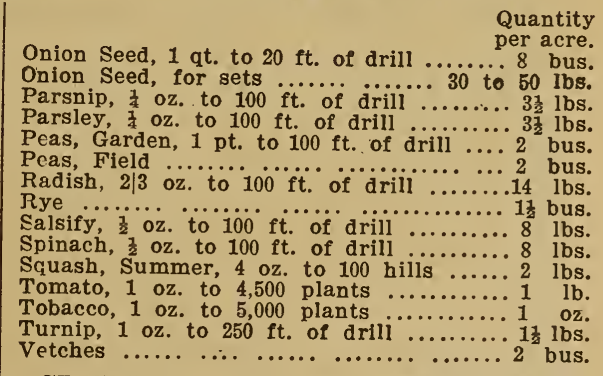

CLUBS.-We offer the following liberal indicements to Clubs, or those wishing to purchase seeds in packets. The seeds will be sent by mail, post-paid, but these low rates apply to seeds in packets only, and at Catalogue prices, but on anything over 1 lb. no reduction whatever will be allowed from Catalogue price.

Send us-

$\$ 1.00$ and select packets to the value of... \$1.15

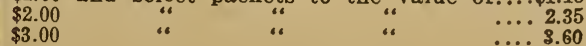

$\$ 4.00 \quad$ " $\quad$ ". $\quad \ldots .8 .85$ 


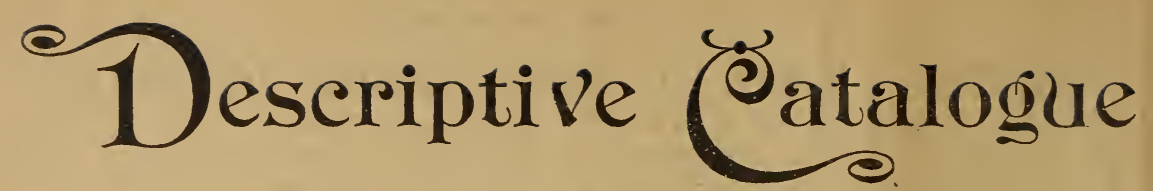

With General Directions for Cultivation.

\section{Artichoke.}

Large Globe.-The best sort for general use. Buds large, nearly round; scales deep green, shading to purple, very thick and fleshy. Pkt. 5c.; oz., 40c.

\section{Jerusalem Artichoke Roots.}

The Large New Variety.-Produces from 400 to 800 bushels per acre. An excellent food for cattle, sheep, horses and pigs. Per lb., 10c.; 3 lbs., by mail post paid, $35 \mathrm{c}$.

\section{Asparagus.}

A most valuable vegetable, and one of the first to come to our table in the spring. There is no vegetable which can be produced for a term of years so cheaply as this. Every garden should have a bed of it.

Palmetto (new).--Said to be much earlier, yielding better, more even and regular in its growth than any other variety. Pkt., 5c.; oz., 10c.

Conover's Colossal.-A large variety, which in the richest soil will produce immense shoots of fine quality. Pkt., 5c.; oz., 10c.; 2 ozs., $15 \mathrm{c}$.

\section{Beans: Dwarf, Snap, Bush.}

Yosemite IMammoth Wax.-The pods frecquently attain a length of ten to fourteen inches, with the thickness of a man's finger, and are nearly all solid pulp, the seeds being very small when the pods are fit for use. The pods are a rich golden color, and are absolutely stringless, cooking tender and delicious. This is the coming Wax Bean for family or market purpcses. It is enormously productive, as many as 50 of its monster pods having bcen counted on one bush. Pkt., 5c.; per 1b., 20c.; by mail, $25 \mathrm{c}$.

Golden Wax.-One of the earliest Wax Beans. Pods large, brittle, entirely stringless and of a beautiful golden wax color; excellent for string beans, shells easily and is good dry. Pkt., 5c.; 1b., 20c.; by mail, 25c.

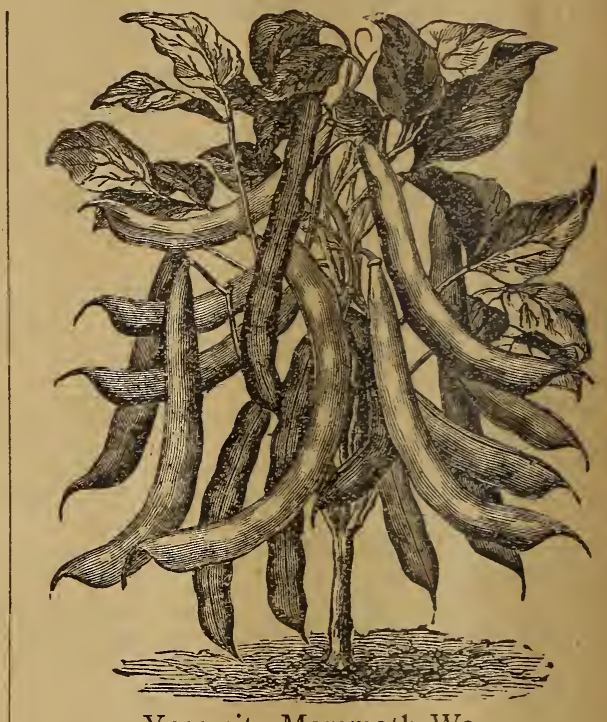

Yosemite Mammoth Wax.

Winnipeg Early Giant Wax or Butter.-This is really one of the most valuable varieties for either private or market garden purposes. It is earlier than either the Black or Golden Wax Sorts, and has a peculiar value in the fact that it is always exempt from rust. The pods are of very large size often from 6 to 9 inches long; exceedingly succulent and tender, when full grown. It is an enormously productive variety. Per pkt., 5c.; lb., 30c.; by mail, 35c.

Prolific German Wax, Black Seed.An improved strain of Black Wax, having longer, whiter and more fleshy pods, and being much more productive. Market gardeners, who raise Black. Wax, cannot afford to use any other strain. Pkt., 5c.; 1b., 20c.; by mail, 25c.

German Wax, White Seeded. - Pods broader and whiter than the last, vine more delicate, seeds white. Pkt., 5c.; lb., 20c.; by mail, 25c.

Early China, Red Eye--Very early. Pods green, long, flat, but of good quality. Pkt., 5c.; 1b., 20c.; by mail, $25 \mathrm{c}$. 
Butter Beans.-Exceedingly rich and tender, fine for family use. Pkt., $5 \mathrm{c}$.; lb., $20 \mathrm{c}$; by mail, $25 \mathrm{c}$.

Early Long Yellow, Six Weeks.(Kidney shaped) - Very profitable for either field or garden culture. Pkt., 5c.; 1b., 20c.; by mail, 25c.

Broad Windsor.-Large, one of the best, and ripens well in our climate; very prolific. Pkt., 5c.; 1b., 20c.; by mail, 25 c.

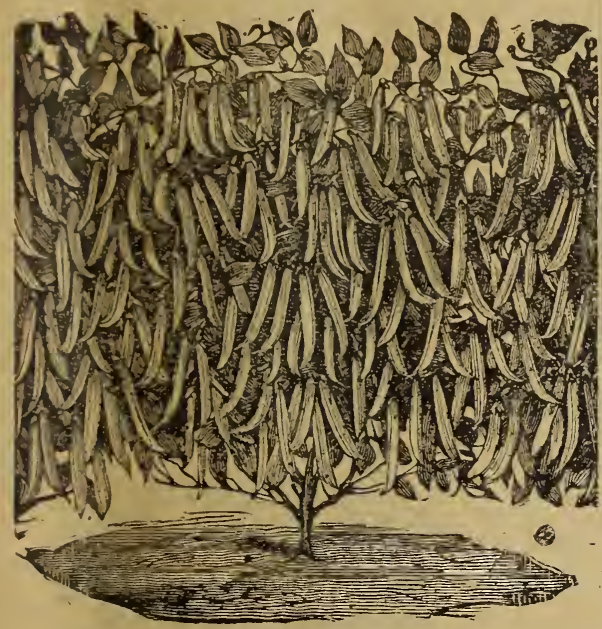

Golden Wax Bean.

Extra Early English Kidney Bean, direct from England.-A favorite with all on account of its adaptability to any soil, and therefore a large yielder. Good for family use, as it keeps in bearing longer that any other bean. Very beautiful and tender. Pkt., 5c.; $\frac{1}{4}$ lb., 15c.; 1 lb., 40c.

\section{Beans: Pole or Running.}

Yard Long, or Cuban Asparagus Bean.-This is quite a curiosity. It is a Pole Bean, with dark green foliage, and pods growing two feet and upward in lerigth. The pods, of such extraordinary le1:sth, are produced abundantly. Very crisp, tender and sweet. Pkt., $5 \mathrm{c}$.; $\frac{1}{4} \mathrm{lb}$., $15 \mathrm{c.;} 1 \mathrm{lb}$., 50c.; by mail, $55 \mathrm{c}$.

Lazy Wife's.-We don't know how it got such a name, but it's a good one for the bean, as its great productiveness enables one to pick a mess in a remarkably short time. This, of course, is a great advantage to all, and particularly to one whe is inclined to take it easy. The pods are flattish, oval-shaped and of an exceedingly rich, buttery flavor. It is certainly a splendid bean, even though it has a peculiar name. Pkt., 5 c.; $\frac{1}{4} \mathrm{lb} ., 20 \mathrm{c}$.; by mail, $25 \mathrm{c}$.
White Runner. Culitvated chiefly for its beauty. Vines and leaves large, blossoms large, pur e white. Pkt., 5c.; 1b., 20c.; by mail, $25 \mathrm{c}$.

Scarlet Runner.Similar to the last, but with scarlet blossoms. Beans lilac purple. Pkt., 5c.; lb., $30 \mathrm{c}$; by mail, $35 \mathrm{c}$.

\section{Beets.}

Extra Early Egyptian Blood Turnip.-The earliest and best for forcing. V e r y crisp and tender. Pkt., 5c.; oz., 10c.; 2 oz., 15c.; 1 1b., 25c.; lb., 80c.; by mail, $85 \mathrm{c}$.

Improved Long Dark Blood. - The best variety for winter use. Very dark red and of excellent flavor. Pkt. 5c.; oz., 10c.; 2 oz., 15c.; $\frac{13}{4} 1 \mathrm{~b}$, 25c.; 1b., 80c.; by mail, 85c.

Early Eclipse.An improved extra early sort. Very desirable for bunching. Pkt., 5c.; oz., 10c.; 2 oz., $15 \mathrm{c}$.; $11 \mathrm{l}$ lb., $25 \mathrm{c}$; lb., 80 c.; by mail, $85 \mathrm{c}$.

Improved Early B l o o d Turnip. Formed by careful selection from the above. Darker and better formed. Pkt., 5c.; oz., 10c.; 2 oz., 15c.; $\frac{1}{4}$ 1b., 25c.; 1b., 90c.: by mail, $95 \mathrm{c}$.

Half Long Deep Dark Blood Red.The best for family use, te nder and sweet, not requiring to be cut in two for boiling. Pkt., 5c.; oz., 10c.; 2 oz., 15c.; $\frac{1}{4}$ ib., 25c.; 1b., 80c.; by mail, $85 \mathrm{c}$.

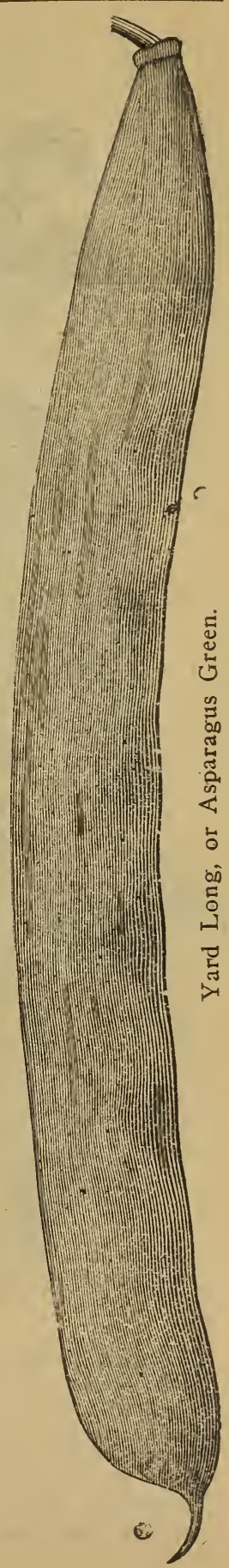


French White Sugar, Red Top.-Cultivated largely for stock feeding and making sugar; excellent. Pkt., 5c.; $\frac{1}{4} \mathrm{lb}$., 10c.; lb., 30c.; by mail, 35c.

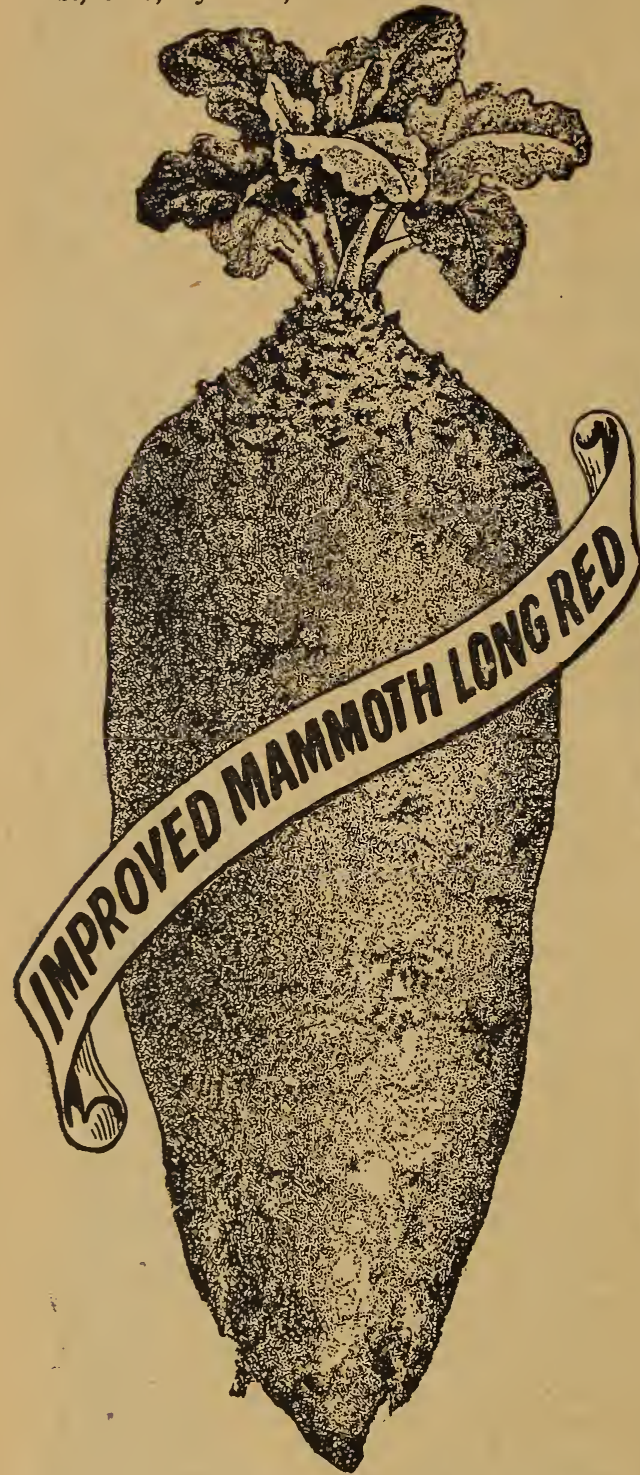

Improved Mammoth Long Red Mangel Wurtzel.-An improvement on the old varieties, giving the largest weight of any variety, and also of deeper color and better quality. Pkt., 5c.; $\frac{1}{4}$ lb., 10c.; lb., 30c.; by mail, 35c.

Carter's Warden Prize Yellow Globe Mangel Wurtzel.-A Yellow Globe vari- ety, with small top, keeps well. Pkt., 5c.; 1 lb., 10c.; 1b., 30c.; by mail, 35c.

Red Globe Mangel Wurtzel.-Similar to Yellow Globe, and equally desirable for shallow soils. Pkt., 5c.; $\frac{1}{4}$ lb., 10c.; lb., 3ic.; by mail, 35c.

Golden Tankard Mangel Wurtzel.Tankard shaped top and neck small, flesh yellow; a great improvement. Pkt., 5c.; lb., 10c.; lb., 30c.; by mail, 35c.

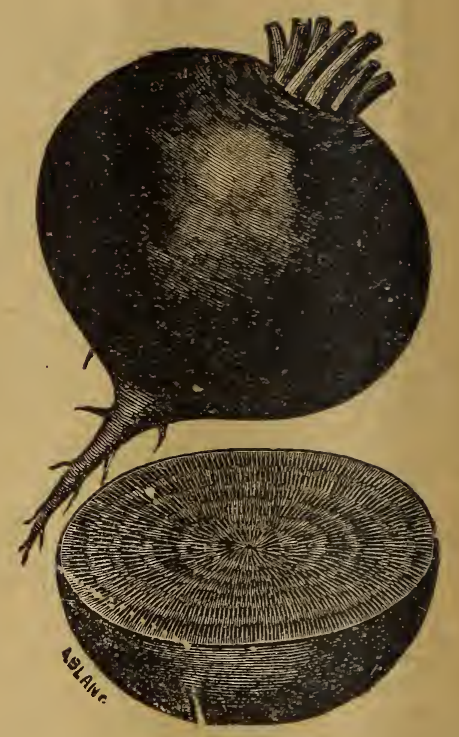

Beet-Improved Early Round Turnip.

\section{Brussels Sprouts.}

Best Imported.-There are few, if any distinct varieties, and this is the best stock procurable. Pkt., 5c.; oz., 20c.; 2 oz., 35 c.; $\frac{1}{4}$ lb., 60c.

Write for prices for anything you may require not mentioned in this catalogue.

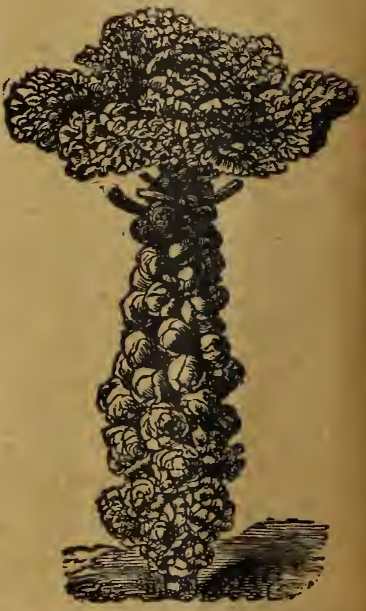

Brussels Sprouts. 


\section{Cabbage.}

Early Jersey Wakefield.-(True Jersey Variety).-The most popular early variety with northern market gardeners. It is hardy and produces large, solid, conical heads, with few outside leaves. Pkt., 5c.; oz., 20c.; 2 oz., 35c.; $\frac{1}{4}$ lb., 60 c.

Early York.-An old and very popular sort. Stem short, head oval, small, plant compact. Pkt., 5c.; oz., 10c.; 2 oz., 20c.; 卉 1b., 35c.

Early Winnigstadt.-Certain to head. Heads medium size, pointed, of good flavor, and keeps well. Decidedly the best sort for those not familiar with the proper methods of culture. Pkt., 5c.; oz., 20c.; $\frac{1}{4}$ lb., 50 c.

Early Drumbead.-Similar to the Late Drumhead, but earlier. Pkt., 5c.; oz., 20c.; 2 oz., 35c.; 1 lb., 40 c.

Henderson's Early Summer. - The ea!liest large heading variety. Growth compact, heads large, flat, handsome, keeps well after maturing. Stands shipping well. Pkt. 5c.; oz., 20c.; 2 oz., 35c.; $\frac{1}{4}$ lb., 60c.

Succession.-(Henderson's True Stock) -A medium early variety, and such a grand keeper that it is valuable for both early and late use. The largest growers say it is one of the best marketing cabbages ever introduced, and we want to adil that it is also fine for the home garden. Pkt., 5c.; oz., 25c.

Stone Mason Marblehead.-Of very fine flavor, sweet and crisp. Very hardy, and will withstand frosts that would kill

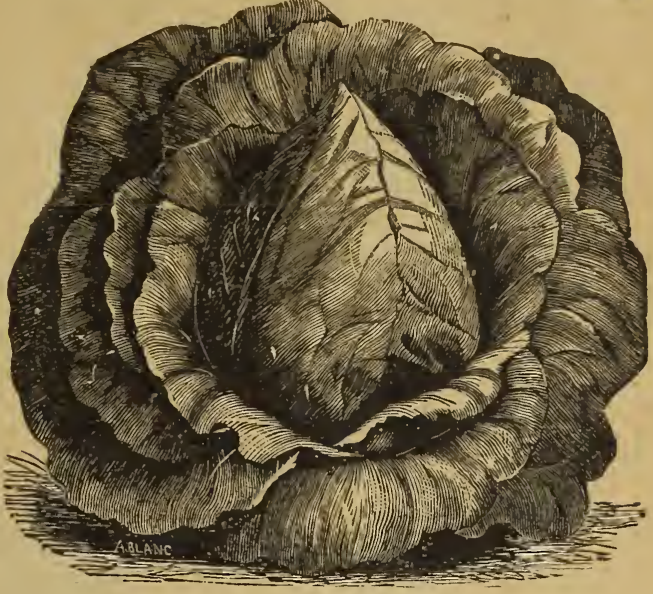

Early Jersey Wakefield,

other varieties. Pkt., 5c.; oz., 20c. ; 2 ozs., 35c.; $\frac{1}{4}$ lb., 50c.

Henderson's Autumn King.-Is the si'perior of all other winter cabbage and the best keeper. It produces enormous solid heads of that glaucous green shade that is most desirable in a cabbage. It has also such small outer leaves that it can be planted much closer together than the ordinary later sorts, and it can be relied upon to produce a greater weight of crop per acre than any other variety from the fact that it produces very few outer leaves and goes all to head. Without doubt the best late cabbage yet introduced. Pkt., 5़c.; oz., 20c.; 2 ozs., 35c.; $\frac{1}{4}$ lb., 50c.

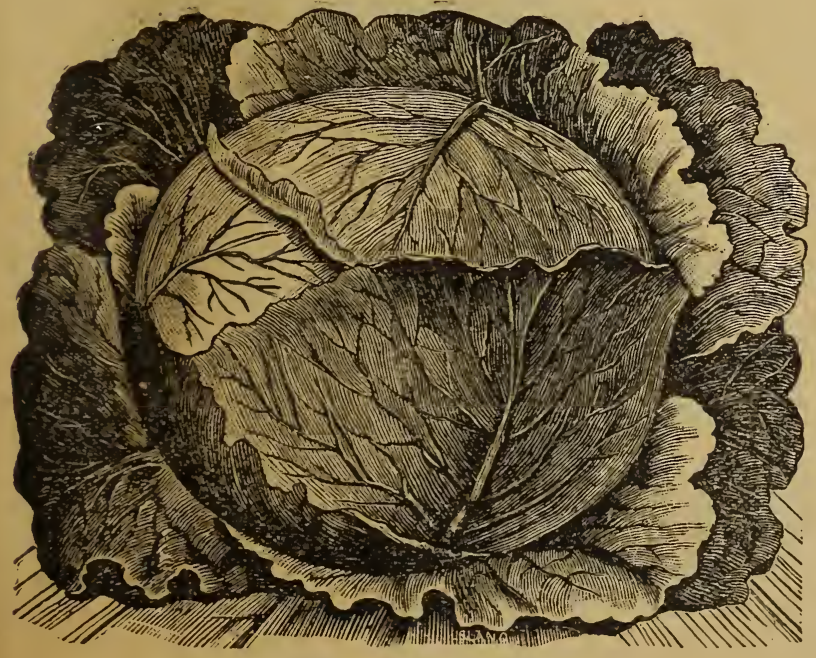

Premium Drumhead.
Premium Flat Dutch.The best variety for winter use. It is very sure to head, and is of the best quality. Pkt., 5c.; oz., $20 \mathrm{c}$; 2 oz., 35c.; $\frac{1}{4}$ lb., $50 \mathrm{c}$.

Premium Drumhead.A large variety, carefully selected for years. It is sure to head, and is the best sort for fall shipment. Pkt., 5c.; oz., 20 c.; 2 oz., 35 c.; $\frac{1}{4}$ lb., $50 \mathrm{c}$.

Fottler's Early Drumhead, or Bru ns w i k Short Stem.-An improved stock of the last, with very large heads borne on exceedingly short stems. Pkt., 5c.; oz., 20c.; 2 oz., $35 \mathrm{c}$; $\frac{1}{4}$ lb., $50 \mathrm{c}$. 
Darish Ballhead Cabbage.-This distinct variety has become very popular, both on account of its uniformity in heading and from the character of the heads, which are extremely hard and solid, and for a cabbage of this type has been greatly increased the past few seascins by the importation of large quantities from abroad during the winter and early spring months to our large markets; the fine condition in which they arrive being a strong indorsement of their excel- lent keeping qualities. For planting late in the spring for a fall crop for winter use this variety has few equals, as it seems able to withstand drought and succeeds in pcor soil better than most of our American sorts. Heads round in form, eight to ten inches in diameter and very solid; few outer leaves, and these folded closely about the heads. The heads keep excellently through the winter when buried, coning out quite solid in the spring. Pkt., 5 c.; oz., $25 \mathrm{c}$.; 2 oz., $45 \mathrm{c}$.; $\frac{1}{4}$ 1b., $75 \mathrm{c}$.

\section{Red Cabbage.}

Mammoth Red Rock.-By far the largest, best and sweetest heading red cabbage in cultivation. Pkt., 5c.; oz., 20c.

Red Dutch.-Pk., 5c.; oz., 20c.; 2 oz., 35c.

Large Red Drumhead.Of a fine, deep purplish red and much esteemed for pickling or for cold slaw. Pkt., 5c.; oz., 20c.; 2 oz., 35c.; $\frac{11}{4} 1 \mathrm{~b}$. , $60 \mathrm{c}$.

Savoy, Improved American.--Much more solid and compact than the Green Globe, but not so finely curled. Pkt., 5c.; oz., 15c.; 2 oz., $25 \mathrm{c}$; $\frac{1}{4} \mathrm{lb} ., 40 \mathrm{c}$.

\section{Carrots.}

The earrot deserves to be more extensively cultivated, as it is very nutritious, and one of the best and cheapest foods for stock.

English or French Horn. - This is the earliest carrot in cultivation, fine grained and agreeably flavored. Pkt., 5c.; oz., 10c.; 2 oz., 20c.; $\frac{1}{4}$ lb., 30c.; 1 lb., $\$ 1.00$; by mail $\$ 1.05$.

Guerande, or $\mathrm{Ox}$ Heart.-A broad, top shaped carrot, easily dug. Flesh fine grained and sweet. Pkt., 5c.; oz., 10c.; 2 oz., 15c.; $\frac{1}{4} 1$ lb., 25 c.; 1b., $90 \mathrm{c}$; by mail, $95 \mathrm{c}$.

Early Scarlet, Stump Rooted.-Of medi-early variety; color deep orange, fine grained and agreeably flavored. Pkt., 5c.; oz., 10c.; 2 oz., 15c.; $\frac{1}{4}$ lb., 30c.; lb., $\$ 1.00$; by mail, $\$ 1.05$.

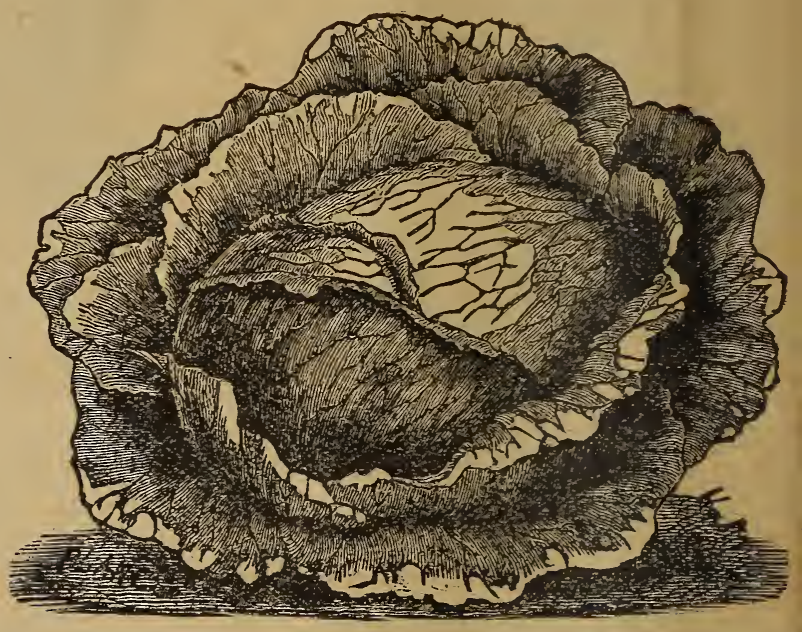

Fottler's Early Drumhead.

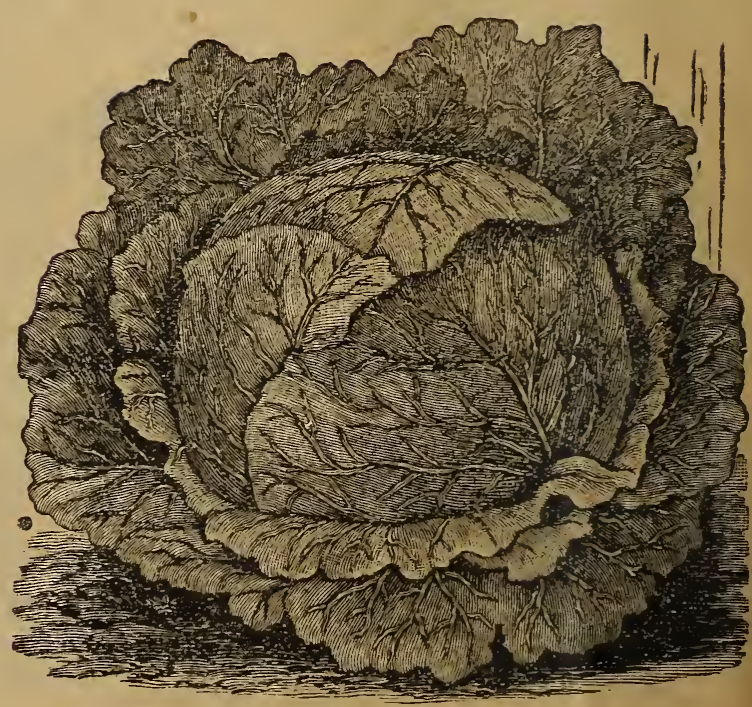

Henderson's Autumn King. 


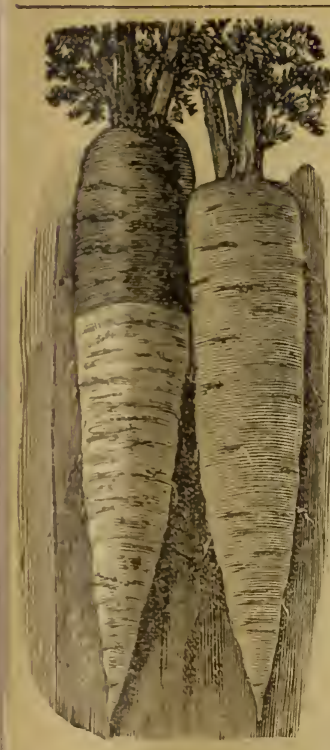

\section{Carrots-continued.}

Half Long Scarlet Nantes.Similar to the last, but deeper color. Very fine quality. Pkt., 5c.; oz., 10c.; 2 oz., 15c.; $\frac{1}{4}$ lb., 30c.; 1b., $\$ 1.00$; by mail, $\$ 1.05$.

Chantenay.-A sort uniformly half long, smooth and deep, rich color. Medium early, with small tops. Pkt., 5c.; oz., 10c.; 2 oz., 15c.; $\frac{1}{4}$ lb., 25c.; lb., 80c.; by mail, $85 \mathrm{c}$.

Danvers, Orange.-A new sort. Yields twenty to thirty tons per acre. Medium length; very handsome and easily dug. Pkt., 5c.; oz., 10 c.; 2 oz., 15c.; $\frac{1}{4}$ lb., 30c.; 1b., $\$ 1$; by mail, $\$ 1.05$.

Long Orange.-The standard sort - suitable for the table and main field crop. Plt., 5c.; oz., 10c.; 2 oz., 15c.; $\frac{1}{4}$ lb., 20c.; 1b., 70c.; by mail, $75 \mathrm{c}$.

Scarlet Intermediate.-Medium size; smooth in skin and rich in color. Very fine flavor. Pkt., $5 \mathrm{c}$.; oz., Large White and Long 10c.; 2 oz., 15c.; $\frac{7}{4}$ lb., 25c.; 1b., \$1; Yellow Belgian. by mail, $\$ 1.05$.

Improved Short White. - Owing to its enormous productiveness and its growing well out of the ground, making it comparatively easy to harvest. Roots shcrt, very heavy at shoulder, regularly tapering to a point, of uniform color; ight green above ground, white below, fesh rich white, solid and crisp, and of the inest flavor. Pkt., 5c.; oz., 10c.; $\frac{1}{2}$ lb., Lǒc.; 1b., 70c.; by mail, 75c.

Yellow Belgian-Similar to White Belyiar: in every respect except color. Pkt., ic. : oz., 10c.; 11 b., $15 \mathrm{c} ; 1 \mathrm{~b} .60 \mathrm{c}$; by mail, $65 \mathrm{c}$.

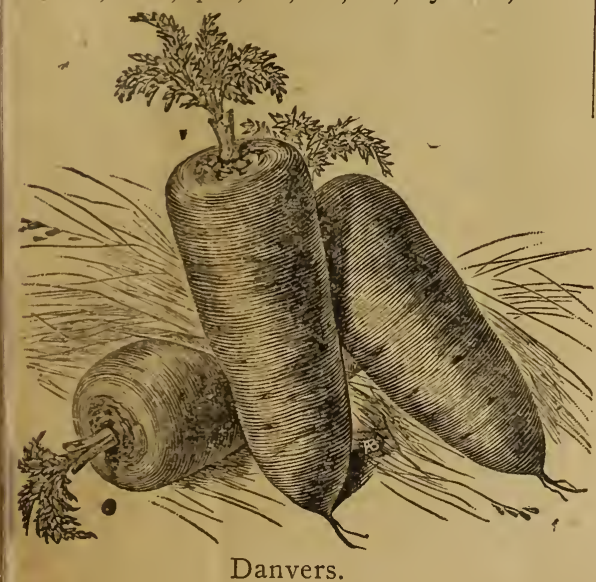
60 c.; by mail, 65 c.

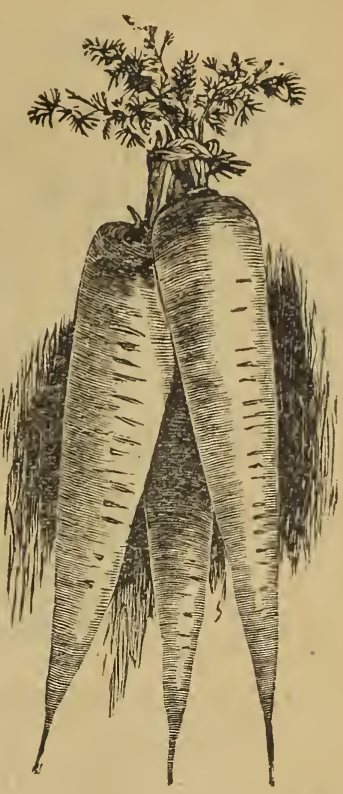

Improved Long Orange.

Large White Vosges. - Roots very large, similar in shape, although more pcinted, than the Guerande. Skin and flesh white, and the latter is of much better quality than that of the other white varieties, so that it is often used for the table. Easily dug, and a very distinct valuable variety. Pkt., 5c.; oz., 10c.; $\frac{1}{4} \mathrm{lb}$. , 15c.: lb., 60c.; by mail, 65c.

Long White Belgian.-Grows onethird out of the ground. Root pure white, grcen above ground, with small top. Flesh rather coarse, but the roots on light rich ground grow to a large size, and are extensively grown for stock feeding. Pkt., 5c.; oz., 10c.; $\frac{1}{4}$ lb., 15c.; lb.,

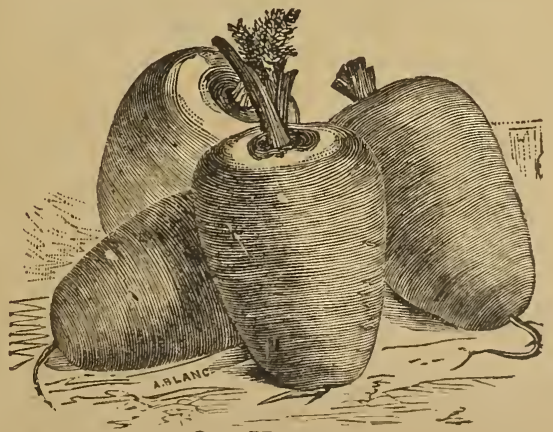

Ox Heart. 


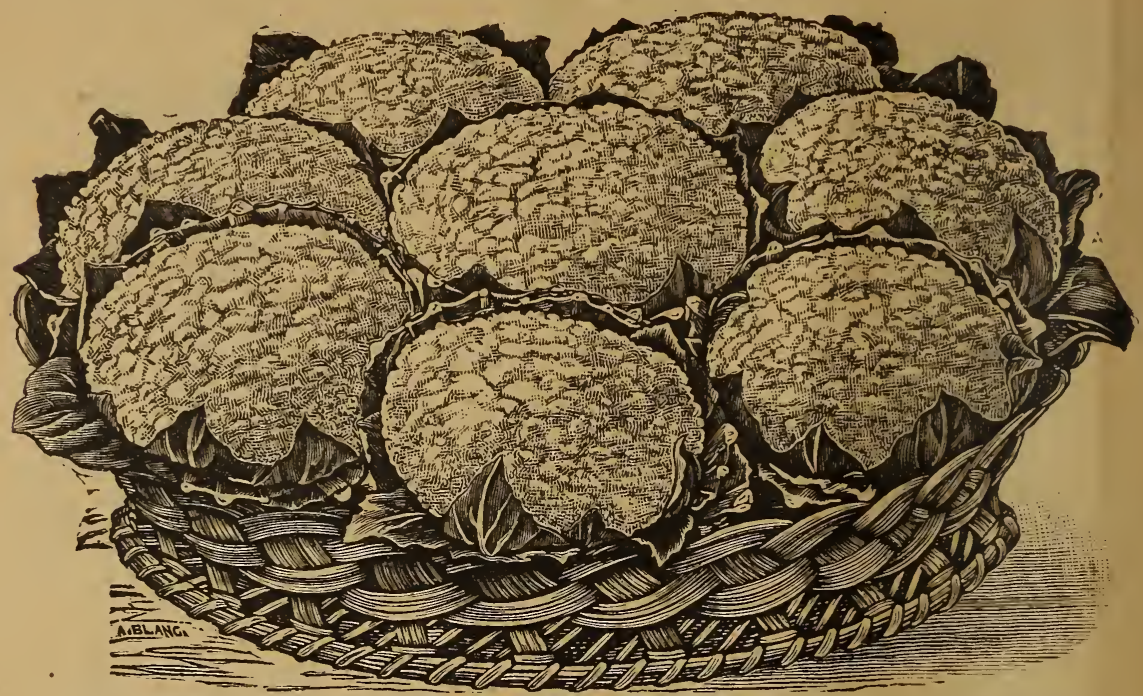

\section{HENDERSON'S EARLY SNOWBALL CAULIFLOWER.}

The Earliest.

The Surest Header. The Best Variety for either Market or Family Gardens.

Whether intended for private use or to be grown for market, Henderson's Early Snowball Cauliflower is superior to all others. FIRST, because it is the earliest of all Cauliflowers, as has been conclusively shown season after season, since we first made its merits known; SECOND, because, under the conditions of an ordinarily favorable season, nearly every plant will form a perfect snowwhite head, averaging nine inches in diameter; THIRD, for the reason that its close-growing, compact habit enables $1 / 3$ more to be planted or the same space of ground than can be done with any other variety. It also does equally well for late planting. Pkt., 25c.; $\frac{1}{4}$ oz., $\$ 1.10 ; \frac{1}{2}$ oz., \$2.15; oz., \$4.

Early Snowball.-Early and reliable. Its hardiness, sure heading and compact growth make it one of the best for forcing or wintering over. Pkt., 25c.; $\frac{1}{2}$ oz., $\$ 1.50 ;$ oz., $\$ 2.75$.

Early Dwarf Erfurt.-An extra early dwarf, compact variety. Much prized for early market use. Pkt., 20c.; $\frac{1}{2}$ oz., $\$ 1.00$; oz., $\$ 2.00$.

Early Paris.-Similar to the preceding, though not quite so early. Excellent for home garden. Pkt., 10c.; $\frac{1}{2}$ oz., 75c.; oz., $\$ 1.30$.

Early London.-A standard variety, very tender and quite early, heads compact, solid and of delicious flavor, plant and leaves of medium size. Good for general use. Pkt., 10c.; $\frac{1}{2}$ Oz., 60c.; oz., \$1.

Large Algiers.-A popular late sort, sure to head, and of best quality. Pkt., 10c.; $\frac{1}{2}$ oz., 60c.; oz.; $\$ 1.00 ; 2$ oz., $\$ 1.75$.

Veitch's Autumn Giant.-A distinct and valuable late variety. The heads are very large, beautifully white, firm and compact, and remain a long time fit for use. Pkt., 10c.; $\frac{1}{2}$ oz., 35 c.; oz., 60 c.; 2 oz., $\$ 1.00$.

La Normands.-Short stem. Pkt., 10c.; $\frac{7}{2}$ oz., 60 c.; oz., $\$ 1.00 ; 2$ oz., $\$ 1.75$.

Culture.-Cultivate as directed for early cabbage, but care should be taken to plant the seed and set out the plants so that they will head during cool, moist weather. The best of plants from finest stock will fail to head if the weather is hot and dry. If possible, arrange the planting so that they can be watered, as an abundance of water is essential to success.

NOTE.-Any person receiving this Catalogue and not requiring any seeds, kindly hand it to your neighbor that you think will require same, or any person of your acquaintance who would like one, by sending their name and address, can have one FREE OF CHARGE. 


\section{Corn.}

Large White-Cob Cory.-This new strain is the earliest, while the ears are of larger size, with the grains placed more compactly. The cobs being white, the grains are entirely free from the dark tinge noticeable in the original strain when the ears are allowed to remain too long on the stalk. The ears of the new Large WhiteCob, or "Mammoth Cory," retain the pearly whiteness of the grains when cooked. Pkt., 5c.; 1b., 15c.; by mail, 20c.

Early Minnesota. - The standard early scrts. Ears small, long, pointed. Kernels las e for so early a variety. Much liked b) market gardeners. Pkt., 5c.; lb., 15c.; b: mail, 20c.

jarly Sweet or Sugar.-Ears of good size, tender and sugary. An excellent table sort. Pkt., 5c.; 1b., 15c.; by mail, 20 c. $15 \mathrm{c}$.

Pop Corn.-Pkt., 5c.; 1b., 10c.; by mail,

\section{Chicory.}

Large Rooted or Coffee.-Used as a substitute for coffee. Cultivated same as carzot. Pkt., 5c.; oz., 10c.; 2 oz., 15c.; $\frac{1}{4}$ 1b., $25 \mathrm{c}$; ; 1b., $60 \mathrm{c}$.

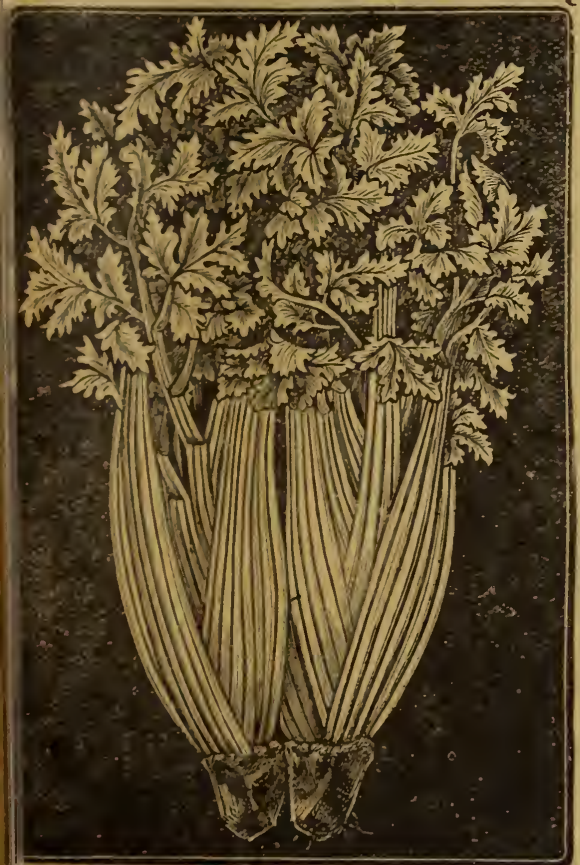

White Plume.

\section{Cress, or Pepper Grass.}

Curled.-Very fine for salad; will bear cutting several times. Pkt., 5c.; oz., 10c.

Water Cress.-This is an entirely different variety from the above, and thrives best in shallow water on the edge of streams, where it increases both by spreading of the roots and by seeding. It has a pleasant, pungent taste; agreeable to most people. Pkt., 5c.; oz., 40 c.

\section{Celery.}

Henderson's New Pink Plume.-Is a strung, healthy, compact grower, with no tendency to rust; stems very solid and crisp, extra early and a long keeper. It is a self-blanching variety in the same sense as White Plume-that is, it requires but a slight earthing up or banking to prepare this variety for the table. Pkt., 5c.; oz., 25.

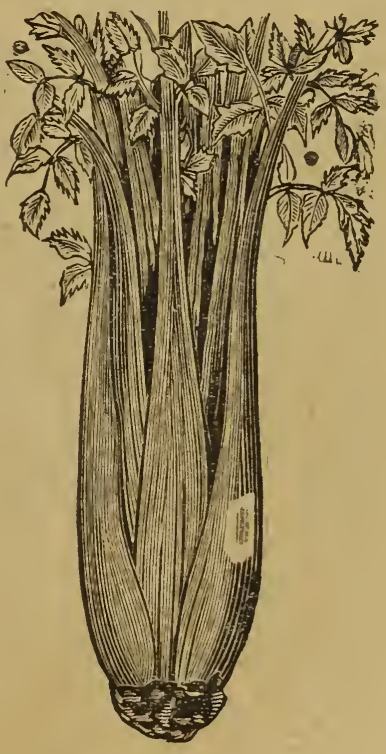

English White Solid.

Golden Self-Blanching.-A most valuable variety, partaking of the character of the celebrated White Plume, inasmuch as it simply needs a slight earthing up or "handling." It is of a beautiful waxy golden color, very solid, and of a rich nutty flavor. Pkt., 5c.; oz., 40c.; 2 oz., 75c.

English White Solid.-Dwarf compact plant, with large, white solid stalks. One of the best for storing for winter use. Pkt. 5c.; oz., 20c.; 2 oz., 35c.; + lb., 60c. 


\section{Celery.}

White Plume.-The inner leaves are white, and the blanched celery is handscme and attractive. It comes to maturity earlier than most sorts. Pkt., 5c.; oz., 30 c.; 2 oz., 55 c.; $\frac{1}{4}$ lb., $\$ 1$.

Giant Pascal.-This is a green leaved variety developed from the Golden Yellow Large Solid, and has no superior for fall and winter use. It blanches very quickly after earthing up, when it is of a beautiful yellowish white color, very solid and crisp and of a nutty flavor, which cannot be equalled by any other sort. Pkt., 5c.; oz., 20c.; 2 oz., 35c.

Celery for Flavoring.-Pkt., 5c.; $1 \mathrm{oz}$, 15c.; $\frac{1}{4}$ lb., $40 \mathrm{c}$; by mail, $45 \mathrm{c}$.

Celeriac, or Turnip Rooted.-The root of this variety is turnip shaped and is extensively grown for flavoring soups. Pkt., 5c.; oz., 20c.; 2 oz., 35c. $15 c$.

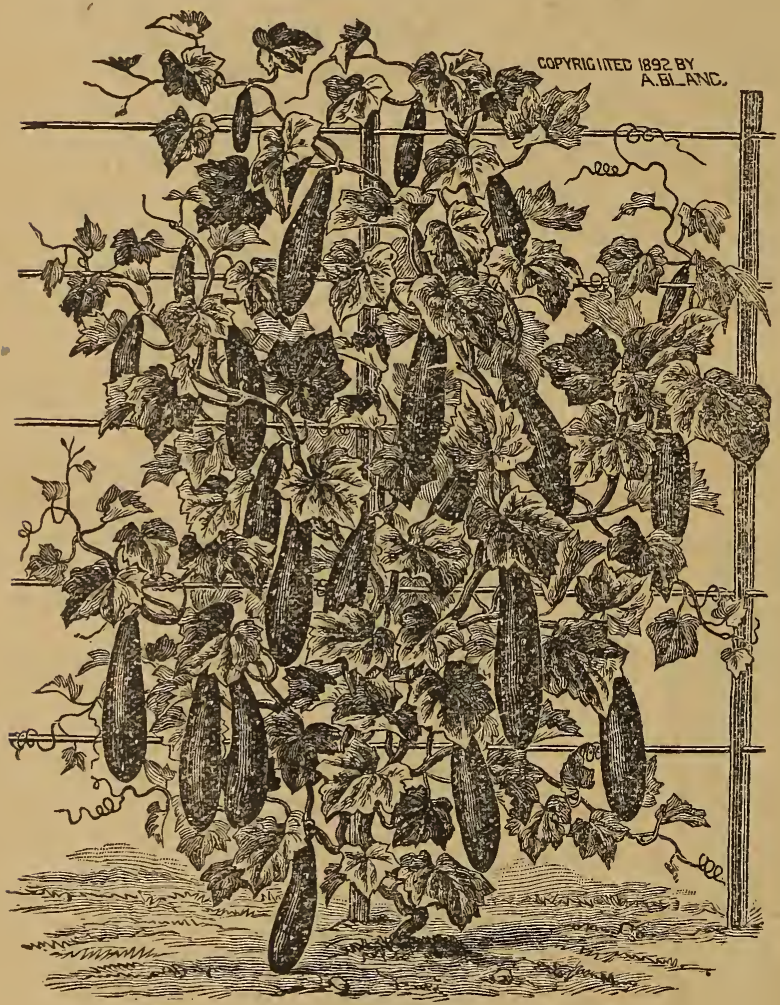

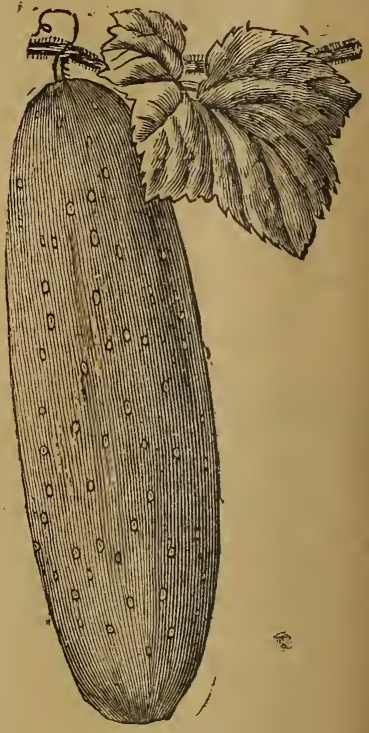

Early White Spine.

Japanese Climbing Cucumber.

\section{Cucumber.}

Japanese Climbing.-It is entirely distinct, being much more rugged in its constitution and less susceptible to disease than the ordinary cucumbers, and is immensely more prolific, each vine producing from 25 to 30 splendid cucumbers, even on poor soil. The quality is splendid, and is pronounced by connoisseurs to be superior to the ordinary varieties. It is well adapted for pickling as well as slicing for salad. Pkt., 5c.; oz., 15c.
English Frame or Forcing Variety.Duke of Edinburgh. Pkt., 25c.

Early Russian.-One of the earliest varieties, producing its short, tender, crisp fruit in pairs. Pkt., 5c.; oz., 10c.; 2 oz., 15c.; $\frac{1}{4} 1 \mathrm{~b} ., 25 \mathrm{c}$.

Early Cluster.-Vine healthy and a strong grower. Fruit tender, seedy, good for the table. Pkt., 5c.; oz., 10c.; 2 oz., $15 \mathrm{c}$.; $\frac{1}{4}$ lb., $25 \mathrm{c}$. 


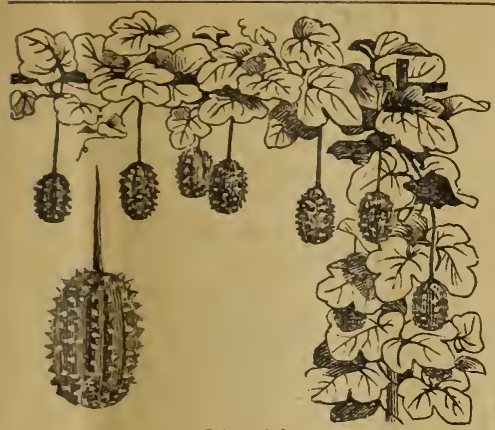

Gherkins.

\section{Cucumber.}

Gherkin. - A small, green, prickly cucumber for pickling. Should be pickled when very small. Pkt., 5c.; oz., 20c.; 2 oz., 3.5c. ; $\frac{1}{4}$ lb., $60 \mathrm{c}$.

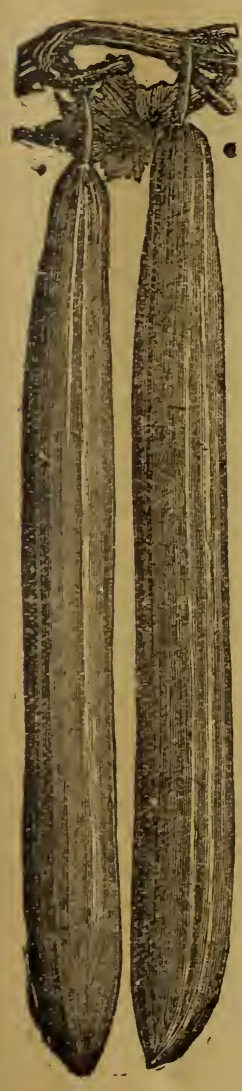

English Frame or Forcing Cucumber.
Rollison's Telegraph.-Very prolific, early crisp and of superior quality. Pkt., $25 \mathrm{c}$.

Improved Long Green.-An improved variety of Long Green, established by careful selection for many years. Fruit u1 iformly straight and handsome, and of the best quality. Pkt., 5c.; Oz., 10c.; 2 oz., $15 \mathrm{c}$; $\frac{1}{4} 1 \mathrm{~b} ., 25 \mathrm{c}$.

Early White Spine.-Intermediate in size and the earliest of the large varieties. Fruit very straight, smooth and handsome; greenish white and of the best quality. Pkt., 5c.; oz., 10c.; 2 oz., 15c.; $\frac{1}{4} 1 \mathrm{~b} ., 25 \mathrm{c}$.

Early Short Green.-Vine very hardy and productive. Fruit short, bright green, prickly, seedy, but tender, crisp and of a gcod flavor. Much liked by some growers for pickling, it retaining its color better than most sorts. Pkt., 5c.; oz., 10c.; 2 oz., 15c.; $\frac{1}{4} 1 \mathrm{~b} ., 25 \mathrm{c}$.

Jersey Pickling.-Forms a long, slender, cylindrical pickle, which is very crisp and tender. Pkt., 5c.; oz., 10c.; 2 oz., 15c.; $\frac{1}{4} 1 \mathrm{~b} ., 25 \mathrm{c}$.

\section{Egg Plant.}

Black Pekin.-Very early, prolific and of delicate flavor. Skin black and glossy. Weight eight to ten pounds. Pkt., 10c.; oz., $75 \mathrm{c}$.

\section{Kohl Rabi.}

Culture-Cultivate same as Ruta Baga for general, and like early cabbage for early crop. They should be used before they have attained their full growth.

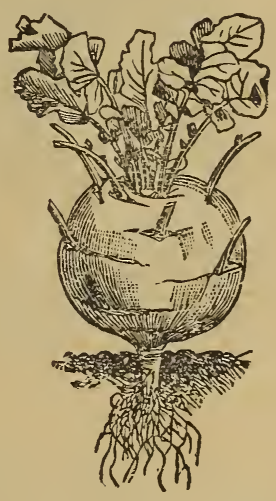

Vienna Kohl Rabi.

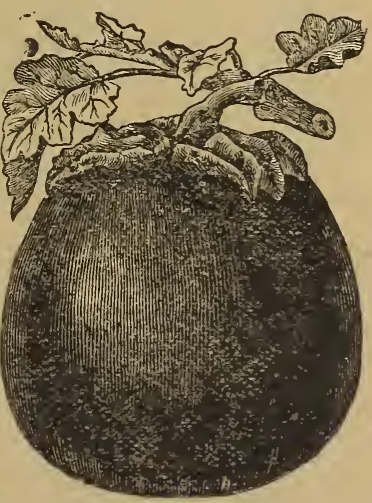

Black Pekin Egg Plant. 


\section{Kohl Rabi.}

Early White Vienna.-Very early, smiall, white bulb; best early variety for table. Pkt., 5c.; oz., 20c.; 2 oz., 35c.

Early Purple Vienna-Nearly identical with the last, except in color, which is a . bright purple. Pkt., 5c.; oz., 20c.; 2 oz., 35 c.; $\frac{1}{4} 1 \mathrm{~b} ., 60 \mathrm{c}$.

\section{Kale.}

Tall Green Curled Scotch.-The variety in most general use. Stands the winter without protection. Pkt., 5c.; oz., 15c.; 2 өz., 25c.; 索 1b., 40c.

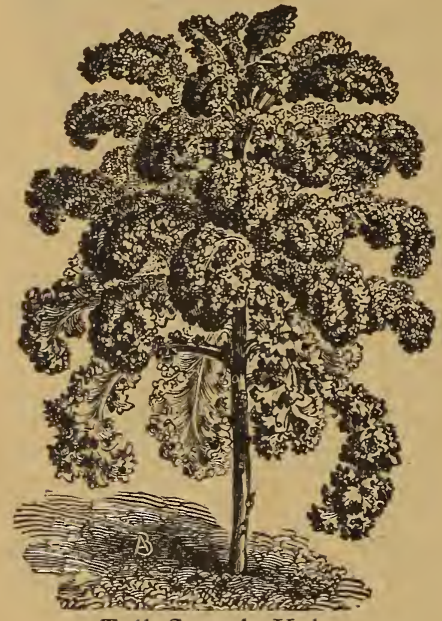

Tall Scotch Kale.

\section{Endive.}

Green Curled.-Has beautifully curled dark green leaves, which blanch white and are very crisp and tender. Pkt., 5c.; oz., $30 \mathrm{c}$.

\section{Leek.}

London Flag. - A large and strong plant with broad leaves, growing only on two sides, like the Flag. This variety is largely cultivated. Pkt., 5c.; oz., 15c.; 2 oz., $25 \mathrm{c}$.

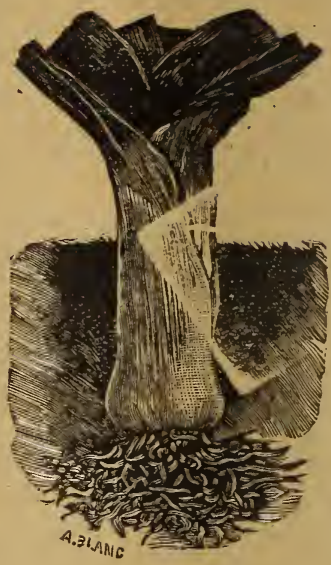

London Flag Leek.

\section{Lettuce.}

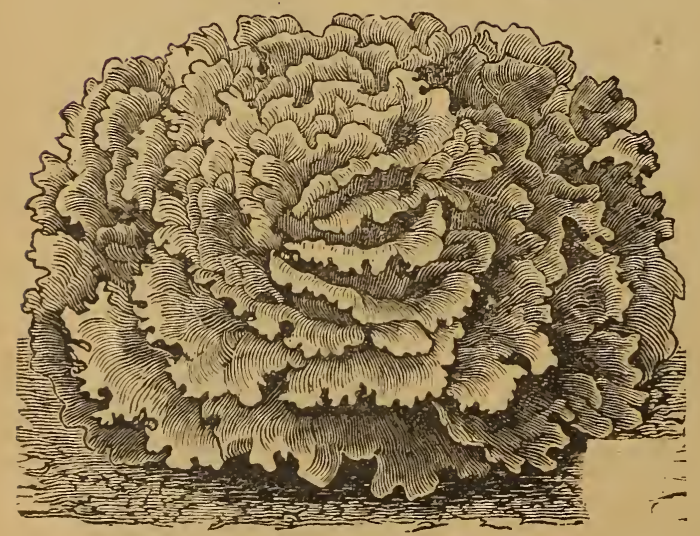

Prize Head.

Philadelphia Butter or Early Whitehead.-Medium sized, dark green, but white inside and very crisp. Pkt., 5c.; oz., 15c.; 2 oz., 25c; $\frac{1}{4}$ lb., 40c.

White Paris Cos.-Long, upright heads, with oblong leaves; tender, brittle and of mild flavor. Pkt., 5c.; oz., 20c.; 2 oz., 30c.; $\frac{1}{4}$ lb., 60c.

Brown Dutch.-(Seed Brown).An old sort, noted for its hardiness. Leaves large, thick, green, tinged with brown. It always forms a large solid head, which is somewhat coarse looking, but the inner leaves are beautifully blanched, exceedingly sweet, tender and well-flavored. Desirable because of its hardiness and fine quality. Pkt., 5c.; oz., 20c.; 2 oz., $35 \mathrm{c}$.

Large Drumhead or Victoria Cabbage.-Heads remarkab!y large and compact, crisp and tender. One of the finest summer varieties. Pkt., 5c.; oz., 15c.; 2 oz., $25 \mathrm{c}$; ; $\frac{1}{4} \mathrm{lb}$., $40 \mathrm{c}$. 


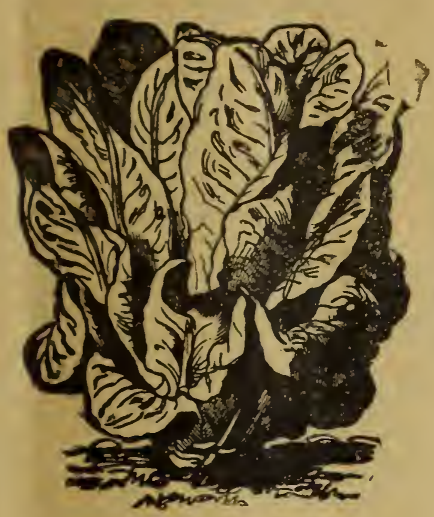

Lettuce-White Paris Cos.

\section{Lettuce.}

Grand Rapids.-Of handsome appearance, a strong grower, very crisp and tender, and not apt to rot, and will keep from wilting longer than any other. Per pkt., 5c.; oz., 20c.

Early Curled Silesia.-Early, makes a large, loose head, is of good flavor, tender and crisp. One of the best for bunching or cut lettuce. Pkt., 5c.; oz., 20c.; 2 oz., $30 \mathrm{c}$.; $\frac{1}{4} \mathrm{lb} ., 50 \mathrm{c}$.

Black Seeded Simpson.-Leaves very large, forming a compact mass. They are thin, very tender, and very light green. Popular among market gardeners. Pkt., 5c.; Oz., 20c.; 2 oz., 30c.; $\frac{1}{4} 1$ lb., 50c.

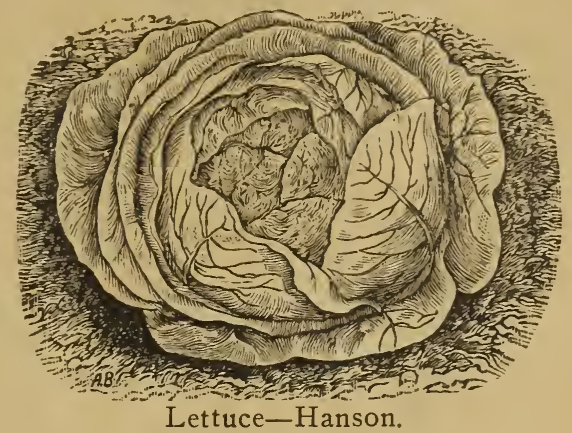

Simpson's Early Curled.-One of the be st early sorts for market use. Leaves crimped and tender. Pkt., 5c.; Oz., 15c.; 2 oz., 30c.; $\frac{1}{4}$ lb., 50c.

Early Prize Head. - The best lettuce known for family use. Forms a mammoth head, remains tender and crisp thrcughout the season, is prompt to head, b.tt slow to run to seed. Very hardy. Pkt., 5c.; oz., 15c.; 2 oz., 25c.; $\frac{1}{4} 1$ b., 40 c.

Hanson.-Heads of very large size, tender and crisp, has very few superiors for family use. Pkt., 5c.; oz., 15c.; 2 oz., 25c.; $\frac{1}{4}$ lb., $40 \mathrm{c}$.

Tom Thumb Lettuce.-Good for forcing, and most excellent for early spring sowing in the open garden. Of bright green appearance, each plant makes a solid, compact head, so hard and compact that it is well blanched within, rich and buttery. Per pkt., 5c.; oz., $15 \mathrm{c}$.

\section{Melon, Musk.}

Culture.-Cultivate as recommended for cucumbers, but avoid planting near those plants, as they will mix with and injure the quality of the melons. This or heavy

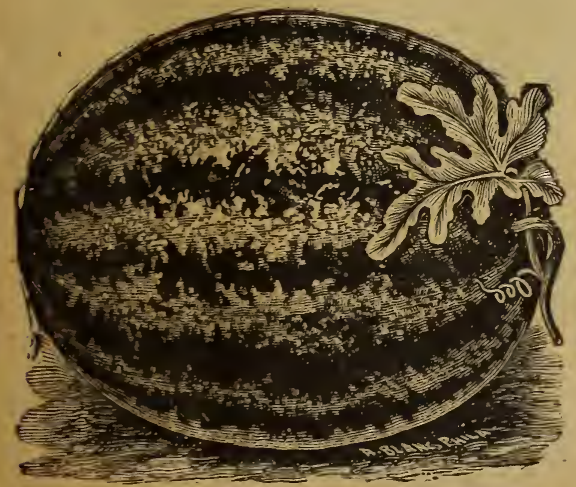

Kolb's Gem. rains at the time of ripening will destroy the flavor of the finest stock.

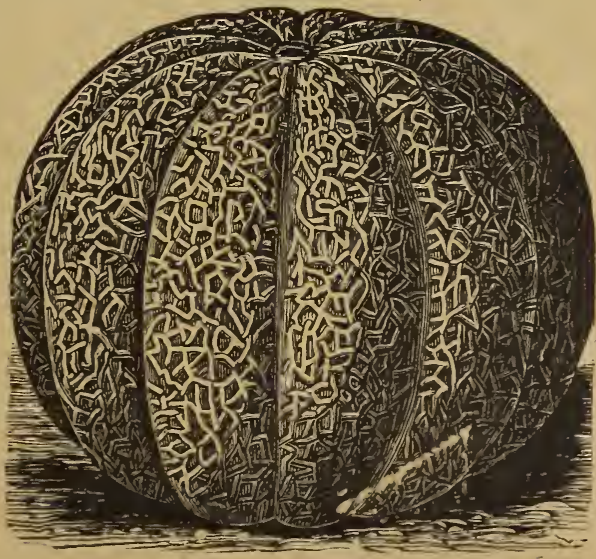

New Early Hackensack. 


\section{Melon, Musk.}

Bay View.-One of the largest, best flavored and most prolific of all varieties. Flesh rich, green, juicy and sweet. Often weighs ten to fifteen pounds. Pkt., 5c., oz., 15c.; 2 oz., 20c.; $\frac{1}{4}$ 1b., 30c.

Emerald Gem.-The highest flavored, red-fleshed melon. It is medium-sized, round and thick-fleshed. Pkt., 5c.; oz., 15c.: 2 oz., 20 c., $\frac{1}{4}$ 1b., 30 c.

Hackensack.-Fruit very large, flattened, with deep ribs; flesh thick, deep green, and of the finest flavor. Pkt., 5c.; Oz., 15c.

\section{melon, Water.}

Culture.-Water melons require a light, sandy soil, not very rich. Plant them in hills are directed for Cucumbers, except that they should be ten feet apart and a liberal dressing of ashes should be well mixed with the soil.

Phinney's Early.-One of the earliest varieties, and yields abundantly. Flesh light red or pink; very sweet and delicious. Pkt., 5c.; oz., 15c.; 2 oz., 20c.; $\frac{1}{4} 1 \mathrm{~b} ., 30 \mathrm{c}$.

Peerless.-This is unquestionably the best water melon in cultivation. Of medium size, thin rind, light mottled green, fresh bright scarlet, solid to the centre, crisp, melting, and sweet as honey. Pkt., 5c.; oz., 15c.; 2 oz., 20c.; $\frac{1}{4}$ lb., 30 c.

Kolb's Gem. - A very distinct variety Vines remarkably vigorous and healthy; leaves of medium size, deeply cut, with a peculiar frilled edge. Fruit the largest, round or slightly oval, marked with dark or light green in sharp contrast, giving it a bright and attractive appearance. Outer rind exceedingly hard and firm. Flesh bright and extending to within half an inch of the rind, always solid, very firm, sweet and tender. Pkt., 5c.; oz., 15c.; 2 oz., 20c.; $\frac{1}{4}$ 1b., 30c.

\section{Mustard.}

Culture.-This salad is cultivated like Cress; sow every week or two, in beds or drills, or for early use in hot beds, or in boxes in the windows of a warm room. The seeds should be covered very slightly, and frequently watered, as moisture is indisfensable to their growth.

White English.-The kind usually preferted for salad. Leaves light green, mild and tender, seed light yellow. Pkt., 5c.; oz., 10c.; 2 oz., 20c.; $\frac{1}{4}$ lb., 30c.

Try a Package of our BIRD SEED.

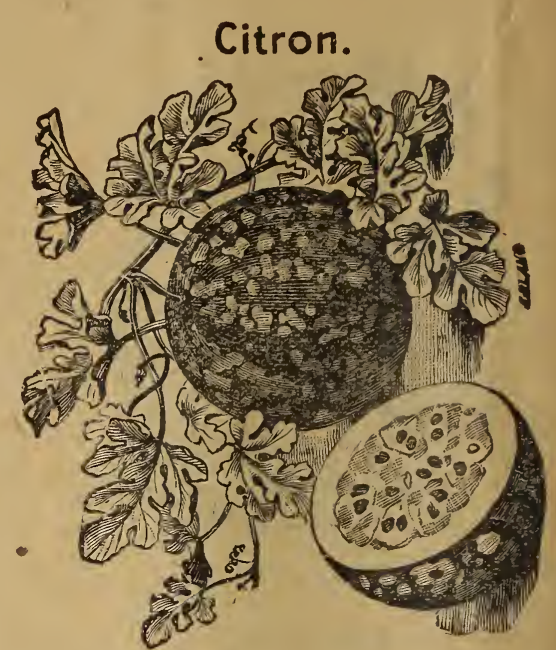

For Preserves.-It is rounded and smicoth, striped and marbled with light gicen, flesh white and solid, seeds red, should not be planted near other varieties, as it will destroy their flavor by hybridizing. Pkt., 5c.; oz., 15c.; 2 oz., 25c.; $\frac{1}{4}$ lb., $40 \mathrm{c}$.

Colorado Preserving.-Of large size, very productive and of excellent quality; green seed. Pkt., 5c.; oz., 15c.; 2 oz., 30 c.; $\frac{1}{4} 1 \mathrm{~b} ., 40 \mathrm{c}$.

\section{Mushrooms.}

The Mushroom is an edible fungus, of white color, changing to brown when old. The gills are loose, of a pinkish red, changing to liver color. It produces no seed,

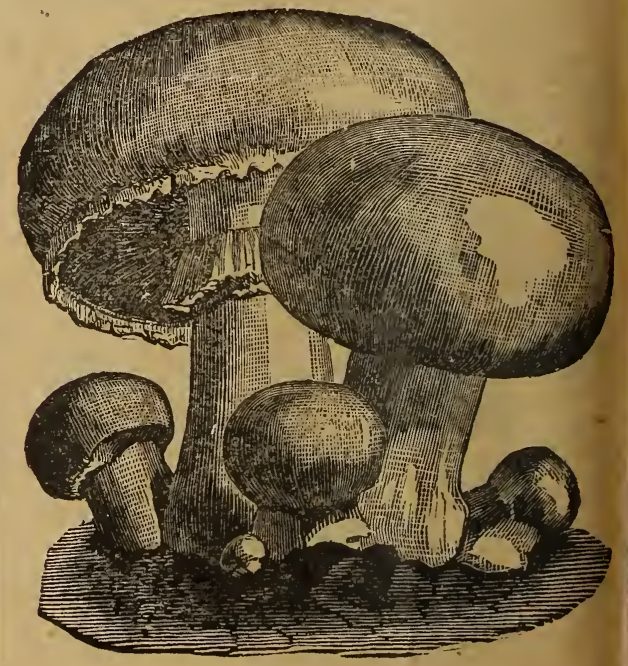


bit instead a white fibrous substance in broken threads, called spawn, which is preserved in horse manure, being pressed in the form of bricks. Thus prepared it will retain its vitality for years. In bricks, 25c.; by mail, $30 \mathrm{c}$.

Culture--Mushrooms can be grown in the cellar, in sheds, or in hot beds, in cipen air. on shelves or out-of-the-way places. Fermenting horse manure, at a temperature of about 70 degrees, is made in ( ) beds the size required, eighteen inches deep. In this bed, plant the broken picces of spawn six inches apart, covering the whole with two inches of light soil, to pretect from cold and severe rains. The muschrooms will appear in about six weeks. - Water sparingly and with lukewarm water.

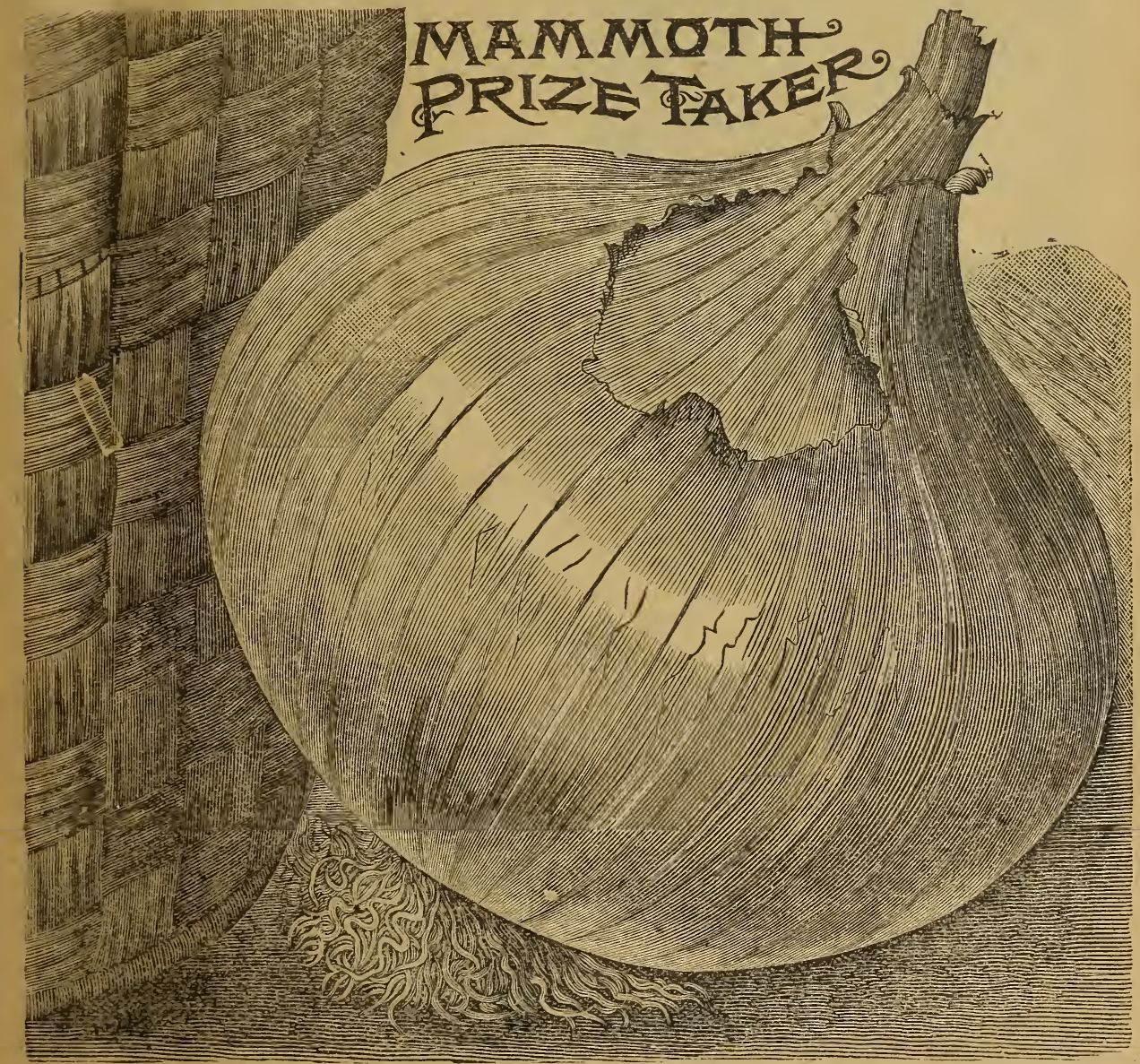

\section{Onions.}

"Prize Taker."-This is the large, beautiful Onion that is seen every fall offered fo: sale at the fruit stores in large cities. They are a rich straw color and of enormous size, averaging 12 to 14 inches in circumference. Although of such great size, it is very hard and an excellent keeper. The flavor is mild, making the "Prize Taker" a favorite variety for slicing salads. Pkt., 5c.; oz., 20c.; 2 oz., 35c.; $\frac{1}{1 b}$., 60 c.; lb., $\$ 2.00$. 


\section{Onions.}

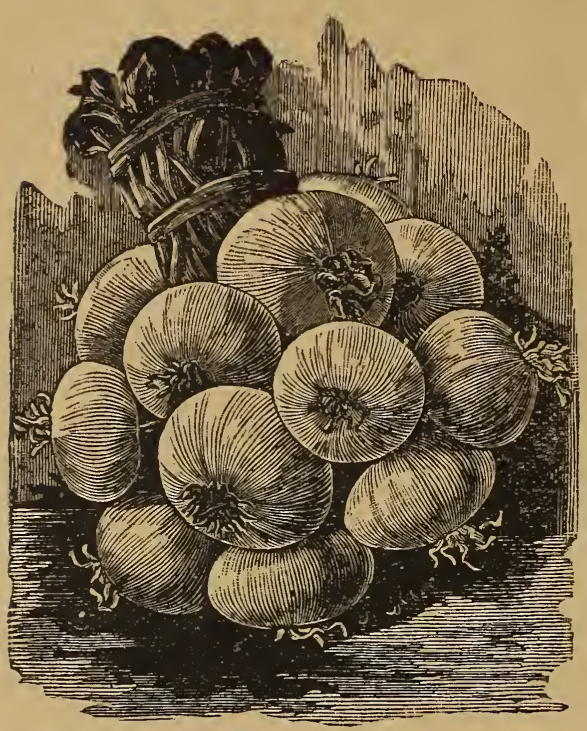

Extra Early Fed.-Two weeks earlier than the large red Wethersfield. Of medium size, flat, and produces abundantly. Pkt., 5c.; oz., 20c.; 2 oz., 3lc.; $\frac{1}{4}$ lb., 50c.; lb., $\$ 1.75$; by mail, $\$ 1.80$.

Large Red Wethersfield.-This is the standard variety. Large sized, skin deep purplish red; moderately fine grained and strorger flavored than any of the other kinds. Very productive, the best keeper, and popular for general cultivation. Pkt., $5 \approx$; oz., $15 \mathrm{c}$.; 2 oz., 25 c.; $\frac{1}{4}$ lb., 40c.; lb., $\$ 1.50$; by mail, $\$ 1.55$.

True Yellow Danvers.-A fine variety, originated in South Danvers, Mass. Above medium size, globular; skin yellowish brcwn, flesh white, sugary, comparatively mild and well flavored; a good producer, frequently yielding six hundred bushels to the acre, from seed sown in the spring. Plit., 5c.; oz., 15c.; 2 oz., 25c.; 1 1b., $40 \mathrm{c}$; lb : $\$ 1.50$; by mail, $\$ 1.55$.

White Globe.-Yields abundantly, producing handsome, globe shaped bulbs. Flesh firm, fine grained and of a mild flavor. Pkt., 5c.; oz., 20c.; 2 oz., 35c.; $\frac{1}{4}$ lb., 65c.; 1b., $\$ 2.50$.

Barletta Pickling.-This is a small, puse white variety, and very early. The onicins have a very delicate silver skin. Flesh firm and very mild. Its extreme earliness makes it one of the most valuable sorts yet introduced. For pickling purposes it has no equal. Pkt., 5c.; oz., 2zc.: 2 oz., 45c.; $\frac{1}{4}$ lb., 70c.; 1b., $\$ 2.50$.

Round White Silverskin for Pickling. - This is a small size, silvery white, and desirable for pickling. Pkt., 5c.; Oz., 20c.;

The Australian Brown Onion is of medium size, wonderfully hard and solid, and most attractive for market, both as to form and appearance. They are extremely early in ripening, and never make any stiff-necks or scallions. Every seed seems to produce a good-sized onion, and the bulb begins to form very quickly-when the plant is not over three inches high. Planted with Red Wethersfield, it proved to be nearly four weeks earlier and ripened off more uniformly. It has the reputati n of keeping indefinitely, and we think from its firmness and hardness that it will keep in good condition longer than any other Onion known. The color of the skin is a clear amber brown. So widely ccntrasted from any other Onion is this cclor that it will be noticed on market, and when once bought, purchasers will be most likely to return and call again for "those beautiful brown onions." Pkt., 5c.; oz., 20c.; 2 oz., 35c.; $\frac{1}{4} 1$ b., 60c.; 1b., $\$ 2.00$; post paid, $\$ 2.05$.

Onion Sets. $\quad$ Per lb. By mail.

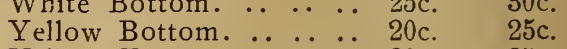

Yellow Tops ... ... ... 30c. 35c.

Pctato Onions........ 10c. 15c.

Shallots . . . . . . . 10 c. 15c.

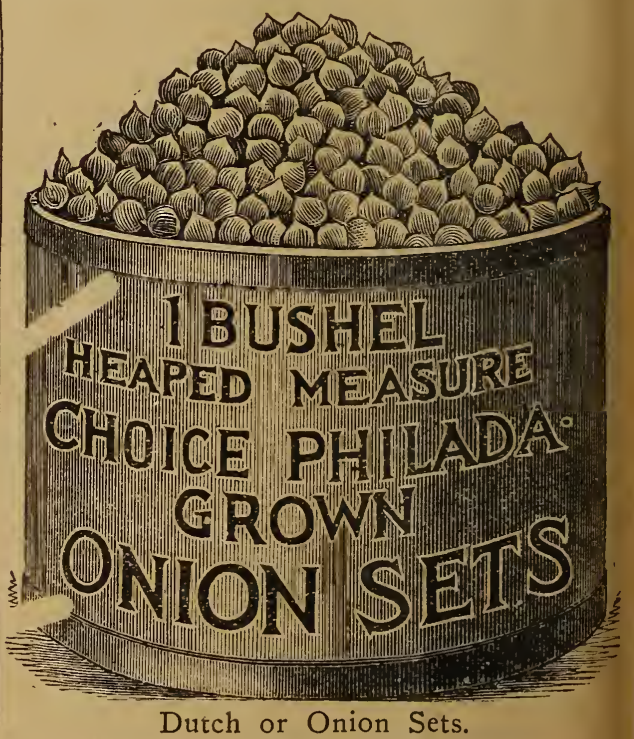




\section{Onions.}

Mammoth Silver King.-This variety has been extensively cultivated in the West and Northwest for the past five years, and has given perfect satisfaction. The skin is silvery white, and the flesh a pure white; very thick through and of a particularly mild and pleasant flavor. It cannot be too highly recommended for fanily or market use. Single bulbs of this variety have grown to weigh four pounds. Pkt., 5c.; oz., 20c.; 2 oz., 35c.; $\frac{1}{4}$ lb., 60c.; lb., $\$ 2.25$.

\section{Parsley.}

Fine Triple Curled or Myatt's Garnishing.-A fine free-growing but not larg, variety. The leaves are so abundant and so finely curled as to cause the plant to resemble a bunch of moss. Bright green and very hardy. One of the best. Pkt., 5c.; oz., 10c.; 2 oz., 15c.; 孝 1b., $25 \mathrm{c}$.

Champion Moss Curled.-Pkt., 5c.; oz., 10c.; 2 oz., 15c.; $\frac{1}{4}$ 1b., 25 c.

Carter's Fern Leaved.-Its finely divided leaves resemble some of the colored ferns and are so beautiful as to entitle it

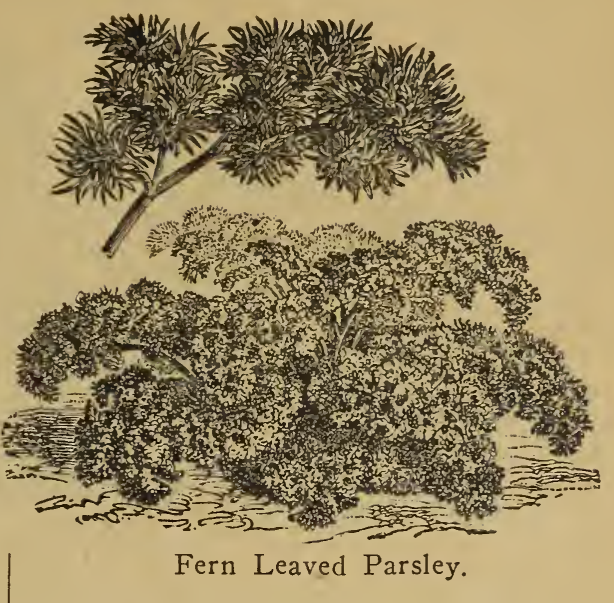

to a place in the flower garden. Pkt., 5c.; oz., 15c.; 2 oz., 25c.; 4 lb., $40 \mathrm{c}$.

Turnip Rooted, or Hamburg.-The edible root, which resembles a small parsnip, is extensively used for flavoring soups. Pkt., 5c.; oz., 10c.; 2 oz., 15c.; $\frac{1}{4} 1 \mathrm{~b}$., 25 c.

\section{Parsnip.}

Hollow Crown.-Root oblong, has a very smooth, clean skin, and is easily distinguished by the leaves arising from a cavity on the top of the root. Pkt., 5c.; Oz., 10c.; 2 oz., 15c.; $\frac{1}{4}$ 1b., 20c.; 1b., 70c.; by mail, $75 \mathrm{c}$.

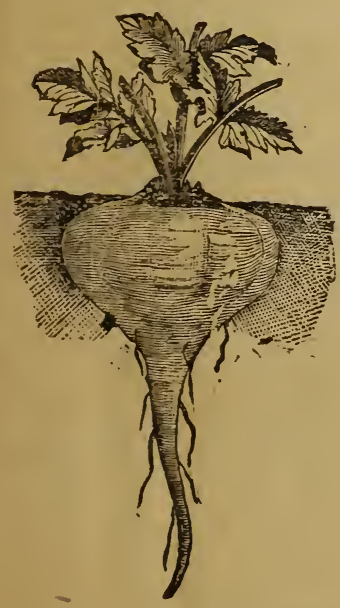

Early Short Round Parsnip.
Improved Guernsey, or Half Long.A very fine and improved strain which has given general satisfaction. The roots do not grow so long as the Hollow Crown, bist are of greater diameter and more easily gathered. The roots are very smooth, the flesh fine grained and of excellent quality. Pkt., 5c.; oz., 10c.; 2 oz., 15c.; $\frac{1}{4}$ lb., 2 ijc.; lb., 70c.; by mail, $75 \mathrm{c}$.
Early Round.-A short variety; crown broad and rounded; some hollow at the insertion of the leaves; very fine flavored. Pkt., 5c.; oz., 10c.; 2 oz., 15c.; $\frac{1}{4}$ lb., 20c.; 1b., 75c.

\section{Northern-Grown Seeds \\ are superior to Others.}

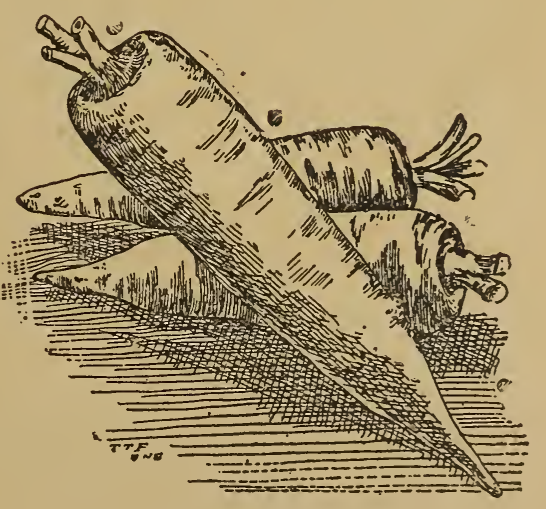

The Improved Guernsey. 


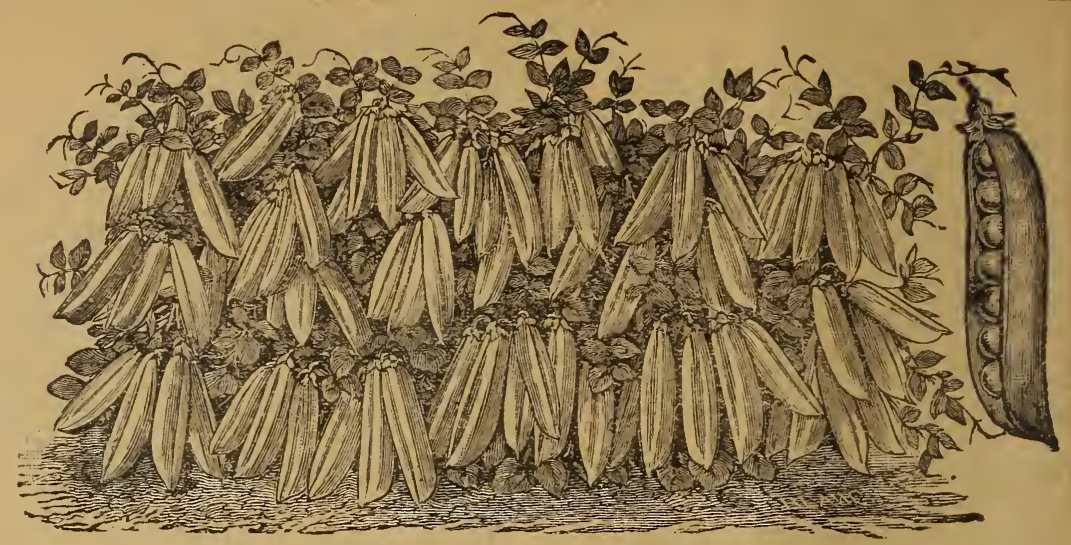

Bliss" American WVonder.

\section{PEAS.}

Persns' Extra Early Peas.-Earliest variety in cultivation. The finest extra early pea ever offered, and by far the most profitable for market gardeners to grow, as it comes into bearing earlier than any other variety, and therefore commands the very highest prices. Not only is it the ear.iest pea grown, but it is also a most wonderful bearer and ripens so evenly thet frequently the entire crop may be gathered at one picking. Grows to a lieight of about two feet, and produces pods of good size, which are filled with round peas of the finest quality. In fact, all that can be desired in a pea for both market and private use. Pkt., jc.; lb., 20c. : by mail, $25 \mathrm{c}$.

First and Best.-A selection from the EARLIEST RIPENING PEAS.-About 4.5 days from planting is the average time for ripening the whole crop. Decidediy the best variety for market gardeners' use. Pkt., 5c.; 1b., 20c.; by mail, 2.5c.

Bliss' American Wonder.-The stout. branching vines grow only about nine inchis high, and are covered with long, well filied pods; these contain seren or eight large, sweet, tender and well-flavored peas. Pkt.. 5c.; lb., 20c.; by mail, 25̌c.

Extra Early Tom Thumb.-Nine inches ligh, very productive. May be cultivated in rows ten inches apart. Pkt., 5c.; 1b., $15 \mathrm{c}$; by mail, $20 \mathrm{c}$.

Heroine.-In every way worthy the grcat popularity it has already attained. Elegant habit of growth, luxuriant foliage, pods remarkably long and handsome. slightly curved, well filled with large, luscious peas of fine flaror, a gem of the first water, apparently as good as Stratagem for all purposes, while far superior to the variety in habit, as it is remarkably true and fixed in its habits of growth. Height two feet; seed green and very much wrinkled. Pkt., 5c.; 1b., 20c.; by mail, 25c.

Large White Marrowfat.-An American variety, about five feet high, of strong growth. Pods large, round and well filled. seed: large and round. Excellent for sumniter use, and undoubtedly the greatest bearer. Pkt., 5c.; 1b., 10c.; by mail, 1x.

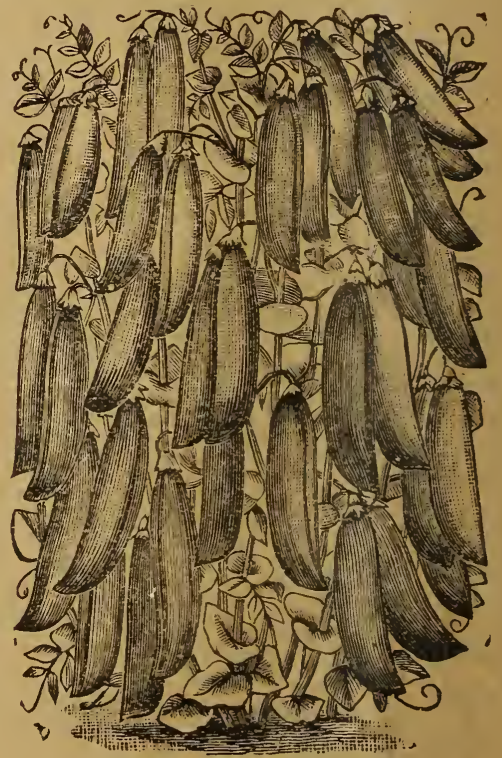

First and Best 


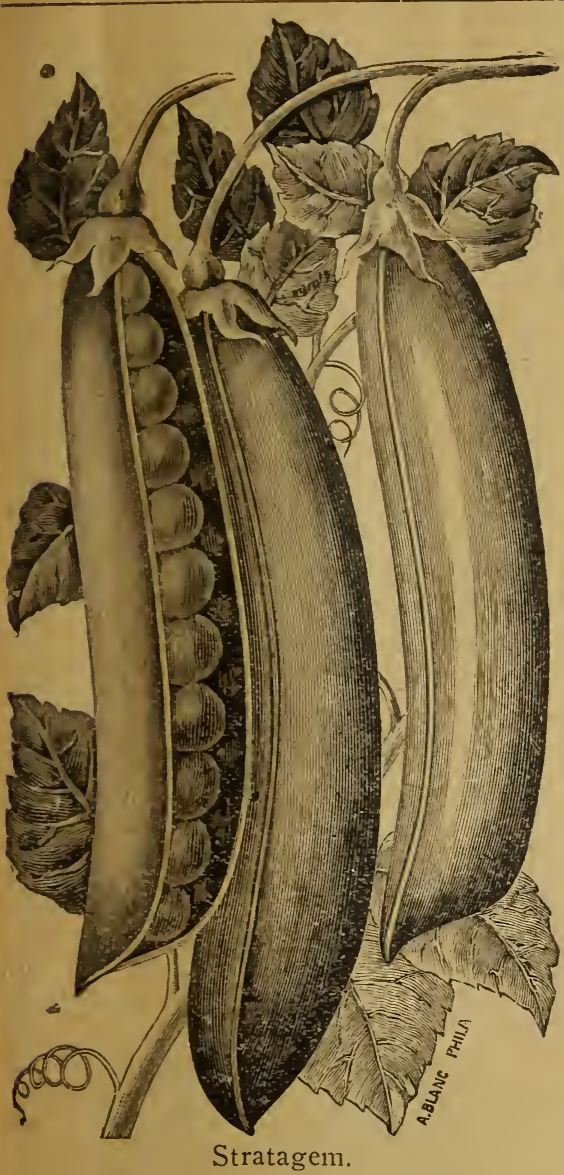

Stratagem.-A popular English variety bearing many large showy pods. Pkt., 5c.; 1b., 20c.; by mail, $25 \mathrm{c}$.

Dwarf Sugar. - Pods eatable, very swcet. two feet high, can be used in green state like string beans. Pkt., 5c.; $\frac{1}{4} \mathrm{lb}$., $10 \approx$ : 1b., 25c.; by mail, $30 \mathrm{c}$.

Blue Peter.-A blue Pea, as divarf as the Tom Thumb, and a great producer. Excellent in all respects. Pkt., 5c.; 1b., $20 \mathrm{c} .:$ by mail, $25 \mathrm{c}$.

Pride of the Market.-Vines of medium height, stiff, with large dark green leaves, and bearing at the top. generally in pairs, a fair crop of very large, dark grter: pods, well filled with large peas of good flavor. This has become very popular on account of its handsome pods, and is one of the few English peas which do well in this country. Pkt., 5c.; 1b., 20c.; by mail, $25 \mathrm{c}$.
Champion of England.-One of the richest and best flavored peas grown, and very productive. Height from four to five ferst, in quality equal to any in cultivation. Pkt., 5c.; 1b., 20c.; by mail, 25 c.

Yorkshire Hero.-A fine, white, wrinklea pea, very prolific, and of delicious flavor. It keeps a long time in season; and is unsurpassed in sweetness and delicate flaver. Pkt., 5c.; 1b., 20c.; by mail, $25 \mathrm{c}$.

Large Black-Eyed IMarrowfat-Grows abcut five feet high, pods large and full, a prolific bearer, and one of the very best Marrowfat varieties. Pkt., 5c.; 1b., 10c.; by mail, $15 \mathrm{c}$.

McLean's Little Gem.-This variety is dwarf and green wrinkled. When in a green state the peas are very large and of delicious flavor, being full of rich saccharine matter. It is one of the earliest varieties; grows about 16 inches high. Pkt. 5c.; lb., 20c. ; by mail, $2 \tilde{c}$.

\section{Pumpkin.}

Jumbo.-This is the variety to be grown where "the biggest pumpkin" is wanted. Specimens have been grown weighing 250 pounds. The color of skin is a deep yellow, the flesh being of a lighter shade. Notwithstanding its enormous size, it is delicious in quality and generally desirable. Pki., 5c.; oz., 25 cents.

Large Yellow.-Grows large and is adapted for cooking purposes and feeding stcck. It is irregular in shape and size, some being flattened at the ends, others round or long; of deep, rich yellow color, fine gain and of excellent flavor. $\mathrm{Pkt}$., 5 z.; oz., 10c.; 2 oz., 15c.; $\frac{1}{4}$ lb., 30c.

Sweet Cheese or Kentucky Field.By far the best variety for planting in the Scuth. Large, oblong, mottled, light green and yeliow, with very thick, sweet, tender, yellow flesh. Pkt., 5c.; Oz., 10c.; 2 oz., 15c.; 1 1b., 30c.

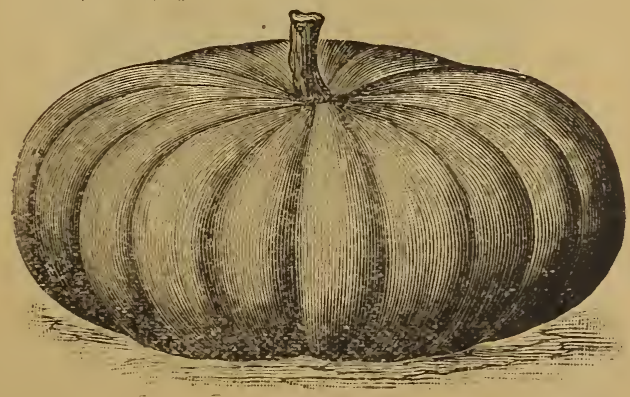

Sweet Cheese Pumpkin. 


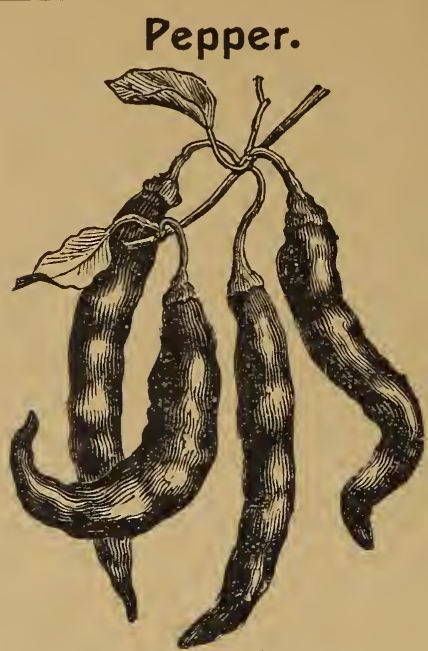

Long Red Cayenne.

Long Red Cayenne.-A long, slim pod, bright red when ripe, extremely strong and pungent. Pkt., 5c.; oz., 40c.

Mountain Sweet.-Plants very vigorous and productive. Fruit very large, often eight inches or more in length by two or three in diameter, very smooth and handsome, being when unripe of a deep green color, and when mature of a rich red. Flesh very thick, sweet and mild flavored. Well suited for a stuffed pickle. Pkt., 5c.; oz., 40c.

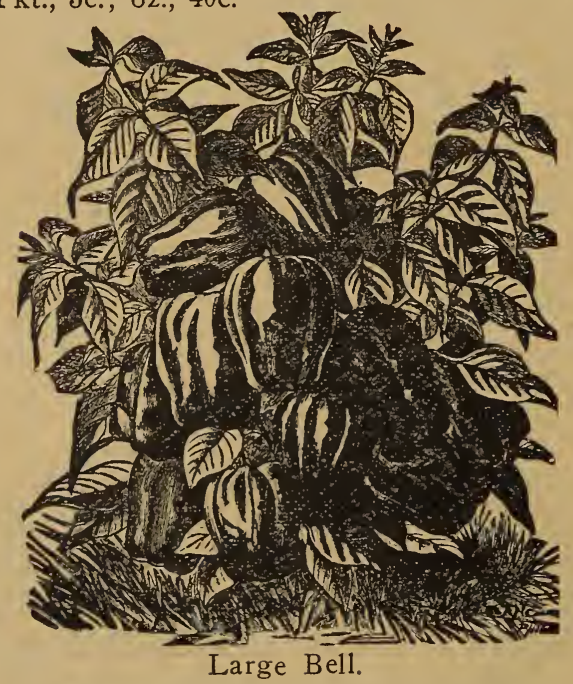

Large Bell or Bullnose.-A very large, square sort, mild, thick and hard; suitable for filling with cabbage, etc., for a stuffed pickle. Pkt., 5c.; oz.. 40c.

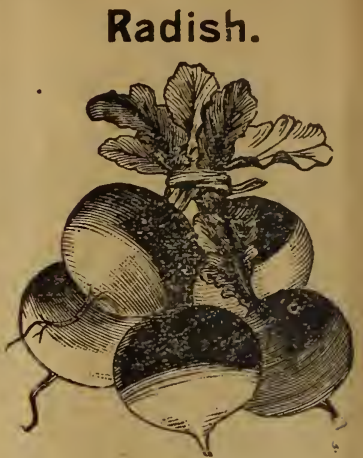

Scarlet Turnip, White Tip.

Early Scarlet Turnip, White Tipped. -Deep scarlet, with clear white tip. Very beautiful. Pkt., 5c.; oz., 10c.; 2 oz., 15c.; $\frac{1}{4}$ 1b., 25c.; lb., 75c.

Non Plus Ultra.-The smallest topped and earliest forcing radish; will mature in eighteen to twenty days; quality fine. Pkt. 5 c.; oz., 10c.; 2 oz., 15c.; $\frac{1}{4}$ lb., 25 c.; 1b, 75c.

Improved Chartier.-One of the best for early sowing out of doors; the roots come to unusual size very early, and remain hard and crisp until they reach a diameter of one and a half inches, and so furnish good roots one or two times as long as any of the above. Roots scarlet rose above, shading into white at tip; crisp and mild flavored. Pkt., 5c.; oz., 10c.; 2 oz., 15c.; $\frac{1}{4}$ lb., 25c.; 1b., $75 \mathrm{c}$.

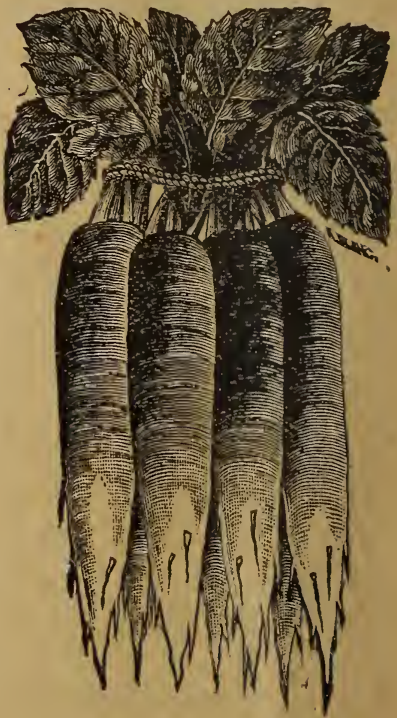

Chartier Radish. 


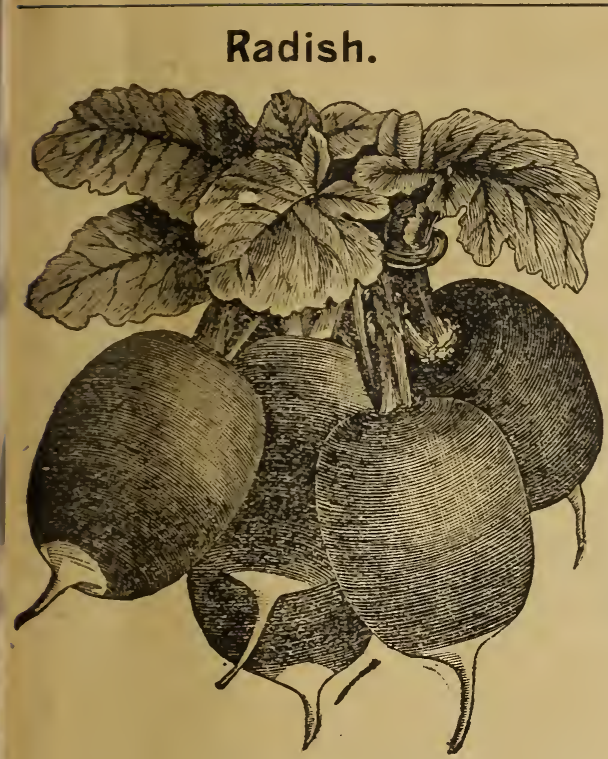

French Breakfast Radish.

French Breakfast.-Medium sized,oval, small top, of quick growth, very crisp and terider, of a beautiful scarlet color, except near the root, which is pure white. A spiendid variety for the table on account of its excellent qualities and is beautiful color. Pkt., 5c.; Oz., 10c.; 2 oz., 15c.; $\frac{1}{4}$ lb., 25c.; 1b., 80c.

Early Scarlet, Olive Shaped.-In the form of an olive. Skin fine scarlet, neck str:all, flesh rose-colored, tender and excellent. Early and well adapted for forcing or general crop. Pkt., 5c.; oz., 10c.; 2 cz., 15c.; $\frac{1}{4}$ 1b., 25c.; 1b., 90c.

Early Long Scarlet Short Top Improved.-Grows six or seven inches long, is very brittle and crisp and of quick grow th, color scarlet, small top. Suitable for forcing. Pkt., 5c.; oz., 10c.; 2 oz., 15c.; $\frac{1}{4}$ lb., 25c.; 1b., 75c.

Early Scarlet, Turnip Rooted.-Small red turnip-shaped, with a small top and of very quick growth. Pkt., 5c.; oz., 10c.; 2 oz., 15c.; $\frac{1}{4}$ lb., 25c.; 1b., $75 \mathrm{c}$.

Early White, Turnip Rooted.-Like Early Scarlet, but pure white; flesh white and semi-transparent. Pkt., 5c.; oz., 10c.; 2 cz., 15c.; + lb., 25c.; 1b., 60c.

Early White, Olive Shaped.-Pkt., 5c.; oz., 10c.; 2 oz., 15c.; $\frac{1}{4}$ lb., 25c.; 1b., 80c.

Round Black Spanish.-Pkt., 5c.; oz., 15:.; 2 oz., 20 c.; $\frac{1}{4}$ lb., 30 c.
Long Black Spanish, Winter.-One of the latest and hardiest of the radishes. An excellent sort for winter use. Roots oblonE, black, large and firm. It is sown somewhat earlier than fall turnips, and must be kept stored in sand, in the cellar, for winter use. It will keep good till sprung. Pkt., 5c.; oz., 15c.; 2 oz., 25c.; $\frac{1}{2}$ lb., 35c.; lb., \$1.00.

California Mammoth White China, Winter.-Pure white, about one foot long and two or three inches through, tapering rcgularly to the root. The flesh is tender and crisp and it keeps perfectly through the winter. Pkt., 5c.; oz., 15c.; 2 oz., $20 \mathrm{c}$.

Horse Radish Seed.-Pkt., 5c.; oz., 15c.

\section{Spinach.}

Round Summer.-This variety is good for early sowing. Leaves large, thick and fleshy. Not quite so hardy as the Prickly, but stands the winter well. Pkt., 5c.; oz., 10 c.; $\frac{1}{4}$ lb., 20c.; 1b., 50c.

Improved Thick Leaved-An improvement on the last, with larger, thicker leaves, and slower to run to seed. $\mathrm{Re}-$ coinmended for market culture. Pkt., 5c.; oz., 10c.; $\frac{1}{4}$ lb., $20 \mathrm{c}$; ; lb., $50 \mathrm{c}$.

New Zealand - (Tetragonia).-Perenniai, fit for use the first year. Must be slightly protected during winter. Pkt., 5c.; oz., 20c.; 2 oz., 35c.; $\frac{1}{4}$ 1b., 60c.; lb., $\$ 1.25$.

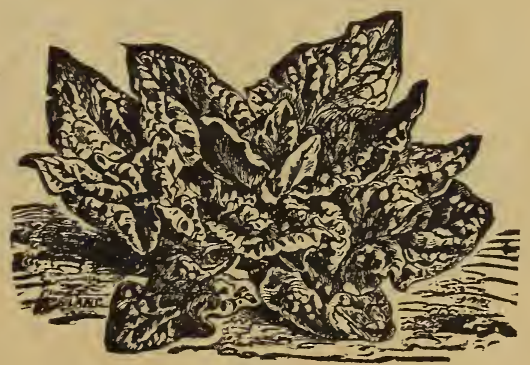

Long Standing Spinach.

Long Standing Prickly.-Furnishes a large quantity of very thick, well-flavored leaves. One of the best for market gardeners. Pkt., 5c.; oz., 10c.; 考 1b., 20c.; 1b., $50 \mathrm{c}$.

\section{Sunflower.}

Large Russian. - Extensively planted for feeding chickens. This is much superior to the common sort, as it forms a single, large flower, and the seeds are larger and richer in oil. Pkt., 5c.; lb., $10 \mathrm{c}$; 1b., $25 \mathrm{c}$; ; by mail, $30 \mathrm{c}$. 


\section{Rhubarb or Pie Plant.}

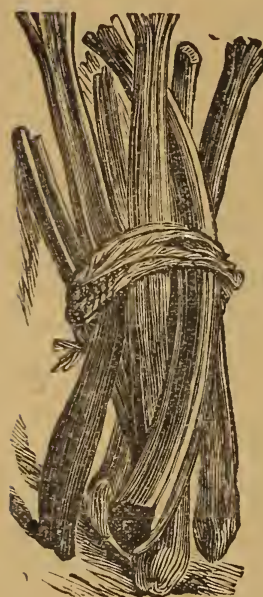

Victoria Rhubarb.

Giant.-A very late variety, with round stalks of great length and thickness. Produces a succession of stalks the whole season. Pkt. 5c; oz. $25 \mathrm{c} ; 2$ oz. $40 \mathrm{c}$; $\frac{1}{4} \mathrm{lb}, 75 \mathrm{c}$.

Victoria.-Pkt., 5c.; oz., 25 c.; 2 oz., 40 c; $\frac{1}{4}$ lb., $75 \mathrm{c}$.

Johnston's St. Martin.-Pkt., 5c.; oz., $2 \check{c}$. ; 2 oz., 40c.; $\frac{1}{4}$ lb., $75 \mathrm{c}$.

Early Raspberry.-Very fine. Pkt., 5c; oz., 30c.

\section{Salsify, or Vegetable Oyster.}

Mammoth Sandwich Island. - This variety is of enormous size, twice that of the ordinary Long White; pure white, ver; tender and delicious; invaluable for the market gardener. Pkt., 5c.; oz., $20 \mathrm{c}$.

Large White.-Pkt., 5c.; oz., 20c.

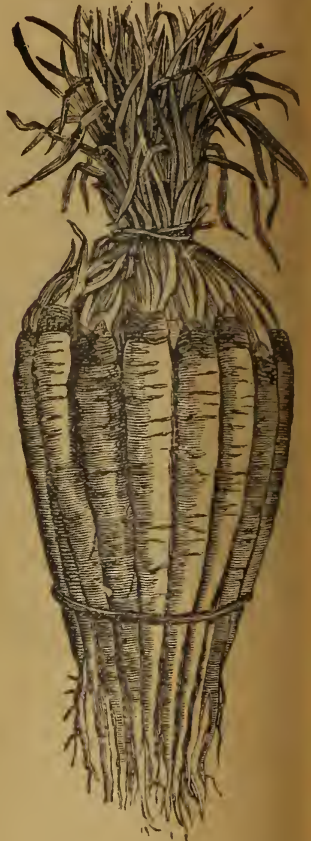

Long White Salsify.

\section{Squash.}

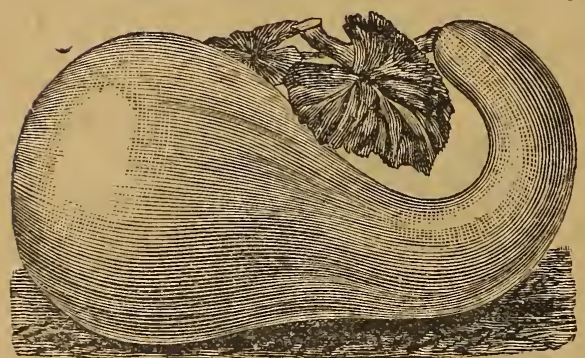

Summer Crookneck Squash.

Summer Crookneck.-The richest and best sort for summer; very early and productive. It is small, with crooked neck, covered with warty excrescences, the more the better. Color, bright yellow, shell very hard. Pkt., 5c.; oz., 10c.; 2 oz., 15c.; $\frac{1}{4} 1 \mathrm{~b} ., 30 \mathrm{c}$.

Large IMammoth Yellow Chili. Grows to an immense size, often weighing 200 lbs.; excellent for all uses. Pkt., 5c.; oz., 15c.; 2 oz., 25c.; $\frac{1}{4}$ lb., $40 \mathrm{c}$.

The preceding varieties may be planted five or six feet apart, as they do not form long vines, and the fruit should be picked before it commences to harden, in order to prolong the bearing season.
Summer Variety, Long White Bush Vegetable Marrow.-A decided improvemient on the old trailing vegetable marrow; the fruit is larger, handsomer, more ribbed or fluted, and of strictly bush form. Pkt., 5c.; oz., 15c.; 2 oz., 25c.

Hubbard.-This is a superior variety, and the best winter Squash known. Flesh bright orange yellow, fine grained, very dry. sweet and rich flavored, keeps perfectly good throughout the winter, boils or bakes exceedingly dry, and is esteemed by many to be as good baked as the swcet potato. Pkt., 5c.; oz., 10c.; 2 oz., $15 \mathrm{c}$; ; $\frac{1}{4}$ 1b., $25 \mathrm{c}$.

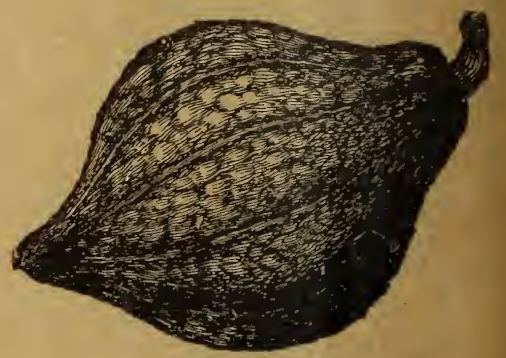

Hubbard Squash. 


\section{Squash.}

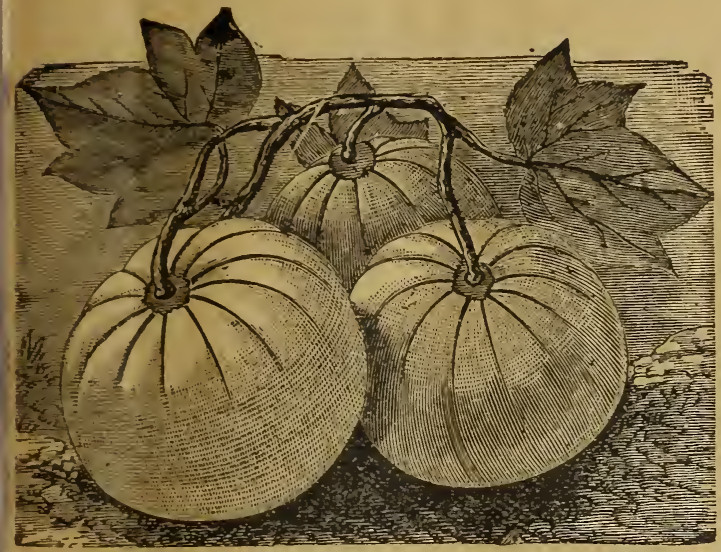

Perfect Gem Squash.

Perfect Gem.-Equally desirable either as a summer, autumn or winter squash. It is a strong grower and a large yielder. The Squashes are from four to six feet in dian,eter, of a creamy white, with thin, snicoth shell, slightly ribbed. The flesh. cocked, is dry, sweet and rich in flavor. and free from the strong taste often found in winter sorts. Pkt., 5c.; oz., 10c.

Boston Marrow.-Of oval form, skin thin, when ripe bright orange; flesh rich salmon yellow, unexcelled for sweetness, flavo: and fine grain. Pkt., 5c.; oz., 10c.; $2 \mathrm{cz.}, 15 \mathrm{c}$; $\neq 1 \mathrm{lb} ., 30 \mathrm{c}$.

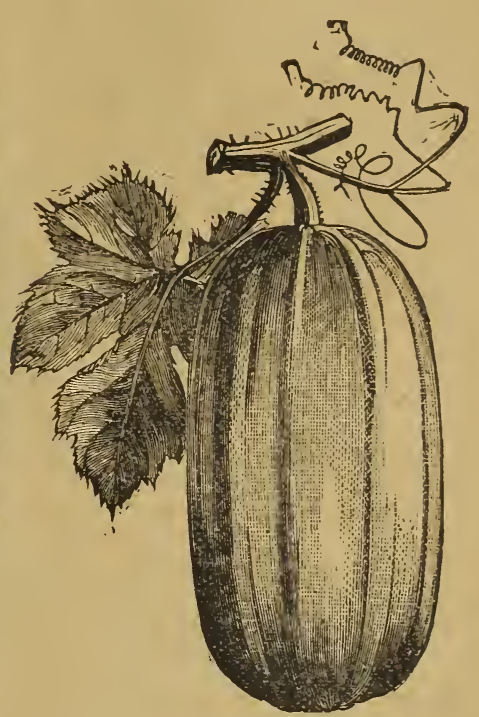

Vegetable Marrow (English).

English Vegetable IMarrow.-Fruit oblong in shape, 10 to 16 inches long, 4 to 6 inches in diameter; skin smooth and of a yellowish white color; flesh white, soit and rich flavored. Plant eight feet apart. Pkt., 5c.; oz., 15c.; 2 oz., $25 \mathrm{c}$; $\frac{1}{4}$ ib., $40 \mathrm{c}$.

\section{Tomatoes.}

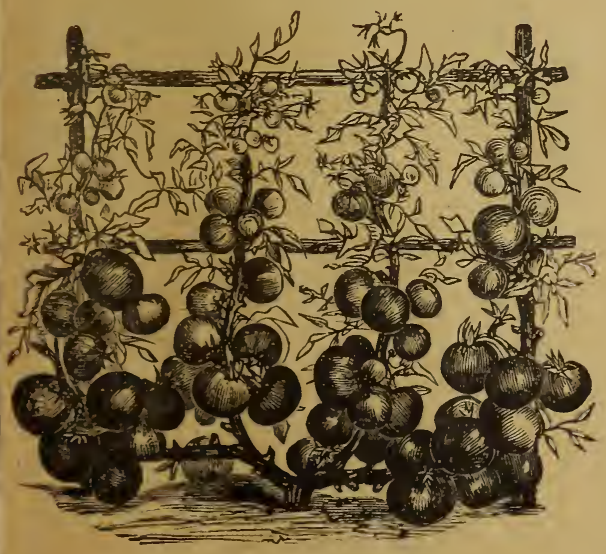

Culture.-The seeds should be sown in a hot bed in March, or in pots in a warm window. They should be started early, then forwarded as rapidly as possible, whether by hot bed or open air culture. as the least check in their growth would matcrially diminish the crop. When about two inches high they should be transplanted to sunny, light, rich soil. As soon as the ground is warm and danger of frost is over, harden off the plants by full expcsure to the sun, giving little water for a few days, and then set out three or four feet apart. The fruit will be better and less liable to rot if the plants are trained upon trellis work, or supported by driving stakes in the ground and $t y^{-}$ ing to them.

Canada Victor.-Very early, of thin skin, solid, with few seeds, round and Canada Victor. smceth; ripens and colors to the stem. $\mathrm{Gc,od}$ for home market. Pkt., 5c.; oz., 30c. 
Acme.-This is one of the best varieties. Fruit of medium size, perfect form, round, slightly depressed at the ends and very smooth. Color dark, glossy red, with light purplish tinge. Ripens all over and through at the same time, has no green core and but few seeds; bears continually till frost comes. Excellent for market use, for canning purposes or for shipping. Pkt. 5c.; Oz., 30c.

Yellow Cherry.-Differing from Red only in color. Pkt., 5c.; Oz., 50c.

Ground Cherry, or Husk Tomato. - This is much liked by many for preserves and for eating from the hand. The seed that we offer is that of the

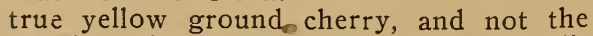
purple fruited sort, which is scarcely edible. Pkt., 5c.; oz., $60 \mathrm{c}_{\text {i }}$
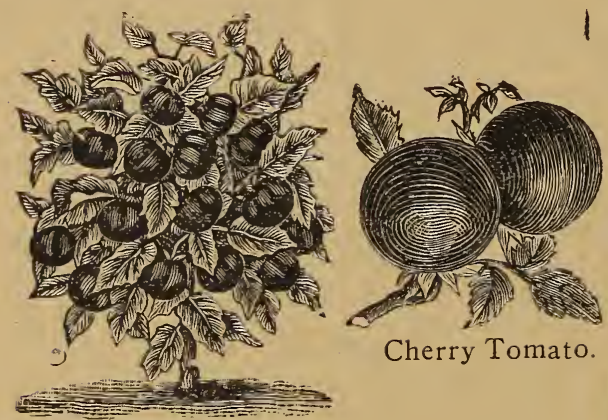

New Dwarf Champion.

New Dwarf Champion.-One of the most distinct and valuable Tomatoes. Dwarf, stiff habit, scarcely needing any support. Very early and wonderfully prolific. Color rich bright scarlet. Is perfectly round and smooth, of medium size, cortaining few seeds, and is really more "meaty" than many Tomatoes twice the size (see cut). Pkt., 5c.; oz., 30c.

Early Conqueror.-The product of one acre of this variety has been over one thousand bushels of Tomatoes, all put into market before most other sorts begin to ripen. It is a large producing, well formed, smooth, handsome, early Tomato for market or family. Pkt., 5c.; oz., 30c.

Red Cherry.-Fruit small, about $\frac{5}{8}$ of an inch in diameter, perfectly round and smooth. Fine for pickles and preserves. Pkt,, 5c.; oz., 50c.

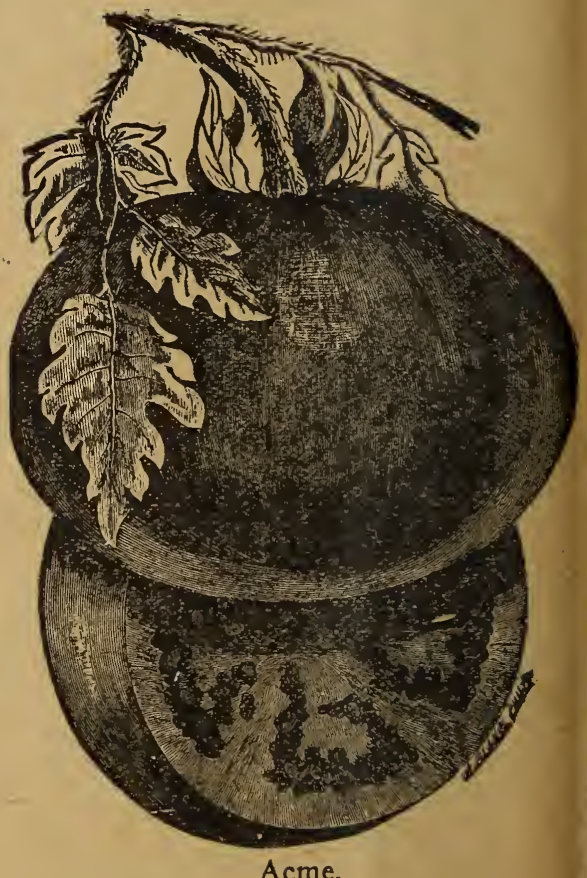

Acme. 


\section{Turnip.}

Elephant, or Monarch Swede.-The new Swede was introduced into England five years ago, and has met with remarkable success there, reports from many sections proving it to be an immense crcpper, and it has won prizes wherever shcwn. We are pleased to be able to offei it to our Canadian customers as one werthy of trial. It resembles in shape the Golden Tankard Mangel; the flesh is

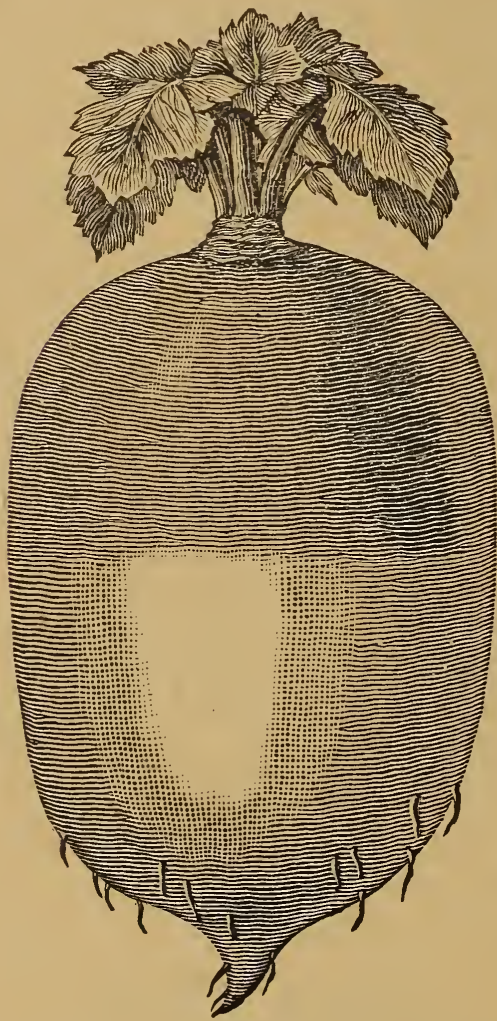

Monarch or Elephant Turnip.

rich. creamy yellow, and the crown of the root is a rich purple. Elephant Swede stands well out of the ground, and is a giant compared with many varieties. It is uniform in size, and is absolutely hardy. Pkt., 5c.; 1b., 40c.; by mail, 45c.

Carter's Imperial Hardy Purple Top Swede.-A most excellent sort for either table use or feeding stock. Flesh yellow, solid, firm, sweet and rich. It is a hardy sort, yields heavy, with no tendency to long neck. Pkt., 5c.; 市 lb., 10c.; 1b., 25c.; by mail, $30 \mathrm{c}$.

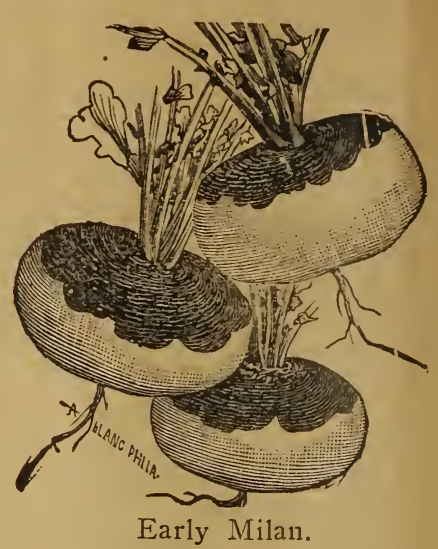

Extra Early Purple Top Milan.Forms bulbs the earliest of any sort. Roots very white, with clear purple top. The best for forcing. Pkt., 5c.; oz., 10c.; 2 oz., 15c.; 1 1b. 25c; 1b. 80 c.; by mail, 85 c.

Bangholm Swede.-A superior variety, of large size, yellow flesh, small neck, no side roots, and very productive. Pkt., $5 c$; 1b., 25c.; by mail, $30 \mathrm{c}$.

White Egg.-A quick-growing, eggshaped, pure white variety, of extraordinary firmness and solidity. Flesh sweet, fir $\mathrm{m}$ and mild. Pkt., 5c.; oz., 10c.; 2 oz., $15 \mathrm{c}$; $\frac{1}{4}$ lb., $25 \mathrm{c}$; 1 1b., 60 c.; by mail, $65 \mathrm{c}$.

\section{Scottish Cham-} pion Swede. - Fine la rge roots, and highly recommended for heavy soils. Pkt. 5c.; $\frac{1}{4}$ lb., 10c.; 1b., 25c.; by mail, 30c.

Sutton's Cham. pion Purple Top.One of the heaviest yielding varieties, and a general favorite. Pkt., 5c.; $\frac{1}{4} 1 \mathrm{lb} ., 10 \mathrm{c}$; lb., $25 \mathrm{c}$; ; by mail, 30c.

Highland Prize. A very heavy cropping Swede and an excellent keeper, the roots being of handsome oval shape, uniform size. Pkt., $5 c . ; \frac{1}{4}$ lb., 10c.; lb., $25 \mathrm{c}$; by mail, $30 \mathrm{c}$.

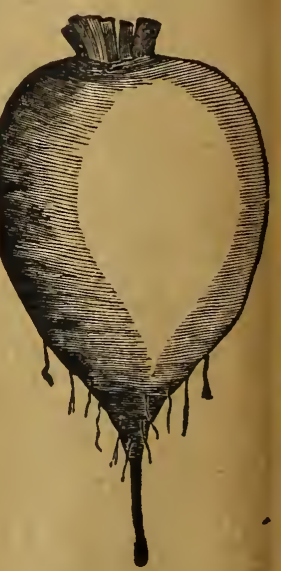

White Egg.
Mr. H. Poulter, Box 17, Grand Forks, B.C. writes: I write to ask you to send me a catalogue of your Seeds, as I had gcod results in Manitoba from your Seed, a'ld wish to get some more. 


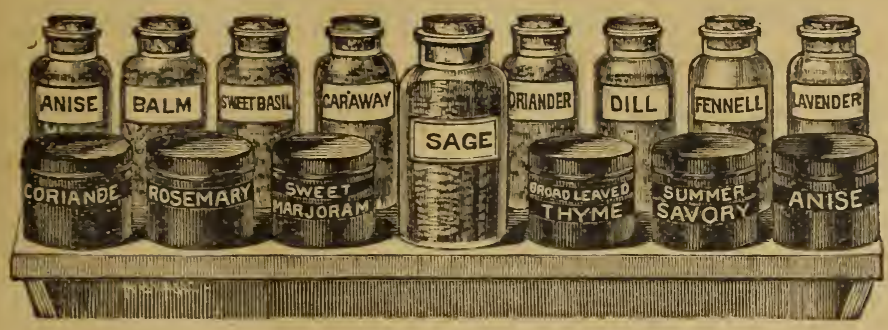

HERBS.

Anise.-A well known annual herb, whose seeds, which have an agreeable aroriatic odor and taste, are used for dyspef sia and colic, and as a corrective for griping and unpleasant medicines. Sow ea! ly and thin to three inches apart in the row. Pkt., ǰc.; oz., 20c.

Balm.-A hardy perennial. The leaves are used for various medicinal purposes. Plant ten inches apart, giving plenty of water, if dry. Pkt., 5c.; oz., 40c.

Basil, Sweet.-Sow early in spring, in drili? eighteen inches apart and six inches apart in the row. When three inches high thin to one foot apart. Pkt., 5c.; oz., 40c.

Borage.-Used as a pot herb. The young shoots are also boiled and used like spiriach. Sow in light, dry soil, early in sprirg, in drills one foot apart, and thin the plants to six inches. Pkt., 5c.; oz., 30c.

Caraway.-The seeds of this plant are much used in confectionery, cakes, etc. $\mathrm{S}, \mathrm{w}$ in spring or autumn. Pkt. $5 \mathrm{c}$; oz. $10 \mathrm{c}$.

Catnip.-A hardy perennial plant, the leaves of which are valuable as a mild nervine for infants. Sow the seeds in sping or fall, and give the plants a foot of rcom. Pkt., 5c.; oz., 75c.

Coriander.-Raised mostly for its seed, which have an aromatic taste and are used in confectionery. Sow early in spring, in drilis ten inches apart, and thin the plants to four inches. Gather on a dry day. Pkt. 5c.: oz., 10c.

Dill.-The seeds are used medicinally, and for culinary purposes Sow early in spring in drills eighteen inches apart, and thin the plants to six inches. Pkt., 5c.; oz. $20 \mathrm{c}$.

Fennell, Sweet.-A hardy perennial plint, the seeds of which are used for flavoring and also for medicinal purposes. Sow where it is to stand, in drills eighteen inches apart, and thin to six inches apart in the row. Pkt., 5c.; oz., 20c.
Horehound.-A well-known medicinal plant, which enters largely into the composition of cough syrups and lozenges. Sirw in spring in drills two feet apart and thin the plants to 1 foot. Pkt., $5 \mathrm{c}$; oz., $40 \mathrm{c}$.

Hyssop.-A medicinal plant, having a warm, pungent taste, the flowers are used fo: asthma and catarrh. Sow the seed in spring, in drills two feet apart, and give each plant twelve inches space in the row. Plit., 5c.; oz., 30c.

Lavender.-Cultivated for its fragrant flowers, which are used for the distillation of lavender water, as well as certain medicinal purposes. Sow in drills two feet apirt, and thin the plants to two feet in the rows. Pkt., 5c.; oz., 30c.

Marjoram, Sweet.-Used in soups, broths, dressings, etc. Sow in drills one foct apart, and thin the plants to ten inches apart in the drill. Pkt. 5c.; oz., 20c.

Rosemary.-A hardy perennial shrub, having a bitter taste, and used for various medicinal purposes. Sow in drills sixteen inches apart, and the following autuinn or spring transplant to fifteen inches apart each way. Pkt., 5c.; oz., 75c.

Rue.-A hardy perennial plant. It is a powerful medicinal agent and must be used with caution. Sow in drills eighteen inches apart, and thin plants to eighteen inches in the row. Pkt., 5c.; oz., 50c.

Saffron.-An annual plant, possessing many medicinal virtues. The flower is the part used, which should be picked and dried while in full bloom. Sow in drills eighteen inches apart, and thin to one foot apart in the row. Pkt., 5c.; oz., $40 \mathrm{c}$.

Sage.-A perennial plant, perhaps more widely known than any of the other herbs in its medicinal and culinary uses. Sow early in spring in drills sixteen inches apart: the following autumn or spring transplant into rows sixteen inches apart each way. Pkt., 5c.; oz., 20c. 


\section{Herbs.}

Savory, Summer.-A hardy shrub much cultivated for medicinal and culinary uses, its warm aromatic leaves being much esteemed in salads and soups. Sow in drills eighteen inches apart, and thin to one fo it apart in the row. Pkt., 5c.; oz., $15 \mathrm{c}$.

Tansy.-A hardy perennial plant, possessing the medicinal properties common to bitter herbs. Sow broadcast or in drills one foot apart, and thin to one foot apart in the row. Pkt., 5c.; oz., 50c.

Thyme.-A perennial herb, largely used for culinary purposes, and not unfrequent1y medicinally. Sow either broadcast or in drills six inches apart, and thin to six inches in the row. Pkt., 5c.; oz., 15c.; $\frac{1}{4}$ 1b., 35c.

Wormwood.-A perennial plant. Sow in drills eighteen inches apart and transplart to eighteen inches apart each way. A dry, poor soil is the best for this plant. Pkt., 5c.; oz., 50c.

Mint, package ..........10c.

Peppermint, package .. . . . ..10c.

Sorrel, package ... . . . . . . . 5c.

Pot Marjoram, package ... .. 5c.

Mr. Mike Sikora, Kaposvar P.O., Assa., writes: Be kind enough to send me the Seeds as ordered as soon as possible. Hcping to get as good Seeds as last year.

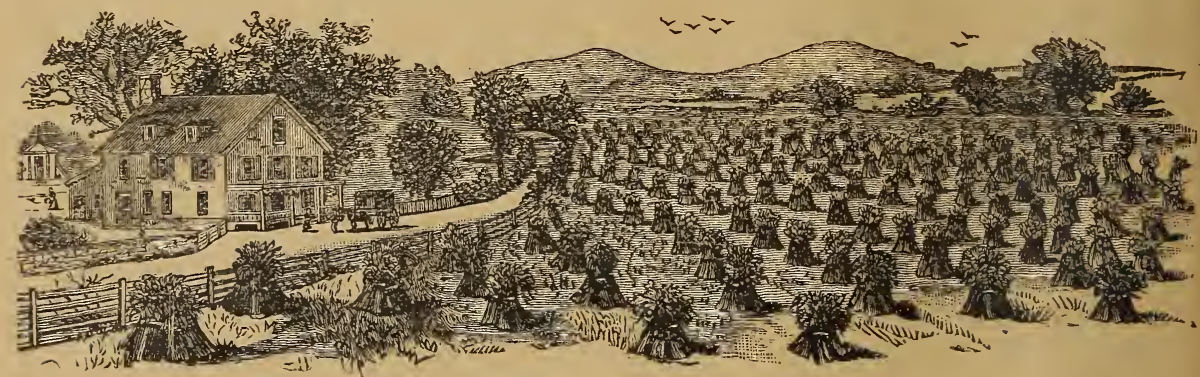

\section{Miscellaneous Farm Seeds.}

\section{Clover Seeds.}

There are no plants so valuable for fertilizers as the Clovers. They have the faculty of absorbing nitrogen from the air, and also rendering available much of the inert plant food of the soil. Their long, powerful tap roots penetrate to a dejth, loosen the soil, admit air, and by their decay add immensely to the fertility of the soil.

Medium Red, or June.-This is by far the most important of all varieties for the practical purpose of agriculture. Sow in spring or fall and when no other grasses are used, at the rate of eight or ten lbs. per acre, more being required on old stiff soils than on new and lighter ones. Sixty pounds per pushel. Lb., 20c.; by mail, $25 \mathrm{c}$.

White Dutch.-A small, spreading, creeping, perennial variety, valuable for pastire and for lawns. It accommodates itself to a variety of soils, but prefers moist ground. In conjunction with blue gross it forms the most nutritious grass for sheep or cows. Sow in spring at the rate of six lbs. per acre, or, when used with other grasses, half that amount will be sufficient. Lb., 30c.; by mail, 35c.

Bokhara Clover (Melilotus Vulgaris). - For bees. Of large and vigorous: growth; blooms early in August; may be cut three times during the season, and yie!ds from three tons upwards of hay per acre. For hay or fodder, cut when green; grows two feet high, has a white and very sweet scented blossom; most valuable for becs. Sow in spring. Per 1b., 20c.; postpaid, $25 \mathrm{c}$.

Alsike, or Swedish.-This valuable variety is fast gaining great popularity. It is the most hardy of all the Cloversperernial. On rich, moist soils it yields an enormous quantity of hay or pasturage and may be cut several times in a season, but its greatest value is for sowing with othe1 clovers and grasses, as it forms a thick bottom and greatly increases the yield of hay, and cattle prefer it to any other forage. The heads are globular, very sweet and fragrant, and much liked by bees, which obtain a large amount of 
honey from them. Sow in spring or fall at the rate of six lbs. per acre where used alc ne. Sixty lbs. per bushel. Lb., 20c.; bj mail, $25 \mathrm{c}$.

Lucerne, or Alfalfa.-Where this succeeds it is the most valuable of all clovers. It is more difficult to secure a good stand, as it requires very fine, mellow soil, and some protection the first year, but when onci established it will produce a profitable crop from five to twelve years. It yiclds a prodigious amount of green fodder for cattle, and should be cut when commencing to bloom, when it pushes out fresl: shoots, and the aftergrowth is something wonderful. In the driest and most sultry weather, when every blade of grass withers, Lucerne is as fresh and green as in spring, because the roots go down to the moisture in the ground. Although such a prodigious yielder, it does not exhaust the soil, but rather improves it. It should be sown on compact, clay soil, even with a light subsoil. Lb., 20c.; by mail, 25c.

Sainfoin.-An excellent perennial fodd:r plant, grows to a height of about three feet and flowering in June or July. It stands improving by age. It is naturally adar.ted for light, chalky soil, being an enriching, heat-resisting clover, and may be sown either broadcast or drilled. If the broadcast system of sowing is preferred it will require about five or six bushels per acre; if drilled, four or five bushels. It will crop from seven to ten years, according to the nature of the soil. Lb., $20 \mathrm{c}$; ; by mail, $25 \mathrm{c}$.

Red Top.-In some sections this is called Rhode Island Bent Grass. In Pennsylvania and States further south it is known as Herd's Grass, a name applied in New England and New York to Timothy. It is a good permanent grass, standing our climate well, and makes a good pasture when fed close. It is valuable for low wet meadows, producing a large return in hay. When sown alone, two bushels per acre are required, sown in spring or fall. 14 lbs. per bushel. Lb., 20c.; by mail, 25 c.

Kentucky Blue Grass.-This is known in some sections as Green Meadow Grass and June Grass, but should not be confor nded with Poa Compressa, called by some June Grass or Wire Grass. This spccies produces the most nourishing food for cattle of any kind, and till a late periol in winter, and in the south abundant focd throughout the winter. In conjunction with White Clover, it forms the finest and closest of lawns; for this purpose an extra quantity of seed should be used, say four bushels of Blue Grass and six pounds of White Clover per acre. If sown by itself for pasturage, two bushels will be re quired, sown in early spring or in October or November. 24 lbs. per bushel. Lb., 20 c.; by mail, $25 \mathrm{c}$.

Extra Fine Mixed Lawn Grass (Central Park Mixture).-The essentials for 2 fine lawn are proper drainage, a careful preparation of the soil, which should be made as fine and light on the surface as possible; thorough rolling, and a selection of the seeds of such grasses as will promote a luxuriant verdure from early spring to late in the autumn, and then frequent mowing with a lawn mower. However mutch care is bestowed on the soil and seed, no lawn will be beautiful without frequent mowing and rolling. If sown in the spring, sow as early as possible, making the surface very fine and smooth, then raking it over and sowing the seed just before a rain, which, if the surface has just been raked, will cover the seed sufficiently. If the expected rain does not come, cover by rolling with a light roller. If sown in the fall, sow before the autumn rains have ceased, and before very cold weather. Give the young grass a light dressing of manure. One pound of this mixture is sufficient to sow a space $30 \times 20$ feet, or 600 square feet. Kentucky Blue Grass in conjunction with White Clover forms one of the finest and closest of lawns. For this purpose use four bushels of Blue Grass and about six pounds of White Clover per acre. Lb., 25c.; by mail, 30c.

Orchard Grass, or Cock's Foot.-One of the most valuable grasses on account of its quick growth and valuable aftermath. It is ready for grazing in spring two weeks sooner than most grasses, and when fed off is again ready for grazing in a week, and will continue green when other grasses are withered by dry weather. It is palatable and nutritious, and stock eat it greedily when green. It has a tendency to grow in tufts and so does better when sown with clovers, and as it ripens at the same time, the mixed hay is of the best quality. For grazing it has no equal, and should be used more than it is. When sown alone, two bushels are required per acre; if sown with clover, half that amount. It is perennial and will last for years, but its habit of growth unfits it for lawns. $14 \mathrm{lbs}$. per bushel. Lb., 20c.; by mail, 25c.

Timothy.-Forty-eight pounds to the bushel. This is a field and not a pasture grass, as it will not endure close and fre- 
quent cropping, but for a hay crop on strong soils, it will produce more than any other sort. Not so well suited for light sandy soils; most valuable of all grasses for hay, especially at the North. Onefourth to one-half bushels per acre. Lb., $10 \therefore$; by mail, $15 \mathrm{c}$.

Japanese Millet.-A new variety recently introduced from Japan, greatly surpassing the ordinary variety of Millet and Hungarian grass in vigor of stalk, yield of seed and value of crop. From reports received those who have grown it the past season are loud in its praise. The plant attains an average height of six feet, short jointed, and at every joint there is put forth an immense number of long, thick, fleshy leaves that increase its value as a cattle food. The seed constitutes an excellent food for hens, and is considered equal in value to corn meal for milk production. The stalks are very juicy, making excellent green food, and should prove valuable when cured as silage. When cured as hay, chopped, moistened and sprinkled with meal, it is readily eaten by cattle and horses. Sow in drills 15 inches apart, with 12 to 15 lbs. per acre. It shculd be generally tried this season. Lb., 10c.; by mail, $15 \mathrm{c}$.

German IMillet.-Requires a dry, light rich soil, and grows two and one-half to four feet high, with a fine bulk of stalks and leaves, and is excellent for forage. For hay, sow broadcast, one-half bushel per acre, from May 1 to August 1. For grain, sow in drills, one peck to the acre and not later than June 20. Lb., 10c.; by mail, $15 \mathrm{c}$.

Hog Millet.-This millet has been known in some localities for years, and ustrally under the name of Froon Corn Millet. The name by which we designate it, Hog Millet, has been applied to emphasize the use to which it is now largely put as an economical and highly valuable food for stock, especially hogs. Per 1b., 10c.; by mail, 15 c.; per bushel, $\$ 2$.

Canadian Blue Grass (Poa Compressa) -Somewhat like Kentucky and as price is lower may be used as a substitute. The hayr, although short, is very heavy and rich. Lb., 20c.; by mail, $25 \mathrm{c}$.

Hungarian Grass.-This is a species of millet, growing less rank, with smaller stalks, often yielding two or three tons of hay per acre. It is very popular and valuable with those who are clearing timber lands. Like the millet, it is an annual and requires to be sown every season, but will produce a larger return than almost any other crop. Sow and cultivate like millet. Ficrty-eight lbs. per bushel. Lb., 10c.; by mail, $15 \mathrm{c}$.

Brome Grass (Bromus Inermus).Native grown. The great forage grass of Rt:ssia. This grass is certainly the greatejt boon ever discovered. Not only is it the grass for dry sections, but it can be raised on almost all kinds of soil and in any climate. It being a native of Russia makes it particularly desirable for our Northwest.

Description. - It originated in Russia, and is recommended on account of the manner in which it has stood on the. Hungary Plains, where the dry, sterile nature of the country and the long continued drouths make so many plants succumb. This Bromus, however, stands well, and has been known for thirty years to stand when such robust crops as Lucerne have been destroyed. It gives a luxuriant crop. It is found that animals eat it greedily, whether in the green or in the dry state, so that it can be used as nown or saved for winter use. Lb., 20c.; postpaid, 25c.

Western Rye Grass.-The seed of this grass is grown and found in our own western country. It makes splendid hay and pasture; it gets green very early in spring and keeps green late in the fall. Lb., 10c.; by mail, 15c.

Spring Vetches, or Tares.-A species of the pea, grown extensively in England, a. 1 to a considerable extent in Canada, for stock, but not much used in the States. Culture, same as field peas. Two bushels per acre. Lb., 7c.; by mail, 12c.

Buckwheat, Japanese.-It is rare that a new grain is introduced which has so decided and evident merit as this. The plarts are very large and vigorous, making a big stand when other sorts failed entire$1 y$. It matures its seed early, and the grain is much larger, and at the same time has a thinner hull than the Common oi Silver hull. We can recommend this as a great acquisition. Lb., 5c.; by mail, $10 \mathrm{c}$.

Rye, Spring.-Although this grain is often planted by farmers, especially for the paper-makers, who prefer it to any other, its principal value is as a "catch" crop, to sow where winter grain has failed. The straw is shorter and stiffer than that of the winter variety, and is always easily secured, while the grain, although smaller, is of equal value. Lb., 5c.; by mail, $10 \mathrm{c}$.

Field Peas.-The kinds mostly used are Golden Vine. Crown, Mummy, White Field Peas, Marrowfat Black Eyed, Mar- 
rcwfat White Eyed. Prussian Blue. About three bushels per acre.

\section{I,b. Mail. Pk. Bush.}

Black-Eyed Marrowfat. ..jc 14c 50c $\$ 2.30$ Vhite-Eyed Marrowfat ..5c 10c 50c 2.30 Golden Vine.......... . . $10 \mathrm{c} 40 \mathrm{c} 1.80$ Crown............... . Field Peas, White......5c 10c 40c 1.65 Prussian Blue........ . 5̌c. 10 c 60 c 2.00

\section{Corn, Ensilage.}

North Dakota Flint.-We are glad to state that this fodder corn has no equal. It is a rapid grower, with a great abundance of leaves; wonderfully tender stalks, and gives by far the greatest yield per acre. Every farmer and dairyman knows tine value of a good crop of fodder corn for feeding cattle during the winter months. This corn has been carefully tested, and found that it gives almost double the nourishment of common varieties. This is the corn that Mr. Bedford claims beats all others at the Experimental Farm, Brandon. Lb., 5c.; by mail, 10c; 1 bush., $\$ 1.50$; 2 bush., $\$ 2.90$; 5 bush., $\$ 1.25$. Seamless bags, 20c. extra.

Notice to Buyers of N.D. Flint Corn. -Please send in your orders for the $a b$ ve, so as to be sure of getting it at the right time. Last year it was difficult to get a surplus later on in the season. Orders filled in rotation. When ordering, plése state whether you prefer the White or Yellow.

\section{Field Corn.}

Large Yellow Dent.-Of a bright yellow color; the ears are large and of fine shape. Lb., úc.; by mail, 10c.; per bush., $\$ 1.70$.

Large White Dent.-Very similar to the preceding variety, except in color, which is white instead of yellow. Lb., 5c; by mail, 10c.; per bush., $\$ 1.70$.

Ensilage Red Cob.-Many people think thai any kind of corn will do for ensilage or fodder. This is only partially true. Some varieties are much better for this puprose, giving a larger proportion and better quality of fodder. What we offer is especially valuable, and will give an imnense yield of fodder of the best quality. Lb., 5c.; by mail, 10 c.; per bush, $\$ 1.50$. Seamless bags, 20c. each.

Mrs. Daniel Leitch, Mountain Gap, Ma1i.,writes: I think your Seeds are good, everything came up. Be sure and send me the garden book.

\section{Speltz.}

What is it? It is neither corn, nor wheat, nor rye, nor barley. It is a combination of these, so to say. It is more like wheat than any of the others menticled, but it is one of the greatest fodder priducers in the wide, wide world. It is fed without threshing; no, not that, but it is fed with the hull, and in this way it yields all the way from 40 to 80 bushels pur acre. It does unusually well in Manitobii It will bear a trial anywhere. Sow 1 bushel per acre, and you will be surprised and delighted at its yield and at its fetding quality. The straw is exactly like wheat straw. Pkt., 5c.; 1 1b., 20c.; 3 lbs., $50 \mathrm{c}$, post paid, by freight or express, at purchaser's expense. Peck, 65c.; ' bush. of 50 lbs., $\$ 2.25$. Bags free.

\section{Rape.}

This plant is extensively cultivated in Engiand, both for forage and tor the seed, from which is manufactured rape seec: oil. The seeds are also much used as fcod for canary birds. It is often used as a salad plant, like mustard. As a foraje plant, the yield is abundant, and fed green it is very nutritious, and nearly all animals are very fond of it. Sow in May, either broadcast or in drills; if the former, 10 lbs., and. if the latter, four lbs. per acre. Lb., 10c.; by mail, $15 \mathrm{c}$.

\section{Wild Rice.}

Directions for Sowing.-Put the rice in in water for 24 hours. Sow in water which is from 5 inches to 6 feet deep, in soft mud bottom, and in places where there are but few weeds. It is useless sow ing this seed except on a mud bottom, or: in low marshy places which are covered with water the year' round. In running wate1 sow as much out of the current as pcssible. A native of our northern district. Valuable as a forage plant for swomps and inundated lands. Stock of ail descriptions are fond of it when green, ant also when cured for fodder. Lb., $40 \mathrm{c}$; by mail, 45c.; 20 lbs. seed per acre.

Mr. M. W. Heathcote, Edmonton, writes: "It may interest you to know that upon an expenditure of 55 cents on Red Wethersfield, Yellow Danvers and Prize Taker Onion Seeds, my wife has sold up to date $\$ 22.15$ worth and has still several buthels left, while she has used large quantities. 'We use PERKINS' SEEDS. 


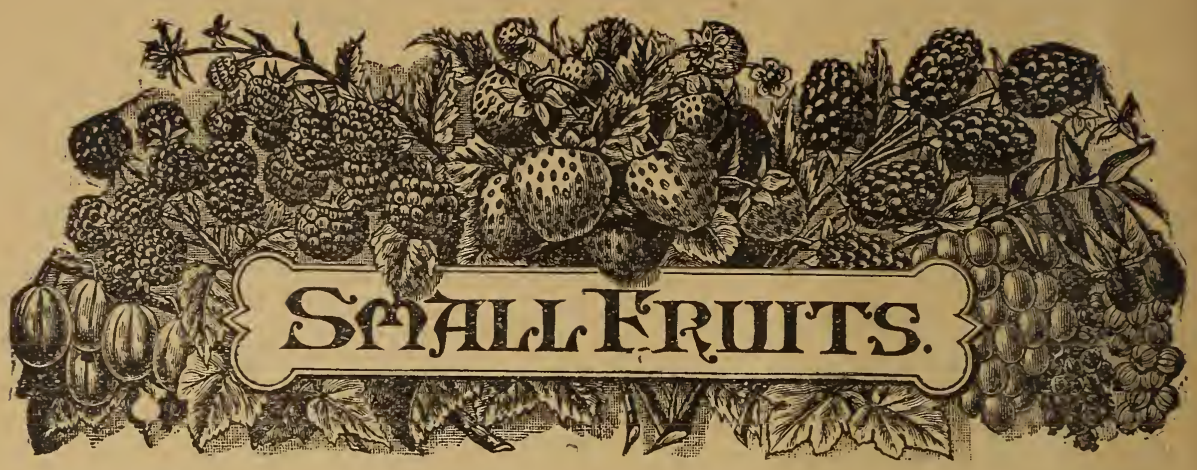

Raspberry.

Cuthbert, Red. - The leading market variety; proved of such general adaptability. Canes hardy and strong, rampant growth, with large, healthy foliage, and exceedingly productive. Berries large, dark crimson, quite firm and of good flavor. Price per dozen, 40c.; per dozen, by mail or express, prepaid, $75 \mathrm{c}$; per 100 , \$2; buyer pays charges.

Turner.-Per doz., 40c.; per 100, $\$ 2$.

\section{Strawberry Plants.}

Crescent Seedling. - James Vick. The two best for this climate; perfect flowers. Doz., 35c.; 100, $\$ 1.50$.

\section{Currant.}

Fay's Red Prolific.-One year old, $\$ 1.50$ per doz.

Large Red Cherry.-The most popular market sort, and uniformly the largest of all red currants, except Fay's Prolific. Bunches large, berries very large, bright, sparkling, crimson, beautiful, very acid. Per doz., 75c.; per dozen by mail or express, prepaid, $\$ 1$. Two years old, per doz., $\$ 1.25$; per $100, \$ 4.50$; buyer pays charges.

White Grape.-The largest and decidedly the best WHITE variety, and one of the best of any for the home garden. Blinch large and long; berry large, handsome, translucent white, and of best quality, being less acid than others. Per doz., $75 \mathrm{c}$; ; by mail or express, $\$ 1$. Two years, per doz., $\$ 1.25$; per $100, \$ 4.50$; buyer pays charges.

Black Champion. - New, the finest Elack Currant, large as Lee's Prolific, much more delicious, and a great cropper on soils which do not suit other varieties at all. Each, 15c.; per doz., $\$ 1.50$; by mail or express, prepaid, $\$ 1.80$.

Black Naples.-A fine, BLACK currant and a great favorite. Per doz., $75 \mathrm{c}$; b. mail or express, prepaid, \$1. Two years old, per doz., $\$ 1.25$; per $100, \$ 4.50$; buyer pays charges.

\section{Gooseberry.}

Houghton. - Vigorous and a good yie!der. Fruit red, sweet and handsome. Prices, $15 \mathrm{c}$. each; five for $50 \mathrm{c}$.; twelve for $\$ 1$. Per doz., by mail or express, $\$ 1.25$.

\section{Rhubarb Roots.}

Best Victoria_Best Linneaus-Large and Early.— $\$ 1.50$ per doz.; freight paid by purchaser.

A.sparagus Roots.-One year old. By mail, prepaid, $\$ 1.50$ per 100 .

All of the above are grown by one of our most successful market gardeners near Winnipeg; therefore, we claim they are acclimatized, and consequently better than imported stock.

Mr. William Davis, Mount Pleasant Farm, Yorkton, Assa., writes: "Herewith I enclose order for Seeds. What I had last year gave very great satisfaction. I think EVERY seed must have grown. While you can supply me with Seeds as good I shall continue a customer."

Mrs. M. A. Lee, "Wolverine," Harrowby P.O., Man., writes: "The Seeds I got last year from you were most satisfactory; the pansy bed was lovely, the marrow was the only true English marrow I have got here. Please send same again." 


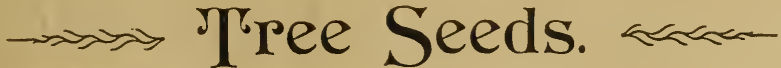

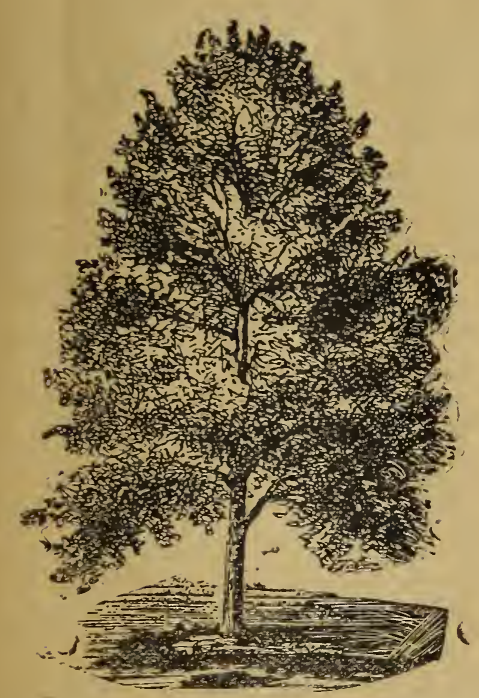

Manitoba Grown Ash Leaf Maple.

Box Elder (Acer Negundo).-Out on our wide prairie we all feel the absence of trees. In order to give everyone an opportunity to beautify their homes at a trifling expense, we secured last year a large quantity of Manitoba Ash Leaf Seed, which we can thoroughly recommend, and by sowing some of which every one can in a few years largely increase the value of their homestead, by having it enriched by a fine belt of timber. TRY IT. Pkt., 5c.; per oz., 10c.; per 1b., 60c.; by mail, 65c. Soak seeds 5 or 6 days before planting.

Evergreen Tree Seed.-The seed of the evergreen trees should be kept in a dry, cool place until time of sowing. As early in spring as the ground can be worked the seeds should be sown thinly in beds of fine sandy loam, raised about four inches above the general surface. The seed can be raked in, or if very small it may lay upon the surface, and then be rolled in or patted with the back of the spade to firm the earth around the seed. Then water very sparingly and with a fine spray. The young plants are very apt to damp off, and need to be shaded from the hot sun and drying winds. A good shade can be made of laths nailed two inches apart to a light frame. This should be supported about eight inches above the seed bed in such a way as to be easily removed to allow cultivation and weeding. Do not allow the young plants to become choked with weeds. Let them remain one or two years before transplanting to permanent ground.

American Arbor Vitae (Thuja Occidentalis).-Seldom over thirty feet high. Grows well under cultivation, and makes one of the best hedges for a screen and a wind-break. It is best grown from seed, which should be sown and the trees transplanted as directed above. About 20,000 seedis per ounce. Pkt., 5c.; oz., 25c.; $\frac{1}{4}$ lb., $75 \mathrm{c}$. ; lb., $\$ 2.25$.

Hemlock (Tusuga Canadensis).-One of the most beautiful of our native evergreen trees. Of graceful habit, with graceful and delicate foliage. The bark is used very extensively for tanning. It requires a light dry soil. About 12,000 seeds per onnce. Pkt., 5c.; oz., 40c.; $\frac{1}{4}$ lb., $\$ 1.25$; 1b., $\$ 6.00$.

Scotch Pine (Pinus Sylvestris).--Very hardy; grows surely and rapidly on nearly every variety of soil, forming a beautiful tree. Valuable for a windbreak. About 4,800 seeds per ounce. Pkt., 5c.; oz., 20c.; $\frac{1}{4}$ lb., 60c.; 1b., $\$ 1.75$.

Norway Spruce (Abies Excelsea).Well-known as one of our most beautiful evergreen trees. It is hardy, of rapid growth, and forms a dense close screen or hedige. About 20,000 seeds to the pound. Pkt., 5c.; oz., 15c.; $\frac{1}{4}$ lb., 40c.; 1b., $\$ 1.50$.

Russian IMulberry.-Of rapid growth, resembling the apple tree in habit, with a grcyish bark and drooping branches. It is very easily cultivated and kept in dwarf form, makes a fine hedge and windbreak. It bears very young, and the fruit is similar to the blackberry, varying in flavor from sub-acid to sweet. In cold regions especially this should prove a very valuabie variety for its timber, shade and fruit. About 20,000 seeds per ounce. Pkt., 5c.; 07., 20c.; $\frac{1}{4}$ lb., 60c.; 1b., $\$ 2$.

Barberry (Berberis Vulgaris).-One of the best hedge plants grown. It is very hardy and forms a dense shrub of from four to eight feet high, covered with sharp, stout prickles. Pkt., 5c.; oz., 20c.; $\frac{1}{4}$ lb., 50c.; 1b., $\$ 1.50$.

Honey Locust (Gleditschia).-A wellknown tree, of ornamental and graceful appearance, extensively used for hedges. Pkt., 5c.; oz., 10c.; 1b., 50c. 
Siberian Pea.-Well known as one of our most beautiful and ornamental hedge plants, of vigorous growth, very hardy and well adapted to our climate. Soak sceds 12 hours before planting. Pkt., 5c.; oz., 20c.; 1b., \$1.25.

Beech (Fagus Ferrurinea).-A noble forest and shade tree of graceful habit. Wood hard and excellent for many mechanical purposes. Pkt., 10c.; Oz., 15c.; $1 \mathrm{~b}, \$ 1.00$.

Catalpa, Hardy Western (Catalpa Sieciosa).-A handsome shade and ornamental tree, of tropical appearance. Foliaze large and luxuriant. Flowers borne in large panicles late in the spring. In farcrable localities it attains a height of 60) feet or more. It is a very rapid grower, is very hardy and has been tested up to 40 degrees north latitude. Wood very durable. A valuable tree. Pkt., 10c.; oz., 35 c. ; $\frac{1}{4}$ 1b., $\$ 1.00 ; 1$ lb., $\$ 4.00$.

Hawthorn.-Pkt., 5c.; oz., 10c.

Blackthorn (Prunos Spinosa).-Packet, 5c.; oz., 10c.; 1b., \$1.00.

Lilac.-The well-known purple and white, sweet-scented varieties. Pkt., 5c.; oz., 30c.

Sugar Maple (Acer Saccharinum).-A beautiful as well as a valuable rapid growing tree, preferring a calcalous soil. Pkt., 5c.; oz., 10c.; 1b., \$1.25.

Mountain Ash (Pyrus Americana).Much cultivated for ornament, for which its fine foliage, clusters of white flowers and red berries eminently qualify it. Pkt., 5c.; oz., 10c.; 1b., $\$ 1.00$.

Sycamore.-Pkt., 5c.; oz., 10c.
Osage Orange (Maclura Aurantiaca).A well-known hedge plant; native of Southern States. Pkt., 5c.; Oz., 10c.; 1b., $\$ 1.00$.

European Ash (Fraxinus Excelsior).Succeeds best in rather a warm climate. Thrives upon the plains in deep soils, but does poorly upon stiff clay or light sandy soil. Its timber is valuable in carriage making and manufacturing. About 600 seeds per ounce. Plit., 5c.; oz., $15 \mathrm{c}$.

White Birch (Betula Alba).-Valuable for ornamental planting, and a favorite wood for shoe pegs, spools, bobbins and similar small articles. The birch prefers a cool, humid climate, and is readily propagated from seed. The seed thrives best on new ground. It scarcely admits of any covering, but if simply pressed into the ground with the feet will grow. When one year old, transplant into nursery rows. When two or three feet high, set out the young trees where they are to remain. Pkt., 5c.; oz., 15c.

True English Sweet Briar.-Valuable for the refreshing fragrance of its leaves. Sweet scented; very hardy. Fine for making a hedge. Pkt., 5c.; oz., 15c.

Basswood.-Of very rapid growth and very ornamental. Pkt., 5c.; oz., 15c.; per 1b., $\$ 1.50$.

\section{Lilac Trees.}

Either White or Colored.

Size.

Price.

3 feet high ...........40c. each.

2 feet high $\ldots \ldots \ldots \ldots \ldots \ldots$. . . . . 25 c. each.

1 foot high ... . . . . . 15c. each.

If sent by express purchaser pays express charges.
Mr. James Bennett, Belmont P.O., Nian., writes:- "I received the "Iron Age" Hoe Cultivator O.K. I thought I would give it a fair trial before reporting on it. I think it is without exception the best garden tool ever invented. My garden is $65 \times 40$ yards, with twenty-four rows of snall fruit trees. It looked like a howling wilderness, with grass and weeds, before I got the Cultivator. It just took me about six hours to hoe them out. Then I raked them up and got thirty barrowlcads out of it; then I went all over with the Cultivator to loosen the ground up. To-chay I went all over it again with the Hces, and it just took me one hour and a half. I was advised by several people not to get one, as it would be impossible to work it by hand; they would say, "Get a horse cultivator." I am glad I didn't, as I car do better work with the hand one. My boy, nine years oid, can work it. If men that have gardens could only see the Cultivator working, I don't think they would hesitate a moment. You can use my letter, with fifty good-wills. 


\title{
DESCRIPTIVE LIST OF SELECT
}

\section{Ghoice Imported Flower Seeds.}

\section{BRIEF HINTS ON SOWING AND CULTIVATION.}

\author{
Flower Seeds sent Free by Mail on Receipt of Price. In ordering Flower \\ Seeds, it will only be necessary to give the number.
}

1. Abronia.-A charming trailer, with verbena like flowers, in bloom the entire summer Half hardy annual, $5 \mathrm{c}$.

2. Andonis Flower.-Of easy culture. Foliage pretty. Hardy annual; one foot high. Dark blooded red, fine, 5c.

3. Asperula. - A profuse blooming, dwarf, hardy annual, with sweet-scented, delicate lavender blue flowers; beautiful in bouquets. Height, one foot, $5 \mathrm{c}$. form and color. They are all hardy annuals, and are all equally easily grown. The following list is arranged according to height.

8. Snow White ... ........ . . . .

9. Improved German Quilled.. .. 5c.

10. Double Mixed Colors .. .. .. 5c.

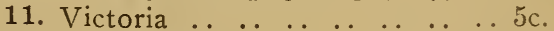

12. China Mixed .. .......... 5c.

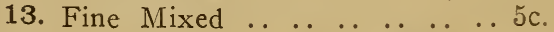
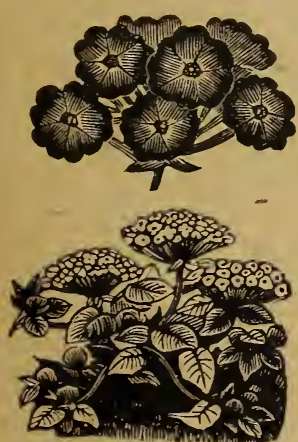

Abromia Umbellata.

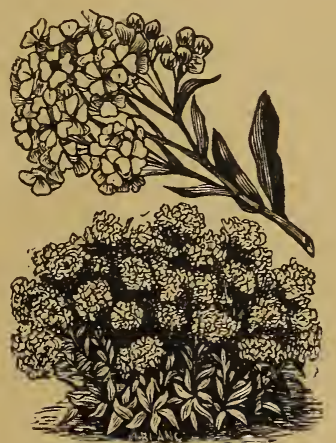

Alyssum.

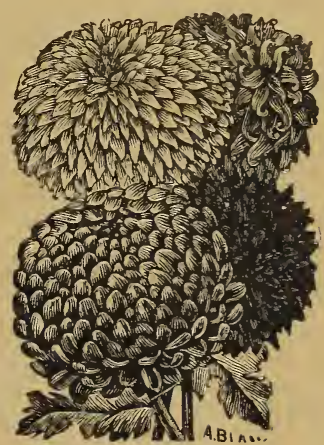

Asters (Quilled).
4. Alyssum (Sweet).-Very pretty for beds, edging or rock work, $5 \mathrm{c}$.

5. Alonsoa (Mask Flower).-Are small, but are of remarkable brilliant color, and make a most desirable bedding plant. They fower freely and continue to bloom from June till early frost. Half hardy annual. Fine mixed, $5 c$.

6. Ageratum.-Mixed blue. .. . . 5c.

7. Agrostemma.-(Coeli Rosa). .. 5c.

Aster.- I hose old, reliable and universal favorites have been so wonderfully improved of late years that now they may be had in almost endless variety and sizes,
14. Bachelor's Button.-Under cultivation this is really a handsome flower, sporting into varieties of white, purple, pink, parti-colored, etc. Hardy annual, two or three feet high, $5 \mathrm{c}$.

15. Ballon Vine.-Rapid climber, 5c.

Balsam (Impatiens).-Also called Lady Slipper and Touch-Me-Not. The Balsam his been so greatly improved by cultivation of late years that with proper treatment and good seed a single flower is the exception now rather than the rule. Hardy annual, one to two feet high.

16. Double Pure White.. .. ... . 5c. 17. Double Camelia, Finest Mixed $5 c$. 


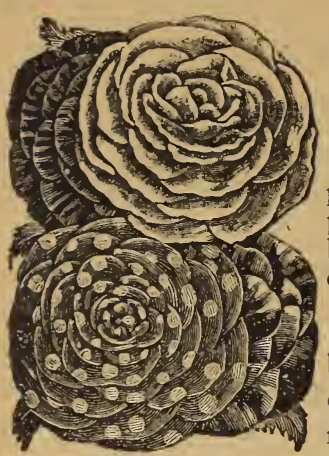

Balsam.

18. Double Salferino, Finest Mixed 5c.

19. All Colors, Mixed .. .. .. ..5 5c.

20. Dwarf Double Mixed .. .. .. 5c.

21. Bartonia.-A very pretty flowering plant of the gentian family, producing a profusion of fine, bright, metallic, yellow blassoms, about two inches across. Tender annual, one foot high, $5 \mathrm{c}$.

22. Calliopsis, or Coreopsis.-A showy border plant, producing flowers in nearly every shade of yellow, orange, crimson, red and brown. Hardy annual; two feet high. Fine mixed, 5c.

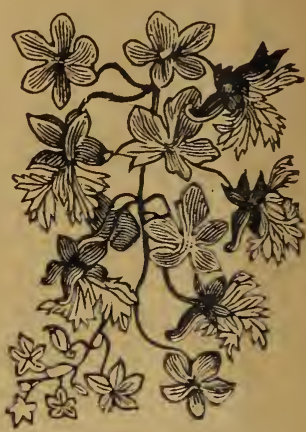

Canary Bird Flower.

23. Canary Bird Flower.-A beautiful clirs:ber. The charming little canary-colored blossoms, bearing a fancied resemblailce to a bird with its wings half expanded. The plant has a fine, luxuriant, rambling character; and if the seeds are planted by the side of an arbor or trellis, to run upon, it will run 20 feet high and blossom. 5c.

24. Canna, or Indian Shot.-Very stately and highly ornamental plants, with large, broad, massive foliage, and rich crimson, scarlet or yellow flowers. When plaited in groups or masses they impart a tropical aspect in the garden. They are half hardy and produce fleshy roots, which if taken up and placed in a cellar, may be divided every spring and used like Dahlias for years. Mixed, 5c.

25. Cacalia (Annual).-A showy plant of easy culture, producing beautiful scarlet and golden-yellow tassel-shaped blossoms from July to October. It is sometimes known as Flora's Paint Brush. Locks best when grown in clusters. Succeeds best in a mixture of fresh loam and leaf mould. Sow early in spring, in open ground, in clusters. Hardy, $1 \frac{1}{2}$ feet. Mixed, $5 \mathrm{c}$.

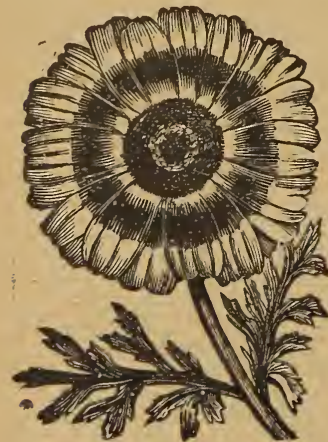

Chi ysanthemum Tricolor high Mixed, $5 \mathrm{c}$. Mixed, 5c.
Candytuft (Iberis).-Universally known and cultivated , and considered indispensable for cutting. All the varieties look best in beds or masses. Hardy annual, 1 foot high.

26. Candytuft, purple .. $\ldots . . .55$.

27. Candytuft, white .. ... ... . 5c.

28. Candytuft, fine mixed .. .. .. 5c.

29. Calendula, Meteor. - A new variety; very fine for pot culture, bearing larce, light yellow flowers, striped with orc̈nge, $5 c$.

30. Cineraria (Hybrida or Flowering Varieties). - Magnificent and indispensable flowering for spring decoration for the conservatory or window garden. The flowers measure two or three inches across, are of white, blue, violet and crimso1: shades, covering the plant with a sheet of bloom. Mixed, 5c.

31. Clarkia.-The flowers are very pretty and of very many colors, double and single. It is better to sow the seed in September, and the plants will be large encugh by spring to make good bloom. Hardy annual, $1 \frac{1}{2}$ feet high. Mixed, double, $5 \mathrm{c}$.

Convolvulus, or Morning Glory.Dwarf plants, of trailing, branching habits, each plant occupying a space of two feet. At mid-day they are completely cover ed with a mass of most brilliant, many colcred blossoms, which remain open till evening. Half-hardy annual, one foot

32. Convolvulus, Minor, or Dwarf.-

33. Convolvulus, Major, or Tall-

34. Coleus. - Beautiful ornamented foliage plants, both for hot house and bedCandytuft. 


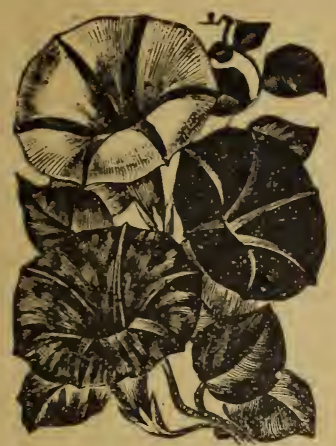

Convolvulus.

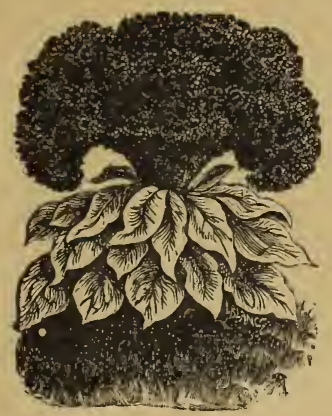

Celosia.

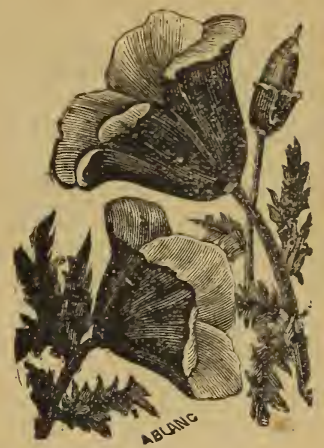

California Poppy. ding out during summer, the broad oblong leaves being of a deep crimson brown color, edged with green, or yellow or salmon color, or mottled in a most pictrresque manner. Finest mixed, $10 \mathrm{c}$.

35. Celosia Cestata (Cockscomb).Glasgow Prize.-This is one of the largest and brightest of the common Cocksccmbs, 5c.

36. Cypress Vine.-A most beautiful cliniber, with delicate dark green, feathery foliage, and an abundance of bright, starshaped, rose, scarlet and white blossoms, which in the bright sunshine present a mass of beauty. Planted by the side of a verandah, tree or stakes, and trained properly, there is nothing prettier. The seed will germinate more freely if warm water be poured on the ground after planting. Tender annual. Fifteen ft. high. Mixed, 5c.

37. Scarlet .. . . . . . . . . . . . . 5c.

38. Catchfly.-A free blooming plant, with dense umbels of pink-like flowers; fire mixed. Height, one foot, $5 \mathrm{c}$.

39. Cowslip.-The well-known favorite English Cowslip, flowering early in the spring. Mixed colors, $5 \mathrm{c}$.
40. Carnation.-Double, mixed. .. 5c.

41. Marguret, double ... ..... 5c.

4.2. Centaurea.-Mixed ...... .. 5c.

43. Canterbury Bell (Calacanthema, mixed.)-One of the newer sorts. Flowers large, of fine form. White, lilac, rose and purple, $5 c$.

44. Crysanthemum. - Tricolored, mixed, double, $5 c$.

45. Dahlia. - Finest double, mixed. Seed saved from choicest double flowers, $5 c$.

46. Dahlia. - Finest single, mixed. Brilliant flowers running through a wide range of striking colors. Easily raised from seed and very desirable, $5 c$.

47. Digitalis (Fox Glove) (Biennial). -Ornamental plants of much beauty, producing dense spikes of flowers of many coors, on stems three to five feet high. Mixed, 5c.

48. Daisy (Bellis). - Charming little plant for edgings and borders. The flowers are quilled and flat petaled, pink, red and variegated. Flowers are most abun-

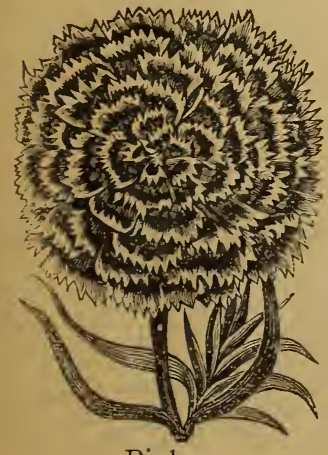

Pink. dant in spring. Tender perennial; six incles high. Pkt., 5c.

49. Double White ... . . . ..10c.

50. Mixed Double.. .. . .. ...10c.

51. Datura (Annual).-A large strong grcwing, hardy annual, which possesses attiactions of the highest order. In grcups or for border of shrubbery they are very attractive. Sometimes called the "Angel's Trumpets." Very large, double flcwers, $5 c$.

52. Everlastings (Double Mixed).-A sir:gle packet will supply a great variety

of attractive everlastings. Pkt., 5c. Carnation (perpetual)

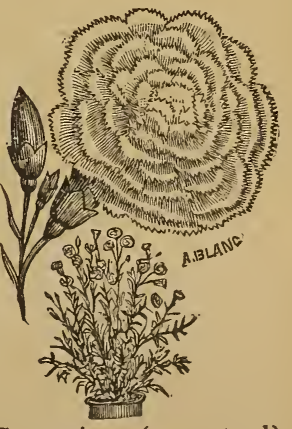




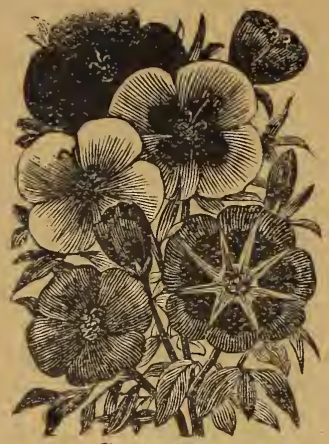

Godetia.

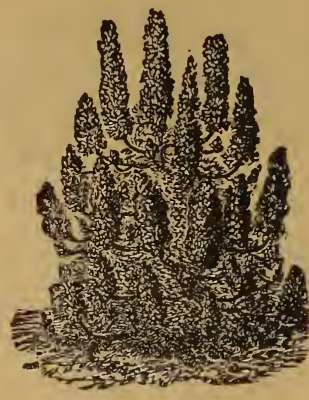

Larkspur.

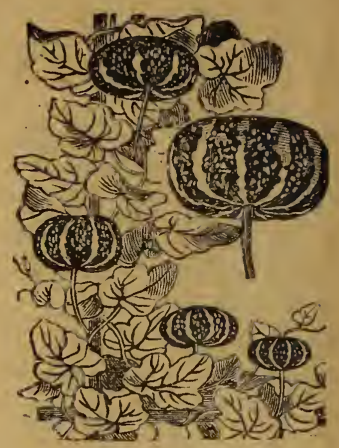

Gourds.
53. Eschscholtzia (California Poppy) (Annual).-Very attractive plants for bəds, edgings or masses. Profuse bloomer, and fine cut foliage, in bloom from June to frost. Height, one foot. Mixed, $5 c$.

54. Forget-Me-Not (Myosotis). - The Fcrget-Me-Not is an old favorite plant, bearing clusters of star-shaped delicate blue flowers with white and yellow eyes. It flourishes best in a moist, shady situation, and it is in constant bloom nearly the whole season. If the seed be sown in autumn it will succeed best, and flower early in spring. Hardy, perennial. Six inches high. Mixed, 5c.

55. White. . . . . . . . . . . . 5c.

56. Blue . . . . . . . . . . . . . 5c.

5\%. Fuchsia.-Best mixture, 5c.

58. Gallardia (Blanket Flower). - Exceedingly showy; produces large flowers of scarlet, white and yellow, borne freely throughout the summer. Height 1 to 2 feet. Mixed, $5 c$.

59. Gilia.-Hardy annual; very free flowering; suitable for sowing in masses. Mixed, $5 c$.

60. Godetia. - (Annual). - Beautiful garden plants, of easy cultivation in any good garden soil, and noted for the delicacy of their fine, large blooms. Finest mixed, 5 c.

61. Geranium.-Fancy mixed, 5c.

Gourds (Cucurbita).-A tribe of climbers, with curiously shaped fruits in various colors, being one of rapid growth, they are fine to cover old fences, trellises, stumps, etc. The foliage is quite ornamental. Tender annual climber. Ten to tweinty feet high.

62. Syphon or Dipper .. . . . . . 5c.
63. Orange and well-known Mock Orange, 5 cents.

64. Japanese Nest Egg, white; fac simile of an egg; do not crack and are not ininred by heat or cold. Very ornamental climbers, $.5 \mathrm{c}$.

65. Mixed, ornamental, 5c.

Larkspur (Delphinium). - The Larksp11 is one of the handsomest and most useful of plants, and for-large gardens it is invaluable. The brilliancy of some of the colors is unsurpassed. 5c.

66. Larkspur, Dwarf Rocket .. .. jc.

Hollyhock.-The Hollyhock in its present state of perfection is very unlike its parent of olden time; it now ranks with the Dahlia, Aster, Camelia, etc. For a background to a flower garden, perhaps no plant is more useful. The flowers are as double as a rose, of many shades of colo1, from deep yellow, red, purple to pure white. Hardy perennial. Five feet high.

67. Double, choice mixed .. ... . 5 5c.

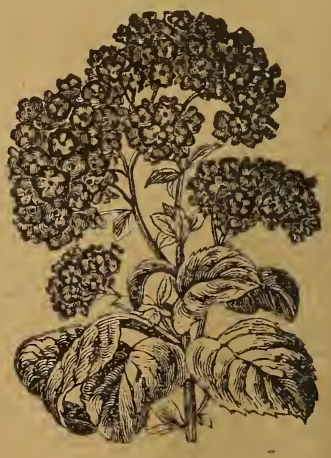

Heliotrope.

68. Heliotrope.-Highly valuable for the fragrance of the flowers and duration 
of bloom. Half-hardy perennial. One fo, $t$ high. Mixed, very choice, $5 \mathrm{c}$.

69. Honeysuckle, French (Hedysarum) - Very handsome, free flowering plants, producing racemes of beautiful pea-like flci ers, particularly adapted for borders or rockwork. Hardy perennial. Four feet liigh. Plit., 5c.

70. Japan Hop.-Pkt., 5̌c.

71. Ice Plant.-A pretty little trailing pla1 l, much used for garnishing. The leaves of which are covered with crystalline globules. Half-hardy annual. Plit., $5 c$.

72. Kenilworth Ivy.-Nice for hanging baskets. 5c.

73. Lavender. - Lavender, a hardy plart, bearing spikes of blue flowers, which are cut and dried for their fragrance. Perennial, from one to two feet hig̣h. Pkt., 5c.

74. Linum (Flowering Flax). - A genus of free flowering, hardy annual or perennial plants. Crimson flowering. Pkt., 5c.

Lobelia. - Plants of widely different styles of growth. Lobelia Erinus varieties are low growing, branching plants, for hanging over vases and baskets. Lobe'in Erinus Compacta make little, round ccmpact plants; fine for edgings, ribbon bed:, etc.

75. Crystal Palace Compacta.-This is the best variety grown for ribbon beds, edgings, etc.; color, a deep blue, 5c.

76. White Gem.-The best dwarf white.

77. Mixed, ǰc.

78. Love Lies Bleeding.-Long, drooping sprays of flowers, $5 \mathrm{c}$.
79. Lantana.-Hybrida mixed. A rapid growing indoor shrub, for bedding during summer, 3 feet; flowers in heads of yellow, pink, orange or changeable colcrs. Pkt., 5c.

80. Lily of the Valley (Canvallaria Majalis).-Lovely spring-blooming plants, bearing pure white fragrant, bell-shaped flcir ers. $10 \mathrm{c}$.

ITarigold.-The Marigold has been an inlabitant of the flower garden from time inmmemorial, and where a rich display of blcom is desired, is almost indispensable. Hardy annual, in bloom till frost comes.

81. Marigold, African.-Mixed, selected from the finest double flowers, very beantiful. $5 \mathrm{c}$.

82. Marigold, French, New Gold Striped.-Magnificent stripes of brown on deep gold, very double, 5c.

83. Musk Plant.-This fragrant and universally favorite little plant is wellkncwn and is equally at home in sittingroon green-house or garden; half-hardy pei ennial. Pkt., 5c.

84. Mimulus (Monkey Flower).-Extremely handsome, dwarf growing, halfhatdy biennials, with delicate, large beautif lly tinted flowers, requiring shelter froul the mid-day sun to bring them to perfection. Spotted, marked, dotted and blotched flowers on yellow ground. Mixed, $5 \mathrm{c}$.

85. Mimulus.-Spotted. 5c.

86. Moon Flower (Grandiflora Hybrida, "The Moon Flower, or Evening Glory").-One of the grandest summer clinibers grown, bearing immense pure white fragrant flowers in great profusion, opering in the evening and remaining

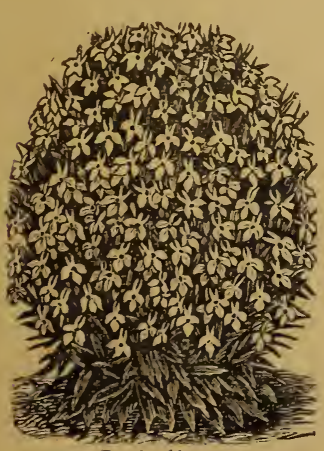

Lobelia.

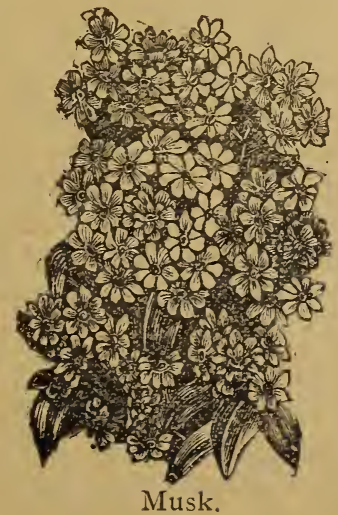

Musk.

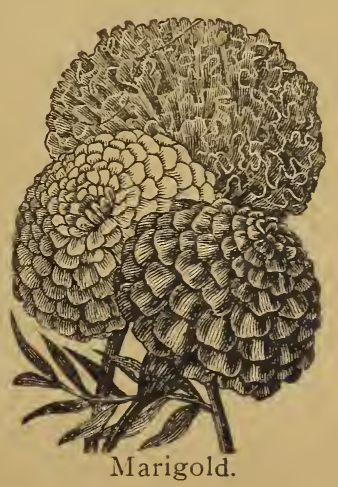

Marigold. 


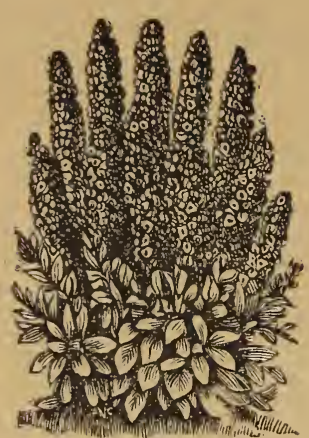

Mignonette.

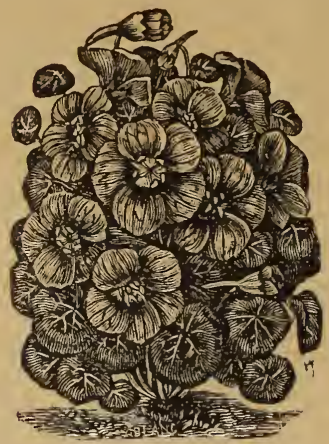

Nasturtium.

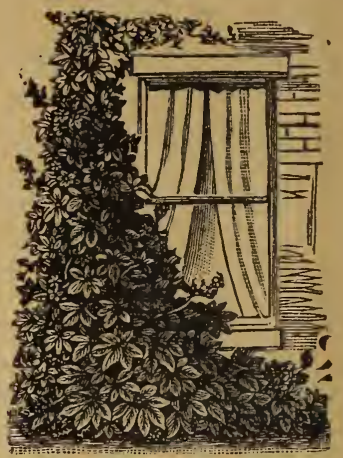

Moon Flower. open until noon the following day, and, if cloudy, all day. Foliage and flowers vary in form and different plants, some ficwers being scalloped, others perfectly roind, others star-shaped; the foliage also varies from the original shape to oak leared and heart-shaped forms, thus addins charm and interest to this grand climber. White seeded, $5 c$.

87. Black seeded, $5 \mathrm{c}$.

Nasturtium, Dwarf (Tropælum Minor).-A bed of Dwarf Nasturtiums in the yard is very brilliant and attractive, and blcoms all the season. Hardy annual. One foot high.

88 Dwarf, King Theodore - Very dark, 5c.

89. Dwarf, Golden King of Tom Thumbs.-Brilliant gold color, $5 \mathrm{c}$.

90. Dwarf, Mixed. $-5 \mathrm{c}$.

Nasturtium, Tall (Tropæolum Lobianum) differs materially from the common running Nasturtium, and is admirat.ly adapted for the green house or conservatory decoration in winter. Colors briiliant and of many shades, from scarlet to black. Fine for covering arbors, trellises and rustic work. Hardy annual; ten to twelve feet high.

91. Tall, mixed; the best varieties, $5 \mathrm{c}$.

92. Nicotiana (Tobacco plants-Affinis).-Of all the varieties of tobacco which are grown for their sweet scented flowers, this is the best. The plant is literally covered with large, white, star-shaped flowers, which, after being cut, will remain perfect for a week. $5 \mathrm{c}$.

93. Nigella (Love in a Mist)-Of easy growth; serrated foliage, with curious looking flowers. Height, one foot. Mixed, $5 c$.
94. Nolana.-Nolanas are of a trailing habit, and admirably adapted for rockwork, hanging baskets, vases, etc. The flowers resemble the morning glory, brilliant, freely produced of various colors. Hardy annuals. Mixed colors, 5c.

Mignonette.-A well-known hardy, annual, producing dense, semi-globular heads of exceedingly fragrant flowers, borne on spikes from three to six inches long. In bloom nearly the whole season, and is so fragrant that the whole atmosphere around is perfumed. No garden should be without it. If sown at intervals during the spring and early summer, it will be in bloom until killed by the frost. Seeds sown in autumn will bloom early in spring. Hardy annual, perennial if protected. One foot high.

95. Matchet.-This extremely fine variety is undoubtedly the best Mignonette yet sent out. Vigorous, dwarf, pyramidical plants, very stout flower stalks, with numerous dark green leaves, terminating in long spikes of deliciously-scented red flowers. Best for pot culture and valuable for borders. Pkt. 5c.

96. Giant pyramids, 5 ct.

97. Crimson Queen, 5c.

98. Sweet-scented. Pkt. 5C. ; $\frac{1}{2}$ Oz., I5C; oz., 30c.

cG. Oxalis.-Delicate, half-hardy annual and perennial. Low growing plants, with leaves like a shamrock. Mixed, nine inches high; rosy flowers; annual; per packet, $5 \mathrm{c}$.

Madam J. Kruppa, Kaposvar P.O., Assa., writes: I send you four orders this year instead of one, and I hope you will sen.t as good Seeds as last year; they were well satisfied with the Seeds and also the onion sets. 


\section{Pansies.}

These lovely flowers are favorites with all, not only for the brilliancy and variety of their colors, but for the durability of their bloom.

100. Bugnot.-The finest strain of Pansie: in existence. The flowers are of enormous size, perfectly round, of great substance and of the most varied and attractive mixed colors. Pkt., 10c.

101. Imported Snow Queen.-Pure wh:te, very popular with growers of the Pai sy. Pkt., 10c.

102. Perkins' Non Plus Ultra.-A strain of Pansy, which for variety and beaty has never been excelled. Of matchless forms, colors and markings, with flowers half as large again as ordinary Pansies. They will both astonish and delight Pansy fanciers. Pkt., 10c.

103. Odier, Cassier and Bugnot.-A stiain of Pansy, which, for variety and beauty has never been excelled. Of matchles:s forms, colors and markings, with flowers half as large again as ordinary Parsies; we are sure that we are offering something that will both astonish and delight Pansy fanciers. Pkt., 10c. varieties, blotched, veined, $\mathrm{m}$ a $\mathrm{rb}$ le d and margined. Our own bed of Pansies, grown in our own garden from this mixture, was acknowledged by the hundreds thit viewed it, to be the best bed of pansies ever grown in Winnipeg. Pkt., 10c.

The above collection of pansies was impcrted direct from one of the largest growers in Germany. We have no hesitation in saying that this is the best collect:on ever introduced in this country. We will send postpaid the above collection of seven for 60 cts., or either three of your own choice for $25 \mathrm{c}$. TRY THESE.

107. King of Black-Coal black, 5c.

108. Pure Yellow, 5c.

109. English Finest Quilled Mixed, 5c.

110. Red Shapes, Mixed, 5c.

111. German, Fin'e Mixed, 5c.

112. Sweet Scented, 10c.

113. Fire Dragon, $5 c$.

Mrs. Wesley Shaver, "The Maples," Minnedosa, Man., writes: I send you my order once more. I think this makes the eighth year I have given you an order, and have always had excellent succes:; with your Seeds. Thanking you for extras.
104. Perkins' Royal Mixture.This is a mixture of our own. It contains all the leading strains as well as the finest named varieties, and will produce a bed of Pansies, which, for size, coloring and freedom of bloom, will be the admiration of all who see it. Pkt., 10c.

105. Butterfiy and Peacock.The lovely ultramarine blue contained in the upper petals most nearly resembles this color in the feathers of a peacock. The name is further justified by the beautiful, almost irridescent blending of colors. Pkt., 10c.

106. The Imperial German Pansies are famous for their almost endless variety of charming shades of color, united with large size and perfect form of flowers. They embrace all the solid or self-colors; delicately shaded flowers; five-spotted and three-spotted; edged or bordered flowers of various colors, each with a distinct rim of white, yellow or blue; dark and light marbled varities; flowers with clear, distinct eyes; striped flowers of striking beauty and vividly colored fancy

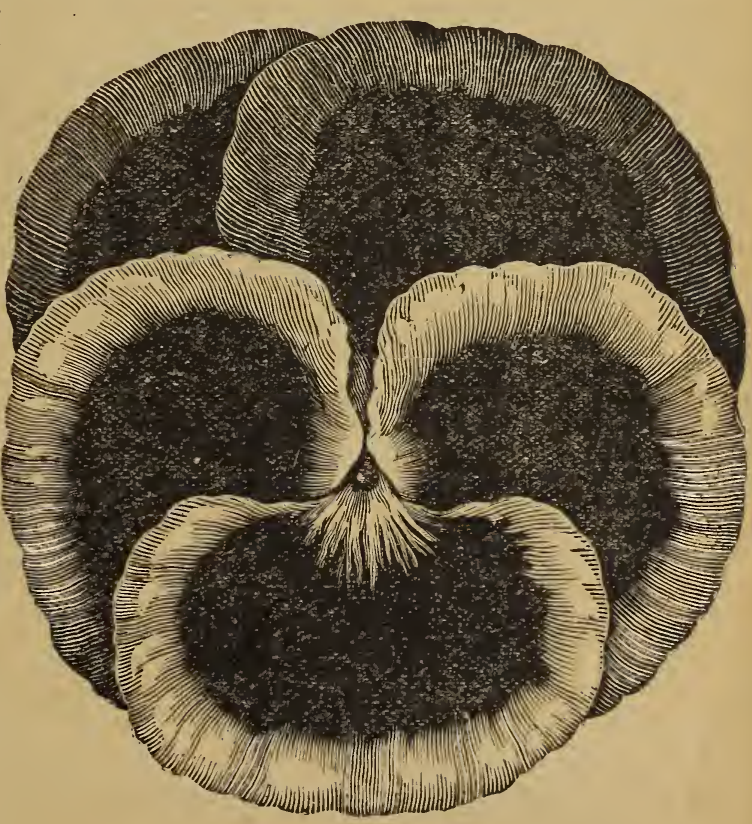

Pansy. 


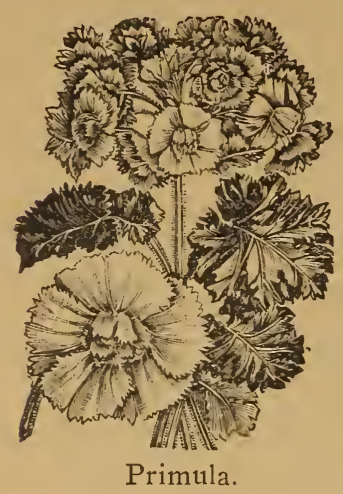

Petunia.-Petunias are unsurpassed for massing in beds. Their richness of color, duration of bloom, and easy culture, will always render them popular. They do well sown in open border in spring or earlier, in cold frame or hot bed, and transplanted 18 inches apart. Tender perennial, but will bloom the first season. One and a half feet high.

114. White, 5c.

115. Fine, Mixed, 5c.

116. Double, Mixed, 10c.

Phlox.-Very hardy annual, thriving almost in any situation, and unequalled in the display of their many and brilliantly coicred flowers. Seed sown in open ground in fall or early spring will begin flcwering July 1st and remain literally covered with blossoms until after the severe frosts late in autumn. For masses of separate colors, or for cutting for bouquet, they are unsurpassed. $1 \mathrm{ft}$. high.

117. Drummondi Grandiflora Alba.Pure white. Comes absolutely true from seed: is of perfect form and color. 5 c.

118. Drummondi Grandiflora, mixed, $5 \mathrm{c}$.

119. Star of Quedlinburg, 10c.

120. Double, mixed, 5c.

Pink (Dianthus).-The family of Dianth:is is by far the most useful of all the biennials and perennials, and for beauty and variety cannot be surpassed. The delicacy and richness of the tints, combired with the aromatic fragrance of many of the species, are valuable recommendations for the entire family.

121. Dianthus, Chinensis, fl. pl. (Doub!e China Pink).-This species is a biennial of dwarf habit; flowers the first year, but the bloom is stronger the seconc. The colors are very rich, and in large beds you can hardly find two alike.

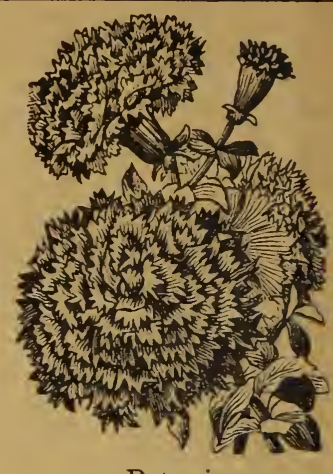

Petunia.

Seeds saved from double flowers will produce double ones. jc.

122. Dianthus, Eastern Queen, 5c.

123. Dianthus, Choice Mixed, 5c.

124. English, Best Mixed, 5c.

125. Pyrethrum (Feverfew) - (Perennial)-A plant of easy culture, and, in fact, one of the best in cultivation. Height six inches. Bright yellow flowers. Pkt. 5c.

126. Primula . (Primrose).-The Chinese Primrose is the great winter blooming favorite. For inside culture we know of no plant that is more attractive or gives more satisfaction. The foliage is very beautiful and the flowers are perfect gems of beauty. Primulas are amongst the finest plants for pot culture. $5 \mathrm{c}$.

Poppy (Annual).-A showy and easily cultivated hardy annual, with large, brilliant colored flowers, growing freely in a ty garden soil, and producing a fine effect in large clumps or mixed beds.

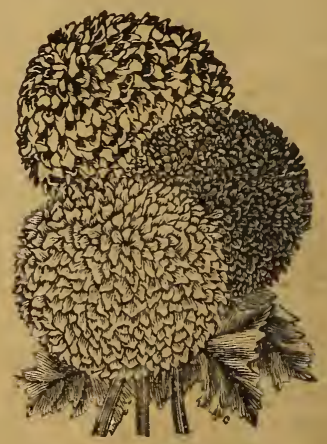

Poppy.

127. Iceland (Papavar nudicaule). These beautiful perennial Poppies produce flowers in great abundance the first year frow seed. The colors range from the 
purest while and yellow to the deepest glcwing orange scarlet, and have a delicious fragrance. Mixed colors. Pkt., 5c.

128. Snowdrift.-This charming new Poppy produces pure, snowy white, extremely double flowers of perfect form and large size. The habit of growth is very neat and compact, and we have in this variety a most valuable acquisition. Height, six feet. Pkt., 5c.

129. Japanese.-The most charming Poppies. Produce very small, but double flowers in great profusion, are exceedingly showy and present a wide range of gay colors. Pkt., $5 \mathrm{c}$.

130. Double Carnation.-Fine Mixed. Pkt., $5 \mathrm{c}$.

131. New Shirley Poppies.-This new and beautiful variety is a grand acquisition to the papaver family, ranging in color from pure white through the most delicate shade of pink, rose and crimson to deepest crimson. They are so varied that no two can be found exactly alike. Pkt., 5c.

Portulaca.-There are scarcely any nowers in cultivation that make such a dazzling display of beauty as a bed of many-hued, brilliant colored Portulacas. They are in bloom from about the first of July till killed by frost in autumn. Tender annual. Nine inches high.

132. Single White. Pkt., 10c.

133. Fine Mixed. Pkt., 5c.

134. Double Mixed. Pkt., 5c.

135. Salpiglossis._-Large flowered hybrids. Extra fine mixed, purple. scarlet, crimson, yellow and blue. Pkt., 5c.

136. Salvia.-One of our handsomest summer and autumn flowering plants, growing into compact bushes about three feot high, and literally ablaze with bril- liant flowers. Very effective for massing on the lawn and for garden decorations. Perennial, but bloom first season from seed. Plit., 5c.

137. Scabiosa (Morning Bride).-One of the handsomest summer plants, with beatitiful variegated flowers, and valuable for bouquets, etc. Also a nice border plant. Mixed colors, dwarf. 5c

138. Tall Mixed, 5c.

Stock.-The Stock as now grown is indispensable where a fine display of flowers is wanted. To such perfection has selecti in brought them that good seed will give a large proportion of flowers as double and large as the named sorts grown from cuttings.

139. Stock, Snowflake.-The earliest White Ten Weeks Stocks. Flowers extramely double and snow white; foliage haridsome. $10 \mathrm{c}$.

140. Cut and Come Again.-10c.

141. Double German, Ten Weeks.Mixed, fine, $10 \mathrm{c}$.

142. Large Flowering.-Ten weeks, white, $10 \mathrm{c}$.

143. Dwarf German.-Ten weeks, fine mixed, $5 c$.

144. Castor Oil Bean.-Large, luxuriant, rapid growing foliage, annuals, with palm-like leaves; much used for sub-tropical effect on the lawn, or for centres of beds of foliage plants. Fine mixed, 5c.

\section{TO OUR PATRONS.}

We would respectfully draw your attention to the announcements of the several advertisers, who are among the leading business houses of Winnipeg, and who will, no doubt, give entire satisfaction to any who may deal with them. Give them a Trial Order.

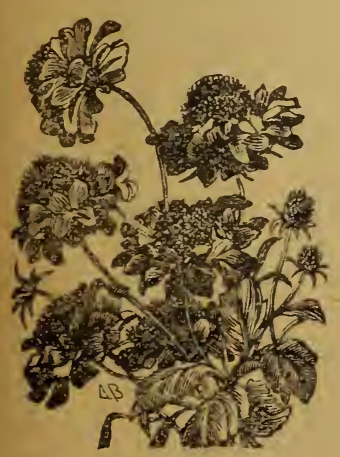

Scabiosa.

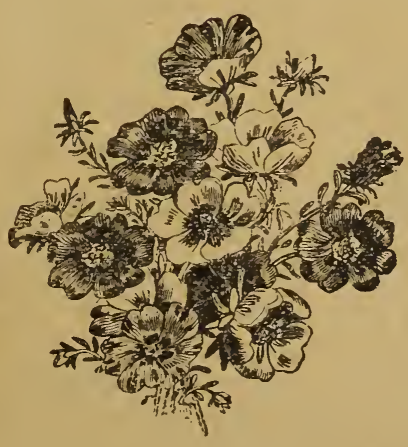

Portulaca.

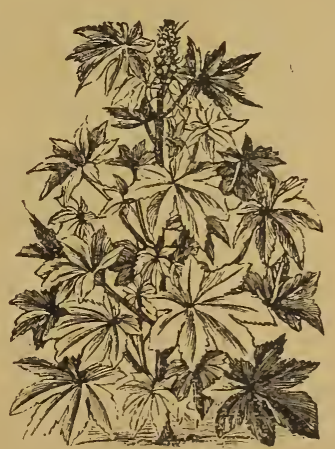

Castor Oil Bean. 


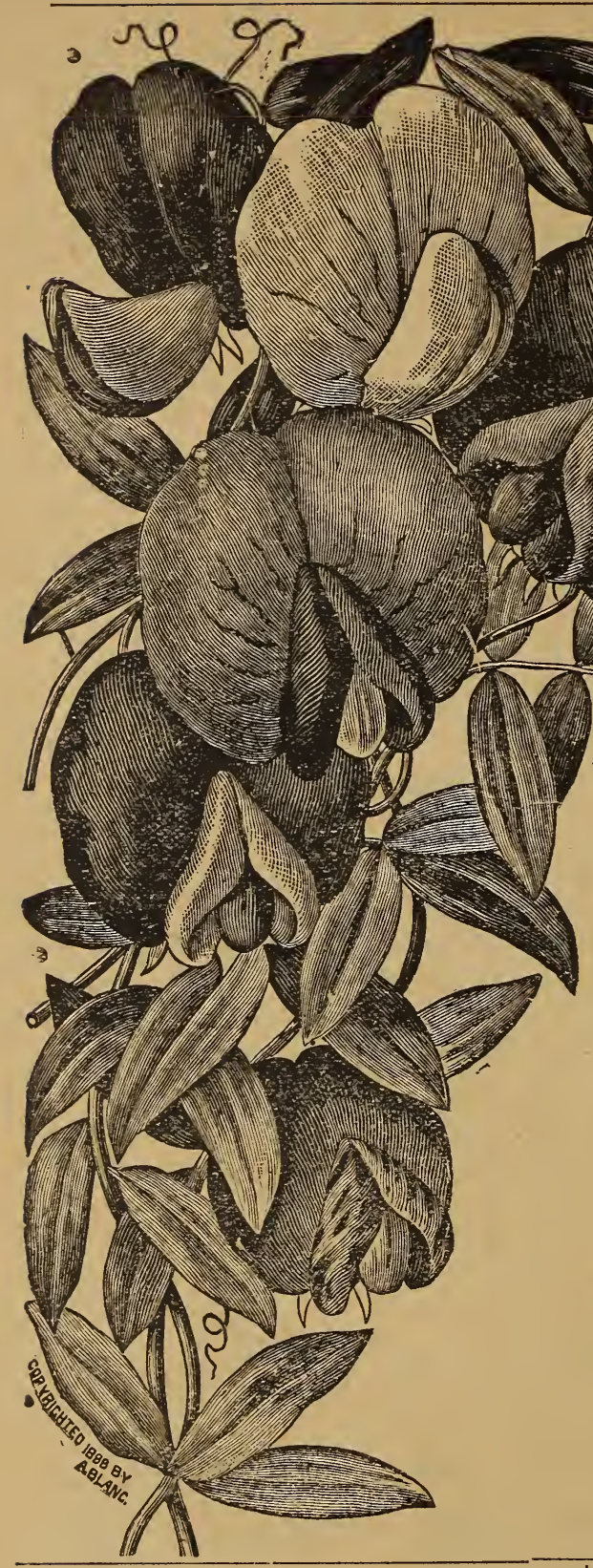

148. Empress of India.-Clear rosy pink, wings white, large. An improvement in size, form and substance on old Painted Lady. Pkt., 5c.; Oz., 15c.

149. Mrs. Gladstone.-Flowers large, of perfect form, and of most delicate and beautiful pink. One of the most elegant
26 no 1670 10 S

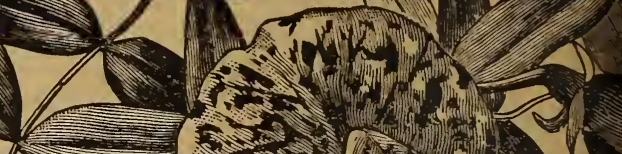

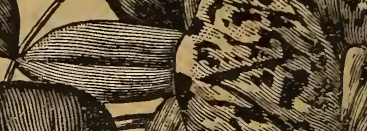
H. (1)

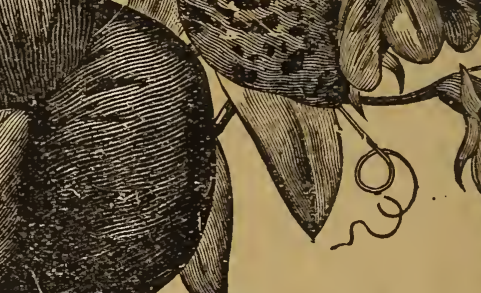

(a) 203

EGKFORD'S New Sweet Peas.

Sow thickly, and plant two inches deep, as early as possible in the spring. Furnish support early. They luxuriate in cold, moist soil, and in damp season. Six feet. Hardy annuals. The characteristics of these Peas are that, while they possess the same delicious perfume as any of the ordinary varieties, the flowers, produced in profusion, are nearly double the size, are most perfect in form, and present combinations in markings and colors heretofore unknown in this exquisite flower.

145. Miss Blanche Ferry.-A new Sweet Pea of great merit. Immense pink and white flowers of perfect form, possessing deep, rich coloring. More fragrant than Painted Lady. Earliest by ten days; dwarf, compact growth; requires no support; profuse bloom. Pkt., 5c.; oz., 15c.

146. Indigo King.-Rich indigo black and blue, fine large flower. Pkt., 5c.; oz., $15 \mathrm{c}$.

147. Isa Eckford.-Creamy white, with rosy pink. Pkt., 5c.; oz., 15c.

and beautiful flowers in the list. Pkt., 5c; oz., $15 \mathrm{c}$.

150. Adonis.-Rosy pink, the wings a little darker than the standard. Both wings and standard are long, but comparatively narrow. A showy flower. Pkt., 5c.; oz., $15 \mathrm{c}$. 


\section{Sweet Peas.}

151. Butterfly.-White or light blue, and shaded with lavender, becoming a decided blue on the edge of the standard. A striking peculiarity of this variety is that the standard presents the appearance of a butterfly's wings, being deeply cut on either side. Pkt., 5c.; oz., 10c.

152. Captain of the Blues.-One of the largest blue flowered sorts. Standard very broad and bright purple-hued; wings broad, expanded and lighter and brighter blie than the standard. Pkt., 5c.; oz., $15 \mathrm{c}$.

153. Primrose.-A near approach to a yellow Sweet Pea; quite novel and distinct in color; the standards and wings pale primrose yellow. Pkt., 5c.; oz., 20c.

154. Queen of England.-Grand pure white flowers, of extra large size, and specially choice. Pkt., 5c.; oz., $15 \mathrm{c}$.

155. Invincible Scarlet.-Claret, crimso.1 and scarlet. Pkt., 5c.; oz., 15c.

156. Princess Beatrice.-Blush pink. Most delicate and charming. Pkt., 5c.; oz., $15 \mathrm{c}$.

157. Perkins' Special Choice Mixed. -This is made up from the above named varieties, and includes many of the most costly sorts. Pkt., 5c.; oz., 15c.

158. Good Mixed.-A good collection, b'st it does not include as many of the expensive varieties. Pkt., 5c.; oz., $10 \mathrm{c}$.

One oz. of seed will sow $10 \mathrm{ft}$. of drill.

159. Grand New White Sweet Pea, which has been named "EMILY HENDERSON." Its color is as pure as the driven snow. We have had several improvements in late years in White Sweet Peas, but "Emily Henderson's" outrivals all competitors by nearly two weeks, and it also holds longer-a veritable "cut-andconse-again" to the end of summer. Pkt., 5 c.; oz., 20 c.

\section{New Double Sweet Peas.}

160. Duke of Clarence.-A beautiful hooded variety, with flowers of the largest size. Color, a brilliant shade of rosy claret, making it desirable for bunching; fine. Pkt., 5c.; oz., 20c.

161. Splendor. - Most appropriately named, superb, rose-colored blossoms, richly shaded with crimson. Spplendid large flowers, finely formed, bright and clear. Pkt., 5c.; oz., 20c.
162. Pure White.-With large flowers. Very popular with Sweet Pea growers. Pkt., 5c.; oz., 20c.

163. Boreatto.-Large expanded form; the flowers are of a rich, deep maroon or dark claret color. One of the most distinct varieties and very desirable for bunching with the lighter colors. Pkt., 5c.; oz., 20 c.

164. Apple Blossom.-Large, pointed flowers, shaded pink and rose, with the prevailing tints deepest in the clearly veined standards, most appropriately named. Pkt., 5c.; oz., 20c.

165. Butterfly.-White laced with lavender. Pkt., 5c.; oz., 20 c.

166. Sensitive Plant (Mimosa).-The Sensitive Plant is very chaste and elegant in foliage, the leaves being delicately pinnated, while it bears attractive small pink flowers, in globose heads. It affords miuch amusement not only to children, but to those of larger growth, by its sensitive character; even when slightly touched, the leaves instantly close and droop. Easily grown in any garden; it will prove a ccnstant source of interest. $5 \mathrm{c}$.

167. Snapdragon (Antirrhinum).-The Snapdragon is an old favorite border plant, with dark and glossy leaves, and large curiously shaped flowers, with finely marked throats. They have been much improved by careful selection, and now are really magnificent flowers. They bloom the first season from seed sown in the spring, but the blossoms will be much stronger the second season; succeeds best in dry, loamy soil. Tender, perennial, $1 \frac{1}{2}$ to 2 feet high. Fine mixed, all the best colors. 5c.

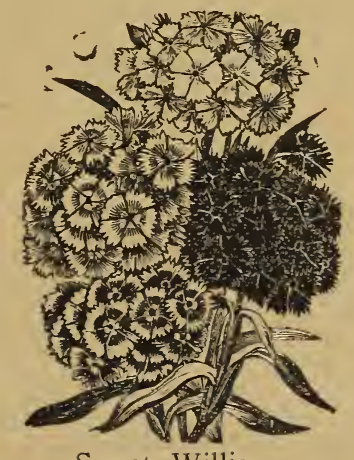

Sweet William.

Sweet William (Dianthus Barbatus). A bed of fine varieties sports into an endless variety of colors, and presents a 


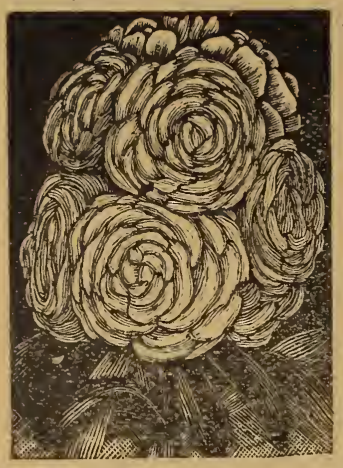

Stcck.

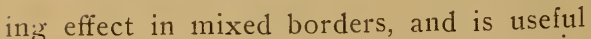
for forming bouquets of cut bowers in connection with $h_{1}$ other colored flowers. Hardy annual; two feet high. Double purple, $5 \mathrm{c}$.

171. Virginia Creeper (Hedera).-The Virginia Creeper, or American Woodbine, is hardy, very ornamental, of rapid growth and the foliage is luxuriant and beautiful. It is often made to cover the walls of houses forty or fifty feet high, clinging by its tendrils. The flower is reddish green, not showy, but is succeeded by clusters of nearly black berries, at which time the tendrils and stalk turn to a rich crimson color. It is exceedingly ornamental and conspicuous in October, after the first frost. $5 \mathrm{c}$.

172. Verbena (Mammoth Strain). This distinct and superb class of Verbenas is a remarkable improvement on the older varieties: It produces flowers of an enormous size, the florets being fully 1 inch in diameter, with clearly defined margins and white eyes. Pkt., 5c.

173. Niveni-White, sweet scented. Pkt., 5c.

174. Hybrida-Fine mixed. Embraces all colors. Pkt., 5c.

175. Mammoth Strain. 5c.

176. Striped, 5c.

177. Virginia Stock (Malcomia) Hardy annuals, very useful for bordering or edging. A continual succession of blossoms may be kept up the whole season by sowing at intervals through the spring and summer. The flowers and plants are quite as desirable as the Candytuft. Grows about nine inches high. Red and white mixed. Pkt., 5c.

178. Violet (Viola).-Well-known, free flowering, hardy perennial, easily grown from seed. Succeeds best in a partially

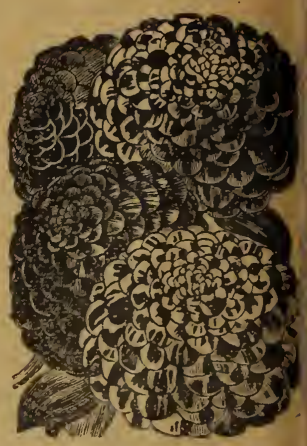

Zinnia.

shaded, moist situation. Height, 6 inches. Sweet scented, flowers blue, fragrant. Pht. $5 c$.

Wall Flower (Cheiranthus Chetri).The large, massive spikes of the Wall Flower are very conspicuous in beds and borders, and are very useful in making bouquets. They are deliciously fragrant, perfectly double, and combine many shades of color, the orange, purple and chocolate predominating. Sow the seeds early in hot bed, and while the plants are small pick them out into pots, and sink the pots into the earth. On the approach of cold weather, remove the pots to the house, and they will bloom all the winter. Tender, perenniial, $1 \frac{1}{2}$ feet high.

179. Fine mixed, $5 c$.

180. Mixed, double, $10 \mathrm{c}$.

181. Xeranthemum. - Showy, hardy annuals, of the earliest culture, and the flowers of various colors, from their peculiar dry character, may be preserved for a long time. Two feet high. Mixed. Plit., 5c.

182. Wild Cucumber.-Although not neiv, we do not hesitate to give this climber prominence. We know of no vine so va!uable for covering unsightly objects, tree stumps, back fences, etc. It grows rapidly, attaining a height of from 20 to 30 feet, producing an immense quantity of green foliage. Soak seed 24 hours before planting. Pkt., 5c.; 表, oz., 10c.; oz., 20c.

Zinnia.-A very showy plant, with large double flowers, which, when fully expanded, from hemispherical heads, become densely imbricated, and might easily be mistaken for dwarf Dahlias. The colors run through all the shades of carmin:, lilac, scarlet, purple, crimson, yellow to pure white. If any single blosscmis appear. they should at once be pulle.l up. Sow the seed early in spring in 
open ground and transplant to one and a half feet apart, in good, rich, soil, or start under glass for early blooming. Half-hardy annual; $1 \frac{1}{2}$ feet high.

183. Scarlet, 5c.

184. Single mixed, English, 5c.

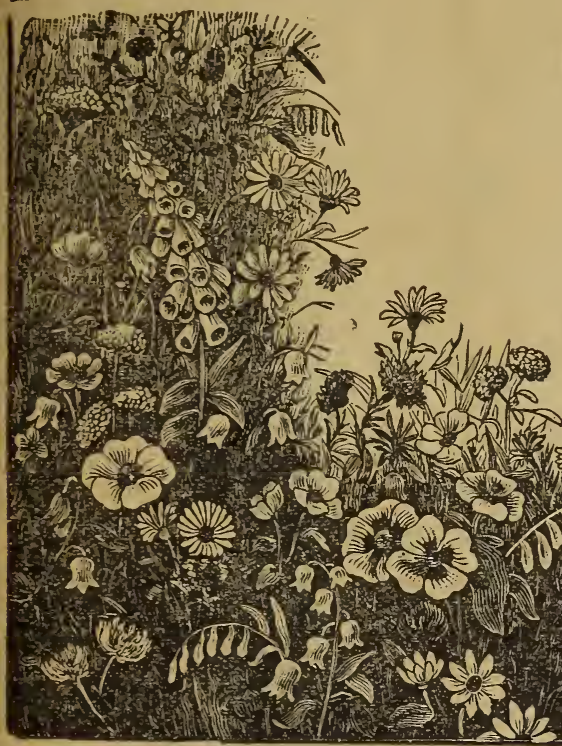

\section{Peanuts.}

Iniported direct from Germany. A desirable variety, because it is early and a gcod bearer; its growth perfectly erect and therefore much more easily cultivated. Also in harvesting all the peas hang to the roots and can be rapidly gathered. Cin be planted close in the row and in drills, yielding largely per acre. This variety can be grown in the north.

Culture.-Select warm soil, if possible of a calcareous (lime) nature; mark out rows three feet apart, and drop the nut about a foot apart in the rows, one in a place, and cover with two inches of soil. Y.u need not remove the hulls or shucks before planting. Plant as soon as frost is over.

Cultivate and hoe freely, leaving but one plant in a place; keep the soil well mellowed up around the plants when seeds (nuts) are forming.

Do not be alarmed when you seen the flowers insert their ovaries into the mellow soil to complete their growth and form nuts.

Before freezing weather, dig or pull the plarts. Hang under a shed to cure. Then
100. White, 5c.

186. Double mixed, English, 5c.

Tu those who cannot bestow the necessa:y care required in a neatly laid out flower garden, the "Wild Garden" presents a substitute, which for its unusual varied effect, for cheapness and small amount of labor necessary for its construction, has no rival We have had many satisfactory evidences of the estimation in which the "Wild Garden" is heli from those who used our seed the past season.

187. Mixed Garden Seeds are mixtures of over 100 varieties of hardy flower seeds, mixed together, and wherever plarted will ensure something new almost every day. Pkt., 5c.; $\frac{1}{2}$ oz., $15 \mathrm{c}$; oz., $30 \mathrm{c}$.

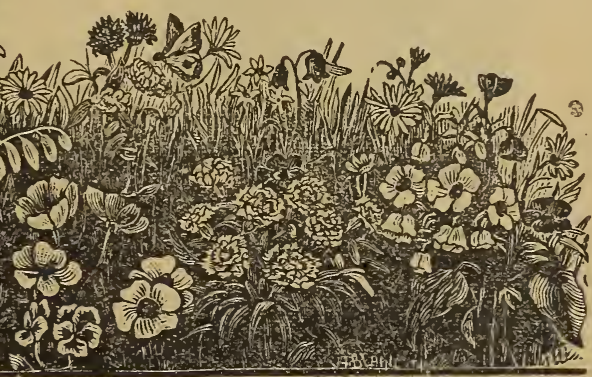

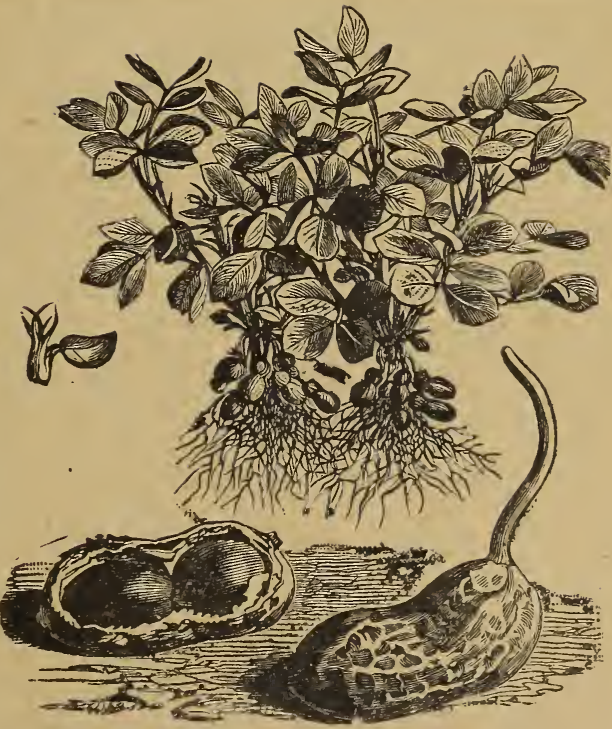

German Peanut.

gather, clean, and sort the nuts. Pkt., $5 \mathrm{c}$; $\frac{1}{1} 1 \mathrm{j} ., 15 \mathrm{c}$; 1 b., 50c.; by mail, 55c. 


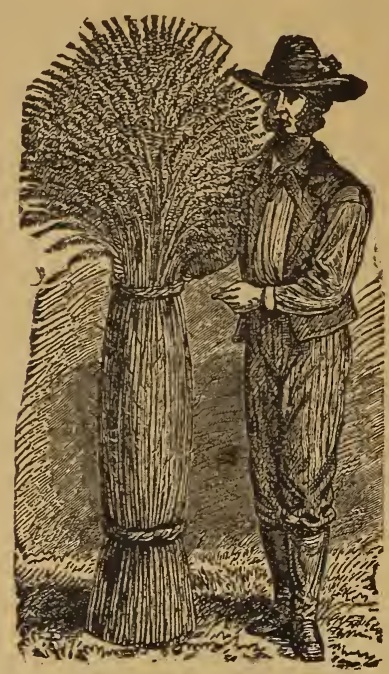

New Popular and Standard Varieties

\section{OF \\ SEED OATS.}

The Iincoln.-The following are a few points of excellence: It is very productive, having in all instances yielded more to the acre than any other sort grown in the same locality; in one case it yielded 174 bushels from a single bushel of seed. It is very early, and has thus far proved itself rust-proof. It stands up better than any other sort; it is best for feeding, on account of its thin hull, heavy meat and soft nib. It is best for oatmeal or grinding, for the same reasons. Two lbs. (by mail, postpaid), 25c.; peck., 30c.; bushel, $\$ 1.00$.

Black Tartarian.-The Black Tartarian is of the best variety of Black Oat in cultivation. The grain is black and is produced on the side of the head. Grown from imported seed. Two lbs. (by mail, postpaid), 25c.; peck, 30c.; bushel, $\$ 1.00$.

The Newmarket.-We believe it will soon become a standard variety, and we unhesitatingly state that the NEWMARKET is not surpassed by any variety in th's country for PRODUCTIVENESS AND STANDING UP QUALITIES. It is a White variety, with large branching heads. Kernels large, of medium length, uniform and taper pointed. Straw of good length and very seldom goes down. From the start these oats make a vigorous growth, and when out in head were the admiration of the neighborhood. The straw is tall and very stiff, standing up well, and free from rust and smut. The grain is plump. and heavy and of a beautiful white color. These oats are second to none in yield. We have a fine lot, but look to an increased demand that may take it all before the season is past, and wculd advise those who contemplate ordering to do so early. We will sell as follcws while our present stock holds out: 2 lbs. (by mail, postpaid), 25c.; bushel, $\$ 1.10$. Seamless bags for above, 20c. each.

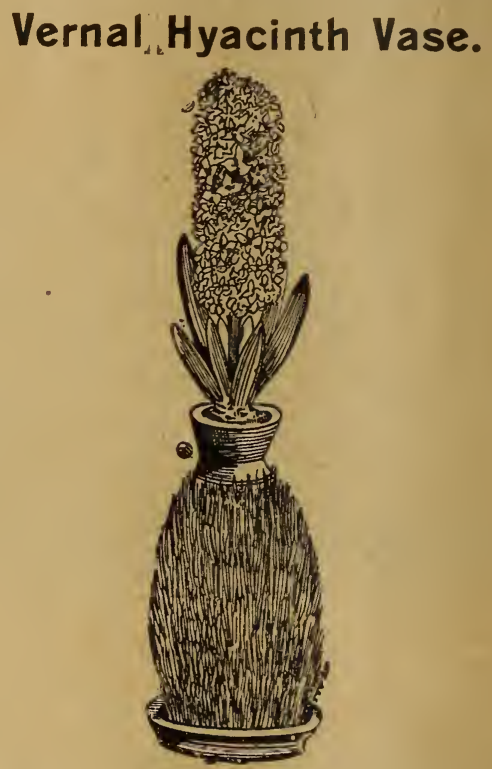

Made of terra cotta. Immerse the vase for a day in water, then sprinkle with Timothy seed; within a few days' time it will cover the vase with a bright green growth; of course, aways keep the vase filled with water. Hyacinths can be grcwn in these just the same as in the regular Hyacinth glasses. Price, $50 \mathrm{c}$. Smaller ones at 25c. We furnish enough seed with each vase to keep it green for six months.

Wood Labels for plants, 4, 5, 6, 7 and 10-inch, 25c. per 100.

Raffia.-The best material for tying plants, vines, etc., 40c. per $1 \mathrm{~b}$.

\section{TO OUR PATRONS.}

We would respectfully draw your attention to the announcements of the several advertisers, who are among the leading business houses of Winnipeg, and who w'11, no doubt, give entire satisfaction to any who may deal with them.

Give them a Trial Order. 


\section{New National Broadcast Seeder,}

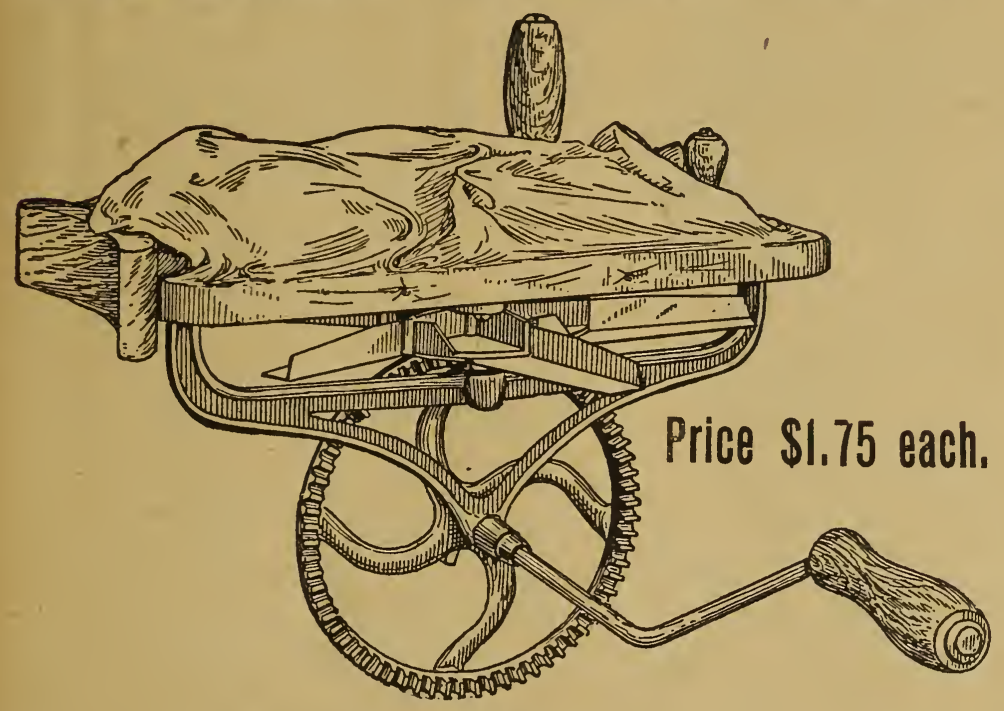

Combines every good feature of every other Broadcast Seed Sower and is distinct and superior in many respects. The cheapest, simplest, strongest, most durable and most accurate and handsome Seeder made.

It will sow wheat, rye, oats, rice, flax, millet, turnip seed, clover seed, grass seed, including light grasses; in fact, all kinds of seed broadcast. Also plaster, fetilizer, salt, ashes, etc.

No careful, economical farmer will continue to sow his seed by hand (the old way) when he can get one of these machines at our low price. They will save their cost daily in the saving of seed, to say nothing about saving of time and more even distribution, which will have great effect on the crop. Price $\$ 1.75$ each.

In the New National we have one cog wheel 7 inches in diameter and a small pinion. In the old style machines four cog wheels were employed, and they frequently wear out or break. The frame is so constructed that it allows the minimum of weight with greatest strength and rigidity. The feed is from the centre of the base and the base is bevelled to run the seed out very clean.

The New National is finished in the national colors-red, white and blue. It is the handsomest as well as the best machine on the market.

It will sow at a round wheat or rye, 50 feet; buckwheat, 45 feet; flax seed, clover or millet, 36 feet; grass seed, 20 to 36 feet; other seeds, etc., according to their nature and condition. By the superior construction of the hopper and attachment of the sack it sows out clean. The old style seeders don't do this. Full directicns with each machine.

Farmers need this National machine on account of the seed it will save, the superior work it will do, as well as the ease of doing it. Many up-to-date farmers will lay aside their old machines aud buy this up-to-date machine on sight.

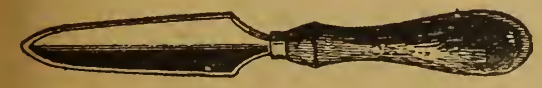

Garden Trowels.-Light and handy, 6 in., each, 20c.; by mail, 25c. Polished steel, 7 in., each, 30c.; by mail, 35c.

Garden Lines of the best material, 50 ft., 25c.; by mail, 35c.; English make, 60 $\mathrm{ft}, 45 \mathrm{c}$; by mail, $55 \mathrm{c}$. 


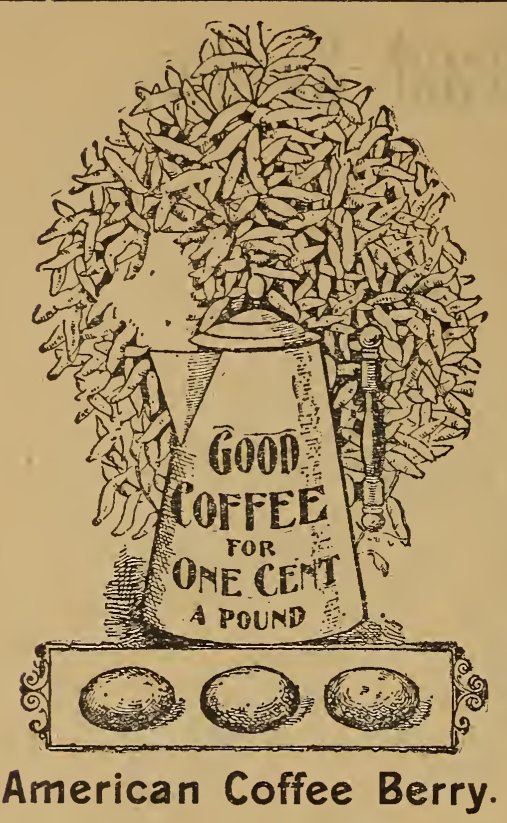

Coffee (and very good Coffee, too) for One Cent a pound.

When blended and ground with good coffee, half and half, its presence can scarcely be detected. It is prepared just like coffee. The beans, which are about the size of the real coffee berry, are roasted, ground, and used either alone or mixed with coffee, as may be preferred. The plant is about three feet in height. It fruits from the ground up, and on the limbs in every direction. The pods, of which there are from 150 to 250 on a plant, touch each other, so closely together do they grow. The pods contain on an average from two to three beans.

Culture.-The rows should be planted three feet apart, one berry every ten inches apart in the row. Cultivated like corn or beans, and should be planted about the same time. Price-Pkt., 5c.; $\frac{1}{4}$ 1b., 20c.; 1b., 75c.; by mail, postpaid.

\section{Excelsior Lawn Dressing.}

Is a fertilizer specially prepared for LAWNS, promotes its LUXURIANT GROWTH, and the DARK GREEN COLOR so greatly admired. It is not only the MOST PERFECT LAWN DRESSING that has been devised, but it is the most pleasant to handle, being non-odorous, so that its liberal use on the lawil cannot be detected by any unpleasant odor Being dry and fine it is easy to apply, and imparts such a vigorous growth to the grass that two or three applications during the season at the rate of only one pound to each 100 square feet of lawn keeps the grass in flourishing condition throughout the season, and enables it to withstand the effect of the hot sunımer sun. This we believe cannot be excelled. In seeding down a new lawn, apply broadcast, double the amount above mentioned and rake it in thoroughly before sowing the seed.

FOR HOUSE PLANTS, dissolve one teaspoonful of Fertilizer in one quart of water, and use the solution freely around the plants, stirring the solution while applying. It may be applied as often as the plants seem to require it; once every week or ten days until they are in the desired condition.

THE USE OF EXCELSIOR LAWN DRESSING ON FLOWERS.-By its judicious use, the health, vigor and free blossoming character of the flowers will be greatly enhanced. The result of its use on flower beds is quickly seen by the dark green leaves and high color of blossoms produced. To fertilize bedding plants, stir a teaspoonful, or more, according to the size of the plant, into the soil about each plant, and repeat two or three times during the season. After the fertilizer is used water the plants freely. 1 lb., 10c.; 3 1b., $25 \mathrm{c}$.

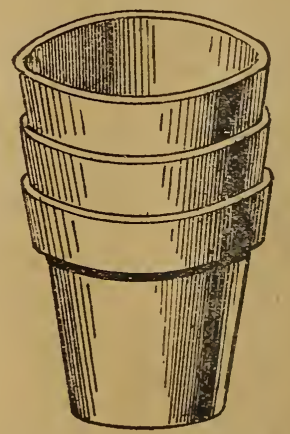

FLOWER POTS.

Without saucers, 3-in., 30c. per doz.

Without saucers, 4-in., 40c. per. doz.

Without saucers, 5-in., 50c. per doz.

Without saucers, 6-in., $80 \mathrm{c}$. per doz.

Without saucers, 7 -in., $15 \mathrm{c}$ ea., $\$ 1.50 \mathrm{doz}$.

Without saucers, 8-in., 20c ea., 2.00 doz.

Without saucers, 10 -in., $25 \mathrm{c}$ ea., $2.70 \mathrm{doz}$.

Without saucers, $12-i n ., 30 \mathrm{c}$ ea., $3.20 \mathrm{doz}$.

Saucers for Flower Pots-All sizes, from 5 -inch up, at half price of pots. 


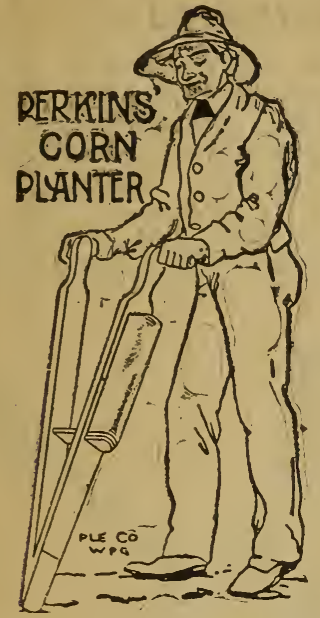

\section{Perkins' Corn Planter.}

The best and cheapest Corn Planter on earth. Can be set to drop any number of grains in hill. Price $\$ 1.40$; if by express, purchaser pays charges.

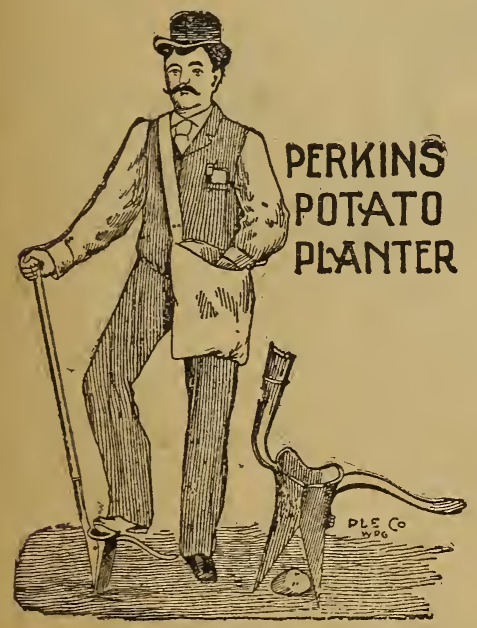

\section{Perkins' Potato Planter.}

This is a wonderful invention. A great labor saver. Cheap as dirt. It is very important in planting potatoes that they be placed in moist soil and covered before the soil dries out. Ordinarily the holes a made or furrows turned. This the Perkins' Planter does perfectly. If a horse is used, and the soil exposed to the hot sun for a day, the soil soon dries. Next, the potatoes are dropped, and per- haps they are left to blister in the sun. They are then covered up at uneven depths. The dry ground draws any moisture that may be left in the seed away from it, and the result is no crop. Moral - Use the Hand Potato Planter and take no such chances, for it drops the seed in $o$ the moist soil and covers it at the same time. We urge you to give the Perkirs' Planter a trial. They are gems of th: first water. Price, $\$ 1,25$; if sent by express, purchaser pays charges.

PLANTING BAGS.-To hold the seed, as shown in cut, $85 \mathrm{c}$.

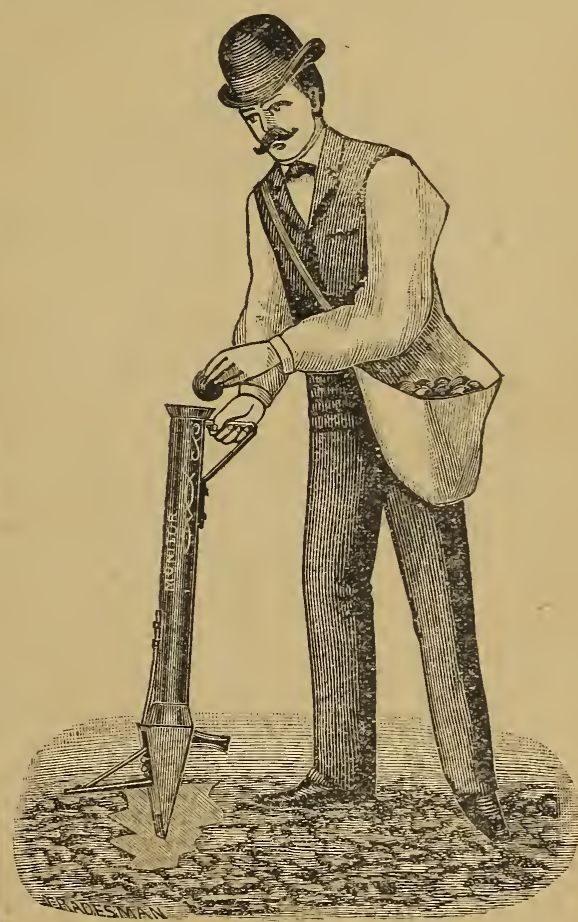

\section{The "Peerless" Tubular Potato Planter.}

The "Peerless" is the lightest tubular Planter made. Its spring closed jaws are specially designed to enter the soil easily, yat open wide enough to drop the largest seed.

The dropping lever, or dump, is adjustable for any depth of planting. It is braced to avoid bending and has a broad flat bottom, well adapted to the soft soils for which the planter is intended. The conveyor tube is galvanized iron. Price \$2.00. If sent by express buyer pays charges. 


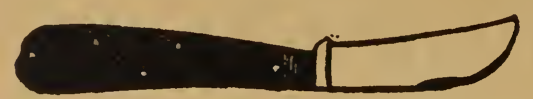

Pruning Knives.-Stag handle, crooked blade. Each, $\$ 1.25$. Smaller size, $\$ 1$.

\section{POTATOES FOR SEED.}

WE SHALL SHIP as early as is safe from frost. We shall ship when requested any time customers wish to take their own risk. On late orders it will save time to state, in case supply of some kinds is exhausted, whether you wish us to return money or substitute other sorts of same value.

Burpee's Extra Early Light Pink Prices on appl Puritan Early ............ White $\}_{\text {cation. }}$ Post paid Pk. Bus. American Wonder ...... White 3 lbs. 25c. 50c. $\$ 1.50$ Early St. George..........." " 3 lbs. 25c. 50c. $\$ 1.50$ Early Kidney Ash Leaf.. " "3 lbs. 25c. 50c. $\$ 1.50$ Maulis Early Thoroughbred " $3 \mathrm{lbs}$. 30c. 50c. $\$ 1.50$

Two new sorts originated in Manitoba, both from the same seed-ball:

No. 1., Pearly Flower, Early, White.

No. 2, Manitoba Beauty, Medium, Pink.

The great peculiarity about these potato $2 s$ is their shallow eye, therefore scarcely any waste in paring them; stock limited; first come, first served. $3 \mathrm{lb}$. , by mail, post paid, 25c.; peck, 50c.; bushel, $\$ 1.50$. Buyer pays carriage on pecks and bushels.

On other varieties wanted, write for prices.

The above fine varieties are very choice, and all grown near Winnipeg last year by one of the best market gardeners, therefore they are acclimatized, and will give good satisfaction.

On pecks and bushels buyer pays carriage. Bags in which to ship potatoes, $5 c$. and $10 \mathrm{c}$. each. Mixed potato seed imported direct from Germany, 5c. pkt.

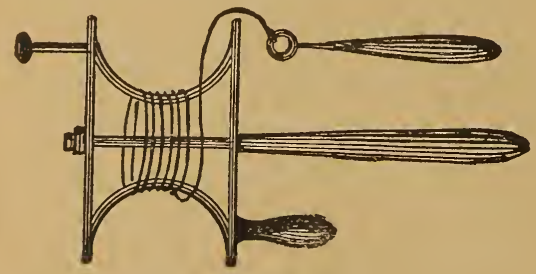

Garden Reels.-Iron, with stake, each, 75c. Larger size, $\$ 1.00$.

\section{Herbageum.}

Keeps horses in fine condition. It loosens the hide. It keeps them right in their water. It cleans out worms and bots. Hens lay more eggs when fed Herbageum -especially in winter. It makes young chicks grow; it fattens turkeys. The great Fattener for Cattle and Pigs is Het bageum-keeps them healthy. Price, 4 lk. pkt., 50c. TRY IT.

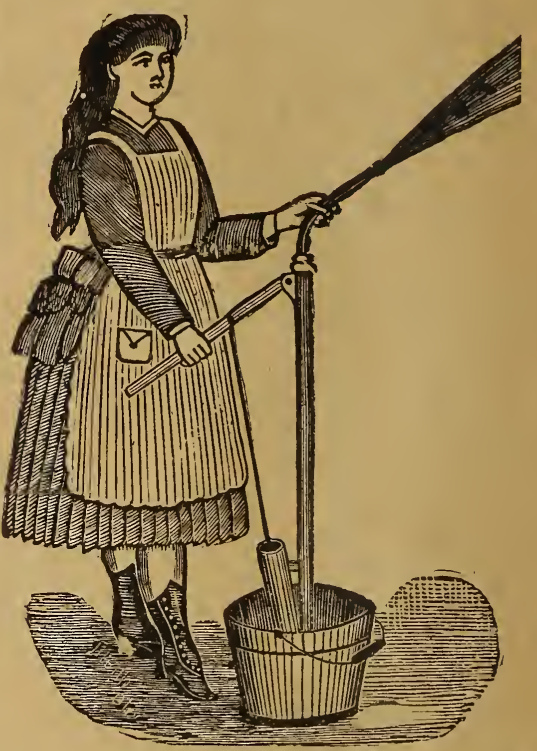

\section{The Dandy HAND FOREE Rump}

This pump is made of the very best material. "It supplies a long-felt want, viz., a pump that is serviceable, and one that can be sold at a price that will bring it within the reach of all. It is always ready for use, and not liable to get out of order. It throws a stream 30 feet or more. In this age of insects it is invaluable for spraying apple, pear, peach or plum trees, grape vines, etc., or windows. $\$ 1.50$ by express at purchaser's expense. (See cut.)

\section{Perkins' \\ Granulated Bone Meal.}

Imported Direct from Chicago.

It is about the size of wheat. Feed one handful for every five fowls daily or every other day. In either manner it furniches valuable food for poultry at all seasons of the year. Price, $4 c$. per lb. 


\section{THE "IRON AGE" WHEEL HOES AND SEED DRILLS.}

\section{THE "IRON AGE" Double Wheel Hoe, with Cultivator Teeth, Plows and Rakes.}

Packed Weight $40 \mathrm{lb}$. Price $\$ 9.00$.

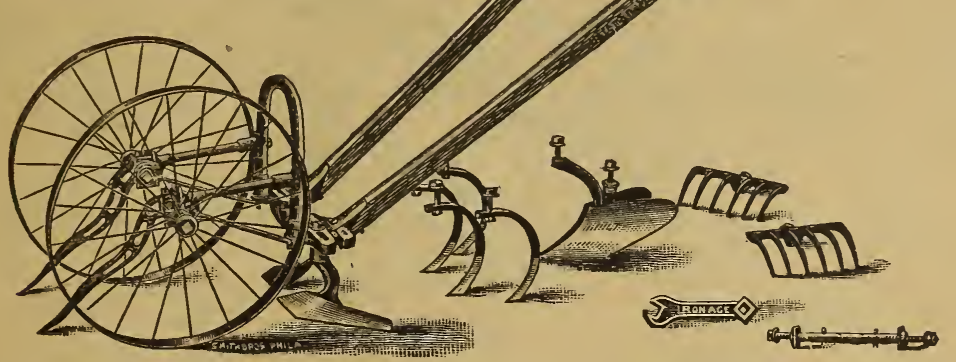

Among the principal labor saving tools in the hands of the market gardener and farmer must be considered Wheel Hoes. They have done away with the backbreaking and time-killing methods of the ciden time, one man performing in a more thorough manner, and with greater ease to himself, the labor of several men.

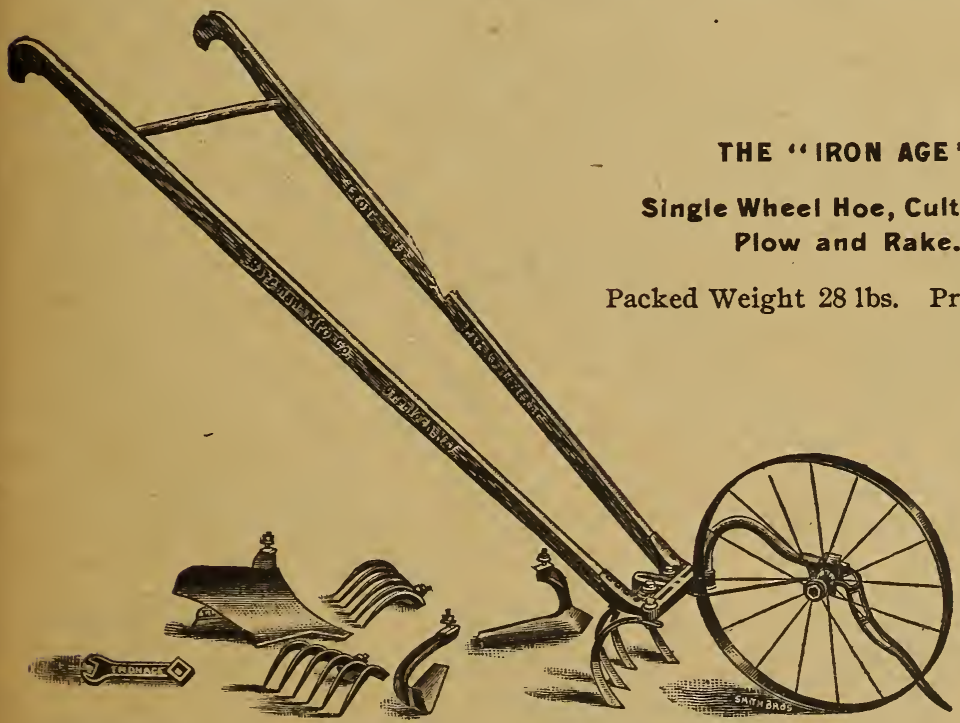

This tool is, in regard to the work done, alrrost a counterpart of the Double Wheel Hoe, and the same remarks as to its construction, extreme lightness and ease of operation will apply with equal force.

In addition, its lower price, less weight anc' increased steadiness, given by a single wheel, make strong arguments for this tool. With this single wheel tool, spaces of exceedingly narrow width can be worked, even using but one cultivator tocith. With the large plow attachment, deep furrows can be opened or closed; potatoes, celery and other crops hilled-in short, all such work usually accomplis hed by a special plow. 


\section{The "Iron Age" Combined Seed Drill and \\ Wheel Hoe.}

Packed Weight 50 lbs. Price $\$ 14.50$.

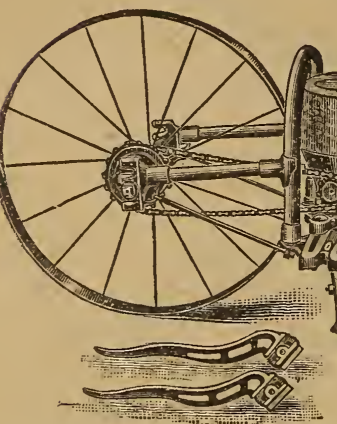

In designing our Seed Drill attachment for the Double Wheel Hoe, we have kept in view simplicity of construction, convenience of adjustment and perfection of work.

The drill attachment is complete in itself, and when put in place requires but two bult s to secure it; the single wheel is then put in position, the chain run on and the drill is ready for operation. The seed slide and its index adjustment to sow the various seeds is similar to that used on our well known New Model Seed Drill, while the agitator is simply a revolving brush, of selected bristles, which will not injure the seed, wear a long time, and can be cheaply replaced.

The combined Drill includes all the attachments shown in the cut above. It is a whole tool house of itself. It plows, levels, furrows, sows, covers, rakes, cultivates, hoes and hills, and does each and erery operation in the most satisfactory manier.

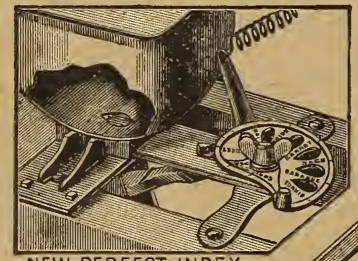

NEW PERFECT INDEX

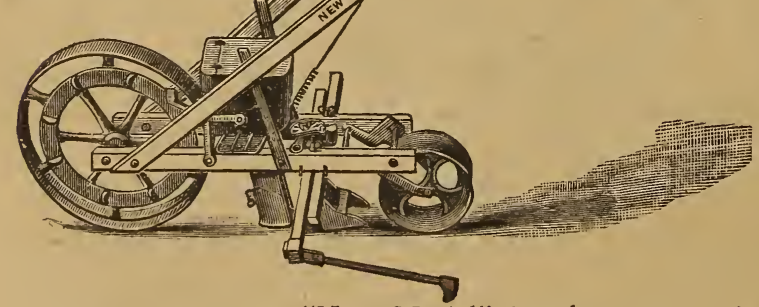

THE

\section{"NEW MODEL"} SEED DRILL

The record of the "New Model" has been so entirely satisfactory, and its place as one of the leading drills has become so firmly established, that we are almost tempted to discard the word "New." It is surprising to see how quickly it has bcen adopteil by the seedsmen and market gardeners as an old friend.

Each Drill crated and carefully packed for shipment. Packed weight about 45 lbs. Price, $\$ 10.00$. 


\section{PLANET JR. GARDEN TOOLS FOR 1901.}

These Standard Goods for 1901 have been placed in our hands for sale; if anything is wanted in the "Planet Junior" goods, kindly let us know. If we have not got it in stock, we can procure it at short rictice.

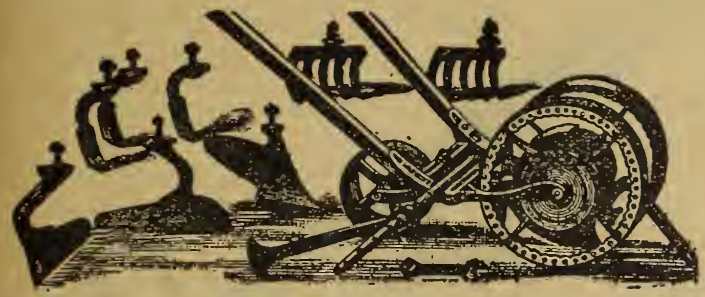

THE PLANET JR. NO. '

\section{Combination Drill and Wheel \\ Hoe, Cultivator, Rake and Plow.}

Price boxed ready for shipping,

This has long been the most popular combined tool made. As a seed sower it is identical with the No. 2 "Planet Jr." Drill, except in size, and has all its merits, its strength, durability, ease of operationand perfection of work.

PLANET JR. NO. 2 .

\section{Double Wheel Hoe, Cultivator, Rake and Plow}

\section{List, $\$ 9.75$.}

This tool, first offered for '98, combines in itself the good points in its predeces: sors, with valuable new ideas. It has 11 in. wheels, which can be set at four differ-

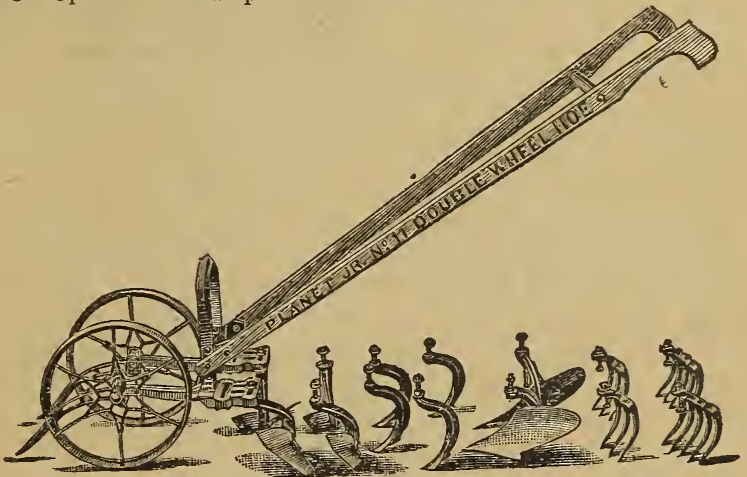
ent distances apart; the frame is malleable, with ample room for tool adjustment, and can be set at three different heights. A pair of model rakes and a pair of new style hoes are added to the usual equipment-seven pairs of tools in all. The whole set shown in the cut goes with the complete tool. Our No. 12 double wheel hoe is the same as No. 11, shown in cut, less one pair of hoes, and the rakes.

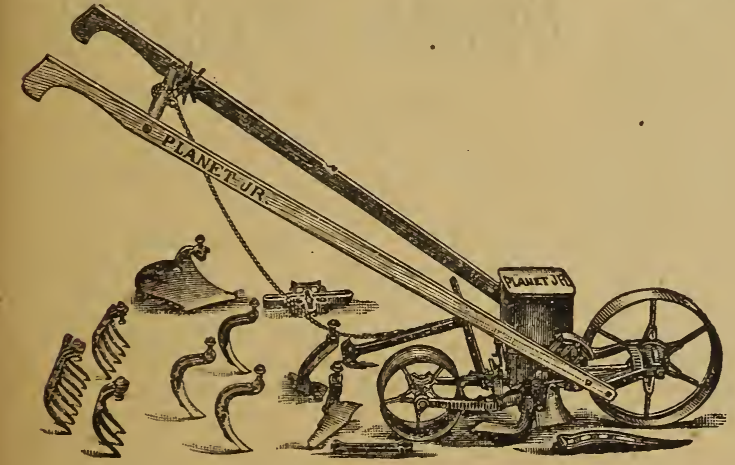

PLANET JR. No. 4.

Combined Drill Dropping

Seeder, Single Wheel

Hoe, Cultivator,

Rake and Plow.

This style of seeder holds two quarts. It drops in hills of $4,6,8,12$ and 24 inches apart, and in drills any thickness, handling the smallest paper of seed perfectly, and is simple, durable and very light running. Throws out of gear instantly by simply raising the handles.

Price, complete, $\$ 13.50$, boxed ready for shipping. Shipping weight, 55 lbs. 


\section{" PLANET JR." TWELVE-TOOTH HARROW, CULTIVATOR \& PULVERLIZER}

Price, with wheel complete, $\$ 13.00$

“PLANET JR." No. 15, Single Wheel Hoe, Cultivator, Rake and Plow.

Price \$9.50, boxed ready for shipping.

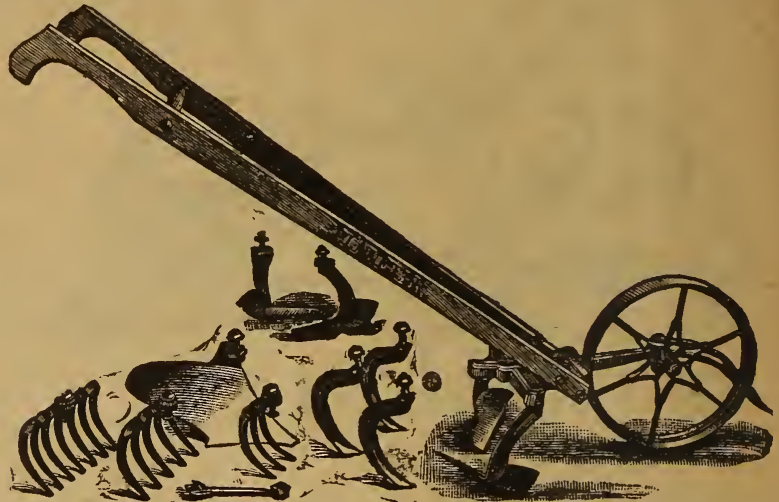

This latest and best Single Wheel Hoe, irıproved for 1901, has an 11 inch wheel, with broad face, and a conveniently arranged, and a very full set of tools, several of them being of new, special design, such as we have found to perform Wheel Hoe work in the very best manner. It is very light and strong and easy running; has three more tools than the old Planet Jr., and does a much greater variety of work, and does it better. The tools are a well-shaped plow for plowing, marking out, covering and late cultivation; a pair of neat 4 -inch shield hoes, just right for hoeing in rows from 9 to 12 inches; and a large pair for wider work, and three cultivator teeth. Also a set of three rakes, just right for $6,9,12$ and up to 16 -inch rows, with two arranged side by side; the rakes are just the thing fur preparing ground for the Seed Drill. A practical leaf guard completes the equipment. The frame changes in height, and the wheel to the other side of the frame, when both sides of the row can be hoed at one fassage.

Our No. 17 Single Wheel Hoe is same as No. 15, shown in cut, less one pair of hces and the rakes. List, $\$ 7.00$.

\section{LICHTNING BAG AND SACK HOLDER}

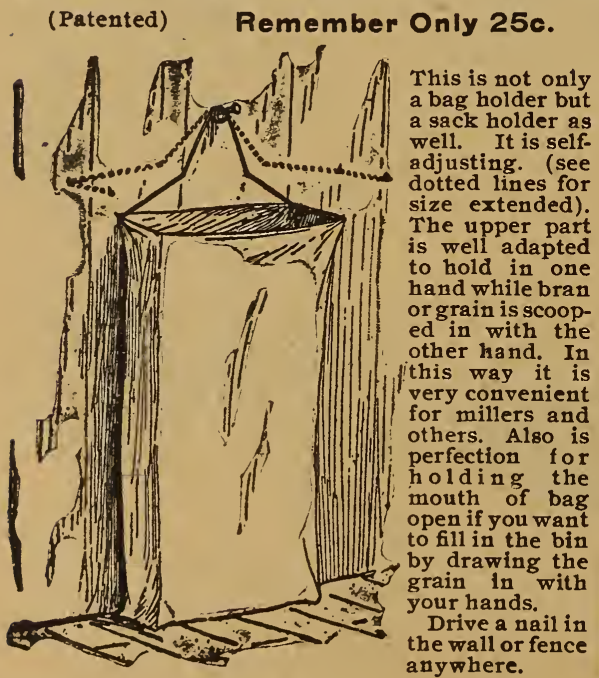

PERKINS' Granite Crystal Grit

SHARP

HARD
FREE FROM DUST.

Lasts Longer and more Economical than other Grit.

It is the Sharpest and Garest Grit known. NO WASTE.

NO WASTE.

We need not enlarge upon the value of grit for poultry. Every poultryman knows how necessary it is to his welfare. To obtain best results, grit must not only be sharp when eaten, but must remain sharp under the action of the gizzard. It is at this point that our Granite Crystal Grit proves itself superior to all others, its hard texture and thousand cornered crystals serve to sharpen each other while also grinding the food for the digestive organs. 2c. per $1 \mathrm{~b} ; 100$ lbs., $\$ 1.85$. 


\section{THE "ACME" SEED DRILL.}

To Suit Different Kinds of Seeds.

Seed-box Quickly and Easily Adjusted.

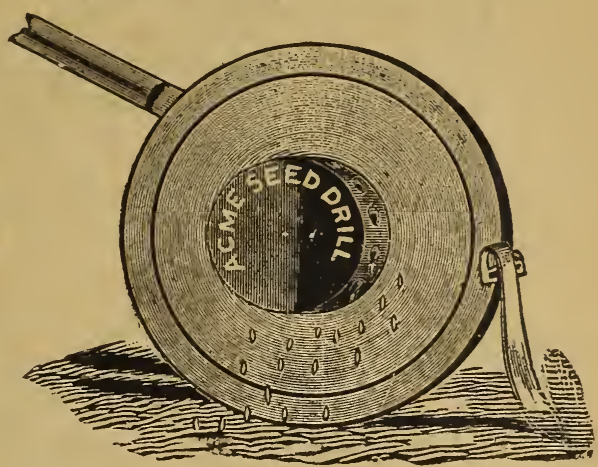

IF SENT BY EXPRESS, $\$ 1.00$.

A GARDEN SEED DRILL that will distribute Cabbage, Carrot, Celery, Bect, Lettuce, Radish and Turnip, and all such seeds with perfect regularity. It is utterly impassible for it to sow anything but accurately, doing the work as thoroughly as the costly machines, and will cover TEN TIMES the ground that can possibly be corered by hand. It is simple in construction, so easily understood that a child can be instantly taught to use it; so simply constructed it is impossible to get out of order.

\section{THEEUREKA}

\section{KITCHEN GARDEN AND} hot

It will sow and cover Beets, Cabbage, Carrots, Celery, Lettuce, Onions, Radishes, Spinach, Turnips, and all such seeds with the greatest regularity. The quality of work equals that done with the costly machines, and is infinitely better and faster than hand work.

\section{Have you a Kitchen Garden?}

Don't try to do without this little plariter another season. Your garden will smile approbation all through the season if you use the EUREKA.

\section{Have you a Kot-Bed?}

This drill you must have. It is the ONLY machine suited to sow in a hot bed. Sows up close to the sides in straight rows. Sows the smallest packet of seeds as well as a large bulk. This drill is not a toy, but a strong practicable machine that will last many years. Don't buy a similar machine, that has the opening plow in front of the machine. You can not get near the sides of a hot bed nor close up to the fence. Neither does it cover the seed. It will be an aggravation rather than a labor-saving machine as we sell.

By using this Drill you save seed, you save time, you stand in an upright position, the work is easy. you get a better stand, you get better plants.

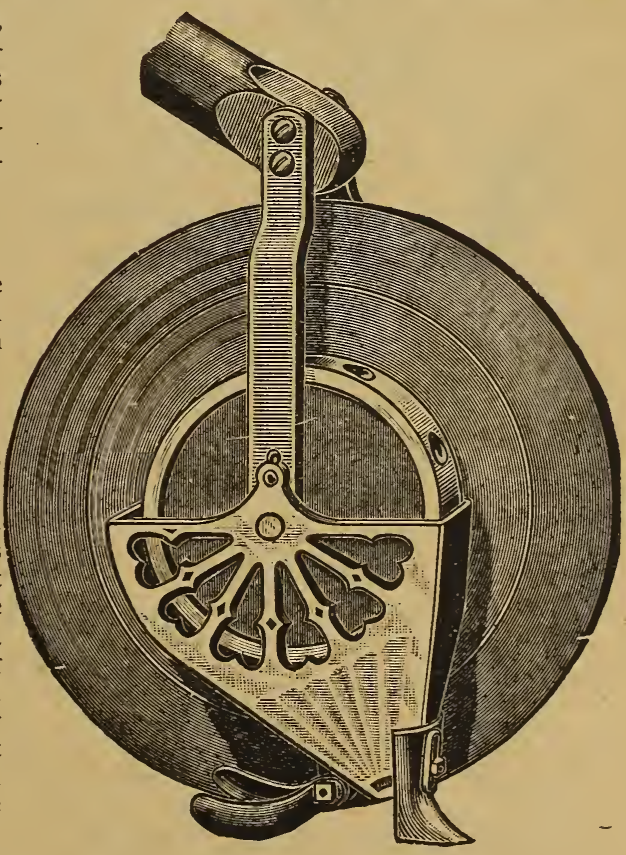

Price only $\$ 1.50$

If by express, buyer pays charges. 


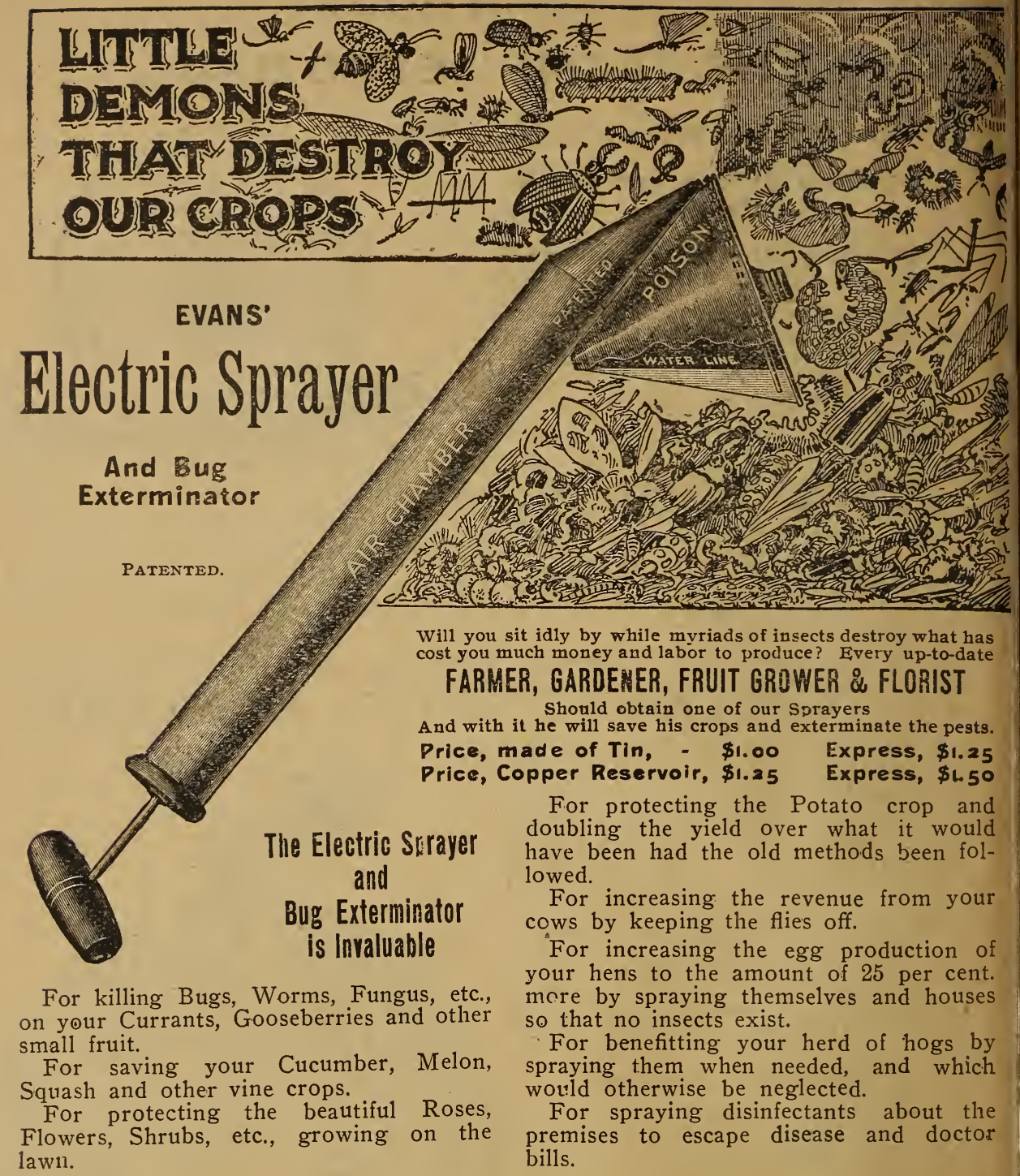

\section{Evans' Electric Sprayer and Bug Exterminator}

Is by long odds the Simplest, the Cheapest, the Lightest and the most Effective Machine on the market. THE ELECTRIC SPRAYER AND BUG EXTERMINATOR is a machine that will make anl save more money for Farmers, Gardeners, Florists, Orchardists, Stockmen and Poultrymen than any other machine they can buy, cost not considered.

PARIS GREEN is an excellent insecticile for the destruction of insects that eat foliage. Its use for the destruction of the potato beetle is familiar to all. It should be used in the proportion of one pound of the green to two hundred gallons of water, or a teaspoonful of the green to a bucket of water. The green should be first made into a thick paste with a little water, before being added to the full anicunt of water. Lime water added to the solution will prevent any damage to the foliage, and also make the mixture adhe:e better. Paris Green, $\frac{1}{4} 1 \mathrm{~b} ., 10 \mathrm{c}$; by. n:ail, $15 \mathrm{c}$; 1 1b., 35c.; by mail, $52 \mathrm{c}$. 


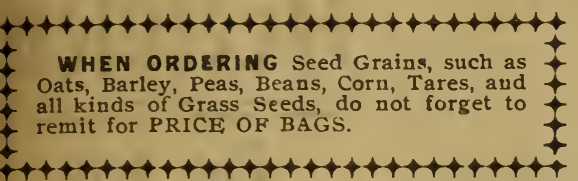

BIRD SEED, NOVELTIES, \&C.

\section{For Birds and Dogs.}

Following are a few of the different preparations we have in stock for

Dogs and Birds.

Parrot Food-Pkt., 15c.; by mail, 20c.

Parrot seed-Pkt., 15c.; by mail, 20c.

Bir1 Lime-Pkt., 25c.; by mail, 35c.

Cholera, or Roup Pills-Yer Box, 25c.; by mail, 30c.

Bird Bitters-Per bottle, 25c.

Mite Exterminator-Pkt., 25̌c.; by mail, $30 \mathrm{c}$.

Nestling Food-Pkt., 25c.; by mail, 30c.

Cuttle Bone (with patent holder) - 5c.; by mail, $10 \mathrm{c}$.

Moulting Pepper-Pkt., 25c.

Bird Manna-Pkt., 15c.; by mail, 20c.

Bird Cake-Pkt.. 5c.; by mail, 7c.

Birć Seed-Per 1b., 10c.; by mail, 15̃c.

Perches -5 cents each.

Swinging Perches -5 cents each.

Bathing Dishes-15c.

Bathing Dishes-10c.

Cups for Water and Seed-10c.

Nestling Hair-Per pkt., 5c.

Carary, best Sicily-Per lb., 10c.; by mail, $15 \mathrm{c}$.

Hemp, Russian, per 1b., 10c.; by mail, 15̌c.

Millet, Indian-Per 1b., 10c.; by mail, $15 \mathrm{c}$.

Rafe, German Summer-Per 1b., 10c.; by mail, $15 \mathrm{c}$.

Mixed Bird Seed (in sealed packets)-Per pkt., 10c.; by mail, $15 \mathrm{c}$.

Mocking Bird Food-Per pkt., 2̌̌c.; by mail, $30 \mathrm{c}$.

Nests for Birds-10c.

Mexican Salve-25c.; by mail, 30c.

Pcultry Powder (the great egg producer) $-25 \mathrm{c}$; ; by mail, $35 \mathrm{c}$

Dog Biscuits-10c. per lb.

Dug Soap-25c. per cake.

Mange Wash-25c. per bottle.

IVcrm Capsules-60c. per box.

Fish Food-25c. per box.

Bird Gravel (white or red)-Per pkt., 10c.

Canary Bird Whistlers-10c. each.; by mail, $15 \mathrm{c}$.

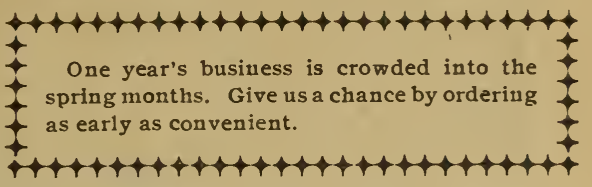

\section{SPECIAL SEEDS.}

Potato Onion Seed-Pkt., 5c.; oz., 30c. Shallot Onion Seed-Pkt., 5c.; oz., 30c. Mixed Gooseberry Seed, imported-Pkt., $5 \mathrm{c}$.

Mixed Currant Seed, imported-Pkt., 5c. Strawberry Seed-Pkt., 5c.

Raspberry Seed-Pkt., 5c.

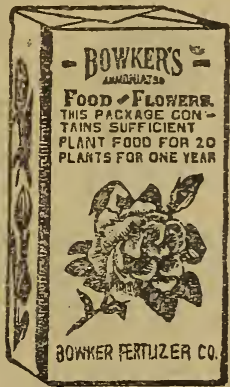

Bowker's Ammoniated Plant Food.

In packages, with directions for use, 25c. per pkt.; by mail, 35c. Large packets, 35c. per pkt.; by mail, 50c. A book, erititled "Window Gardening," given free with each packet of plant food.

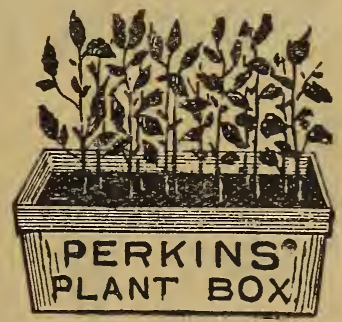

Plant Boxes.-Gardeners and others will find them very convenient and suitable for plants of all kinds. Per doz., 25c.; per $100, \$ 1.65$.

\section{GUANO.-Genuine Peruvian.}

A standard fertilizer throughout the enti:"e country, and in almost universal use. A weak solution, applied once or twice a week, is very beneficial for house plants. Per 1b., 10c.; by mail, $15 \mathrm{c}$.

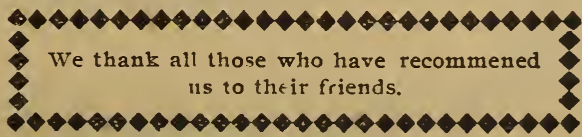




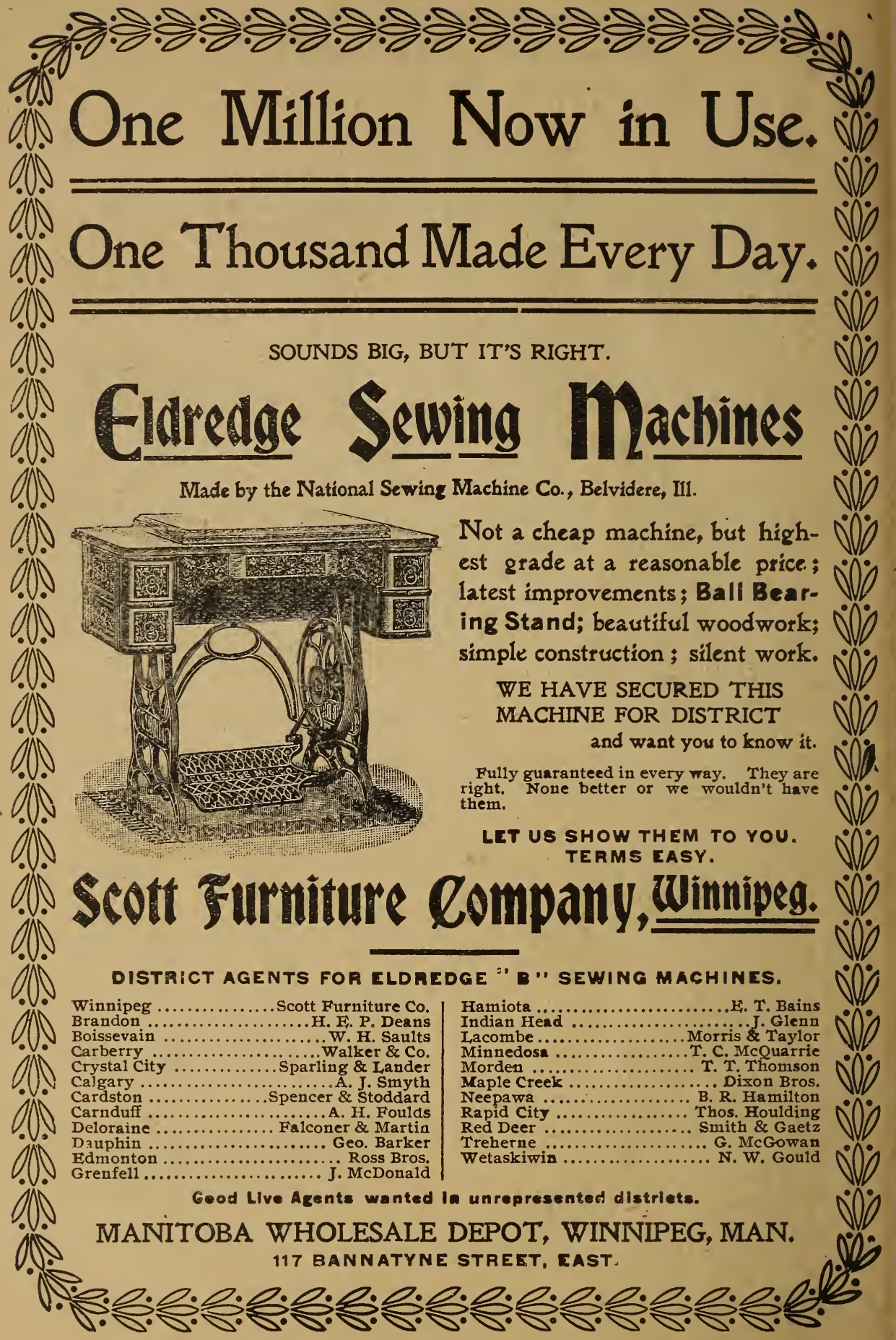




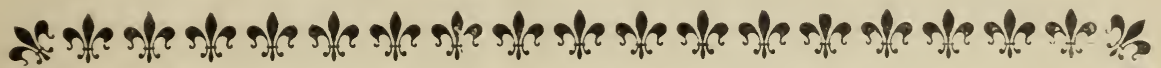
When Buying, Why Not Get the Best? 量

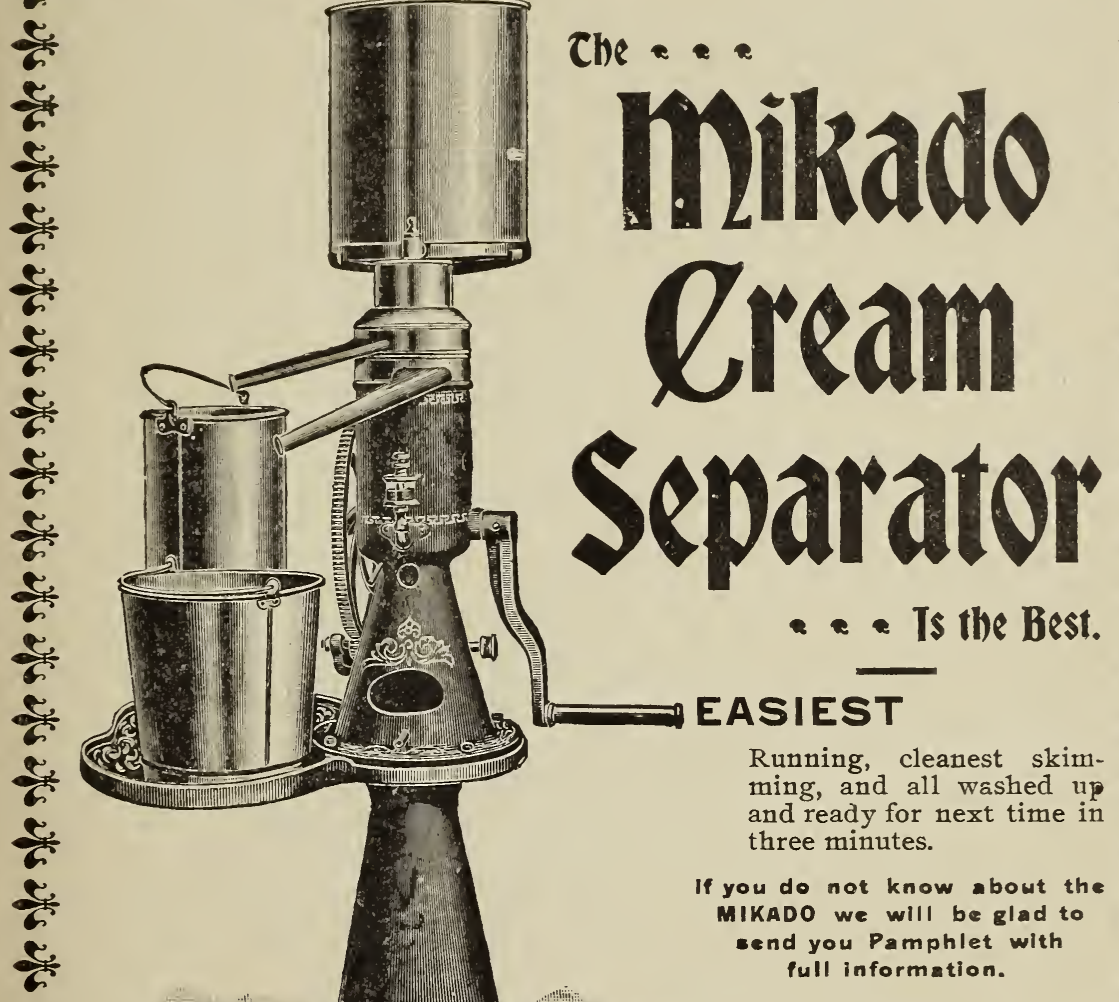
है कै कै

C. Brightside Farm, strathewen P.O., Man.

I wish to certify that I am thoroughly satisfied with the Mikado Cream Separator. I purchased it last summer, after a trial of two other much lauded machines, and I found r.he Mikado the eariest to operate, the easiest to clean, nd by far the simplest and cleanest ikimmer. is to durability, I am satisfi. d that it will last is long as anyone ran expect a machine to last: with the other inachines the operator would soon wear out. My little boy of six can easi!y run the Mikado; i stroug man would be required for one at least $\mathrm{cf}$ its rivals.-HENRY NEWMARCH. Any child can run ihe Mikado. and it has C. been run twice a day since I have had it.-H.M.
Prices and Terms to suit all Buyers

We have sold 1000 of these Separators in Manitoina alone, and print a few out of the many testimonials we have received :

Gentlemen, - I have been using one of your ${ }^{\mathrm{r}}$ Mikado Separators that I purchased from ycur agent at Lorlie for the past season. It is all that was recommended. Skims clean and easier than any other machine I have tried.- Yours truly, JoH N MORTON, Balcarris. The Cream Separator Co., Wiunipeg.

Dear Sirs, - I have been using a Mikado Separator for about three months, and am more than satisfied with the result. We have made fu.ly 30 per cent, more butter from its use than could be done in any other way. I believe, from experience and observation. the Mikado the best separator on the market to-day.-Yours truly, S. LARCOMBE, Birtle.

C. MANITOBA CREAM SEPARATOR CO.. Ltd., I5I Bannatyne ST., WINhIPEG.

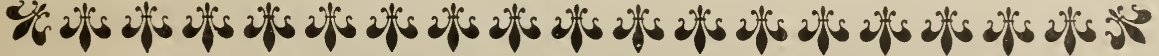




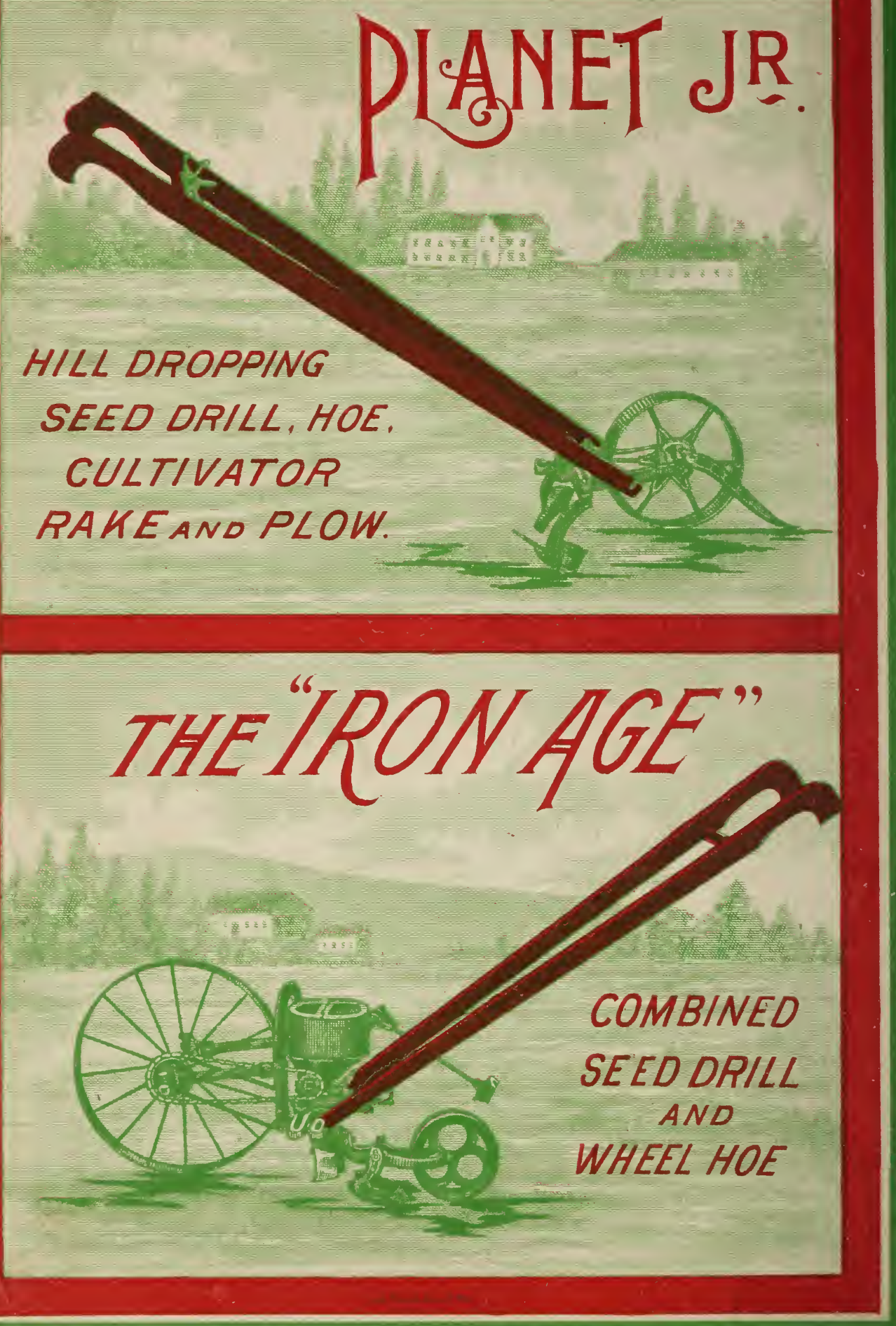

